\title{
Assessment of spatial variability of multiple ecosystem services in grasslands of different intensities
}

\section{Journal Article}

\section{Author(s):}

Le Clec'h, Solen; Finger, Robert (iD; Buchmann, Nina (D); Gosal, Arjan; Hörtnagl, Lukas (iD; Huguenin-Elie, Olivier; Jeanneret, Philippe; Lüscher, Andreas; Schneider, Manuel K.; Huber, Robert

Publication date:

2019-12

\section{Permanent link:}

https://doi.org/10.3929/ethz-b-000359568

\section{Rights / license:}

Creative Commons Attribution-NonCommercial-NoDerivatives 4.0 International

\section{Originally published in:}

Journal of Environmental Management 251, https://doi.org/10.1016/j.jenvman.2019.109372

\section{Funding acknowledgement:}

129866 - Farm-scale Methane Fluxes (FasMeF) (SNF)

136273 - CarboCount $\mathrm{CH}$ : Quantifying greenhouse gas fluxes and their sensitivity to climate variations: A case study in Central Europe and Switzerland (SNF)

154245 - Robust models for assessing the effectiveness of technologies and managements to reduce N2O emissions from grazed pastures (Models4Pastures) (SNF)

774124 - Developing SUstainable PERmanent Grassland systems and policies (EC) 


\title{
Assessment of spatial variability of multi- ple ecosystem services in grasslands of different intensities
}

Solen Le Clec'h ${ }^{1}$, Robert Finger ${ }^{1}$, Nina Buchmann ${ }^{2}$, Arjan S. Gosal ${ }^{3}$, Lukas Hörtnagl $\left.\right|^{2}$, Olivier HugueninElie $^{4}$, Philippe Jeanneret ${ }^{5}$, Andreas Lüscher ${ }^{4}$, Manuel K. Schneider ${ }^{4}$, Robert Huber ${ }^{1}$

1. ETH Zurich, Agricultural Economics and Policy, 8092 Zürich, Switzerland

2. ETH Zurich, Department of Environmental Systems Sciences, 8092 Zurich, Switzerland

3. Univrsity of Leeds, School of Geography, Leeds, UK

4. Agroscope, Forage Production and Grassland Systems, 8046 Zurich, Switzerland

5. Agroscope, Agroecology and Agriculture, 8046 Zurich, Switzerland

\begin{abstract}
Grasslands provide multiple Ecosystem Services (ES) such as forage provision, carbon sequestration or habitat provision. Knowledge about the trade-offs between these ES is of great importance for grassland management. Yet, the outcome of different management strategies on ES provision is highly uncertain due to spatial variability. We aim to characterize the provision (level and spatial variability) of grassland ES under various management strategies. To do so, we combine empirical data for multiple ES with spatially explicit census data on land use intensities. We analyzed the variations of five ES (forage provision, climate regulation, pollination, biodiversity conservation and outdoor recreation) using data from biodiversity fieldwork, experimental plots for carbon as well as social network data from Flickr. These data were used to calculate the distribution of modelled individual and multiple ES values from different grassland management types in a Swiss case study region using spatial explicit information for 17,383 grassland parcels. Our results show that (1) management regime and intensity levels play an important role in ES provision but their impact depends on the ES. In general, extensive management, especially in pastures, favors all ES but forage provision, whereas intensive management favors only forage provision and outdoor recreation; (2) ES potential provision varies between parcels under the same management due to the influence of environmental drivers, related to topography and landscape structure; (3) there is a trade-offs between forage provision and other ES at the cantonal level but a synergy between forage provision and biodiversity conservation within the grassland categories, due to the negative impact of elevation on both ES. Information about multiple ES provision is key to support effective agri-environmental measures and information about the spatial variability can prevent uncertain outputs of decision-making processes.
\end{abstract}

Keywords: ES provision; trade-offs; modelling; management strategies; land use; Switzerland

Highlights:

- Provision of multiple ES vary across management strategies/grassland categories 
- High variability of ES provision exists within grassland categories

- ES provision varies within grassland categories due to environmental factors 


\section{Introduction}

Grasslands cover approximately $40 \%$ of the Earth's land surface (Blair et al., 2014). These grasslands provide multiple Ecosystem Services (ES), ranging from provisioning services, regulating services and cultural services (Allan et al., 2015; Baldocchi et al., 2017; Harrison et al., 2010). The provision of these ES, and their interrelations, are highly affected by grassland management regimes and intensity (Jeanneret et al., 2007). Intensively used grasslands provide higher forage quantity and quality (Beckmann et al., 2019; Qi et al., 2018) while low-intensive grasslands are associated with higher biodiversity and related ES (Marini et al., 2008). In addition to management factors, environmental factors such as soil quality or elevation can affect ES provision (Feng et al., 2017; Wang et al., 2007).

Interrelationships among ES may be affected by the spatial allocation of grassland management regimes and intensities (Wu et al., 2017). Understanding the associations of ES coming from different grassland regimes and intensities in space would allow to identify areas in which production and biodiversity can be advanced jointly (Simons and Weisser, 2017). Moreover, leverage points can be identified where small management investments can yield substantial benefits (Bennett et al., 2009). Thus, better knowledge about relationships among ES in grasslands represents an important source for the design of natural resource management approaches in coupled human and natural systems (Kramer et al., 2017; Manning et al., 2018) and may contribute to counter ongoing land use intensification that reduces biodiversity (Allan et al., 2015; Birkhofer et al., 2018).

Research on ES associations (Mouchet et al., 2014) or bundles of ES (Spake et al., 2017) often treats grassland as one single type (e.g. Raudsepp-Hearne et al., 2010). This, however, is not always enough to be used for effective environmental management (Van der Biest et al. (2015) . Moreover, nearly all assessments to date do not consider ES provision on the plot which is ultimately the spatial level where farmers' decide on the management regime and intensity (Verhagen et al., 2018). This is of specific relevance for Europe, where agri-environmental schemes incentivize low intensive grassland use.

In this paper, we aim to contribute filling these gaps in the literature. We characterize the spatial provision of grassland ES in a multifunctional agricultural landscape under various grassland categories or management strategies (17,383 parcels of meadows or pastures, both at different intensities). We quantify the extent and variability if the provision of ES across grassland categories and quantify how variable the ES provision is within each category. More specifically, the research questions are: $i)$ What is the spatial variability of multiple grassland ES in a multifunctional agricultural landscape? and ii) What are the tradeoffs and synergies resulting from different grassland categories (based on management regimes and intensities)? A better understanding of ES associations resulting from different management regimes and intensities on parcel level can result in policies that are more efficient. The reminder of this paper is organized as follows. In the next Section, we describe the background of our study including the definition of grassland management regimes and intensities and of the spatial variability in ES provision and the policy context. In Section 3, we present the case study region, the outline of our methodology, followed by the data we used. In Section 4, we present the results of our analysis. Finally, we discuss the implications for agricultural policy.

\section{Background: Policy context and definitions of main concepts}

\subsection{Agri-environmental measures to support grassland ES}

Environmental goals have become an important pillar in European agricultural policies (Matthews, 2013). The maintenance of existing permanent grassland and the increase of grassland under lowintensity through agri-environmental measures are of specific relevance in this context. Permanent 
and low-intensive grasslands are expected to support many ES such as biodiversity conservation, carbon sequestration and landscape maintenance (Uthes and Matzdorf, 2013). However, the effectiveness of these measures is low (Pe'er et al., 2014) and grassland management plays an important role in further improving the environmental performance of the European Common Agricultural Policy (Navarro and López-Bao, 2018). In Switzerland many policy instruments incentivize low-intensive grassland use (Huber et al., 2017). Agri-environmental schemes for the extensive management of pastures and meadows help to conserve biodiversity in multifunctional agricultural landscapes (Herzog et al., 2005; Kampmann et al., 2012). Despite these efforts, the European and Swiss agricultural policy does not achieve its environmental targets. All these policy measures focus on the intensity of grassland management and its spatial allocation in the landscape. Thus, empirical based information about the trade-offs between grassland ES emerging from the plot based spatial variability and the choice of the grassland regime and intensity helps informing environmental management and the design of agri-environmental policy schemes in the European context (Engel, 2016).

\subsection{Associations of ES in grassland categories}

To clarify the underlying concepts used in this article, we define in the following paragraphs grassland categories, bundles of grassland ES, trade-offs and synergies, hotspots and coldspots as well as spatial variability of ES provision. Definitions on ecosystem service concepts are based on recent literature reviews by Mouchet et al. (2014), (Spake et al., 2017) and (Frei et al., 2018).

Grassland categories: Grassland can be managed with different regimes i.e., pastures or meadows, and with different intensity levels i.e., more or less fertilizer, number of cuts and or livestock density. These different grassland categories provide different levels of ES and biodiversity (Beckmann et al., 2019). More intensively used grasslands i.e., fertilized grassland with multiple cuts or a high stocking density provide higher forage quantity and quality (Beckmann et al., 2019; Qi et al., 2018). In contrast, low-intensive grasslands are expected to have higher biodiversity and related ES (Bengtsson et al., 2019; Habel et al., 2013; Marini et al., 2008). In this study, we considered five grassland categories: intensive, less intensive and extensive meadows as well as intensive and extensive pastures (see subsection 3.3).

Bundles of grassland ES: Bundles refer to "sets of ecosystem services that repeatedly appear together across space or time" (Raudsepp-Hearne et al., 2010). We define bundle as set of grassland ES that is provided repeatedly in space by our grassland categories. This is of fundamental importance since most of the European agricultural policies focus on the management of plots i.e., our grassland categories and not the management of landscapes or ecosystems. In line with Vannier et al. (2019), we argue that understanding ES associations beyond broad land-use or land-cover classes is key in gaining information for environmental management.

Trade-offs and synergies in grassland ES: Trade-offs "occur when the provision of one ES is reduced as a consequence of increased use of another ES" (Rodríguez et al., 2006). Synergies arise when the use of an ES simultaneously increases another ES (Spake et al., 2017). We here show the positive or negative association that exist across and within grassland categories and how they relate to underlying environmental factors. We focus on supply-supply relationship in different grassland categories and do not consider any further socio-economic aspects (see Mouchet et al., 2014 for other relationships).

Hotspots and coldspots: Hotspots and coldspots are areas providing, respectively, high and low amounts of one or several ES (Schulp et al., 2014).

Spatial variability: Spatial levels play an important role in the assessment of the relationships between ES (Qiu et al., 2018; Raudsepp-Hearne and Peterson, 2016; Simons and Weisser, 2017; Vallet 
et al., 2018). Underlying environmental factors can cause two types of variability. First, there is a spatial variability on the parcel level. Because of structural differences across or within parcels (e.g. soil types, elevation and average climatic conditions), the provision of ES such as grassland yields (Huguenin-Elie et al., 2017), pollination (Dauber et al., 2003) or plant species richness (Bruun, 2001) can differ substantially - even under similar management. Secondly, there is a spatial variability from the landscape composition and structure. For example, ES provision depends also on the characteristics of neighboring plots and surrounding landscape (Duflot et al., 2017; Hendrickx et al., 2007; Le Feon et al., 2010; Reitalu et al., 2009; Tscharntke et al., 2012) or recreational values (Colson et al., 2010; Edwards et al., 2012; Gul et al., 2006). We include both of these sources of variability in our analysis and define spatial variability as the positive or negative deviation from the mean ES provision per grassland category. Thus, grassland ES provision does not only depend on the management strategy but also on the underlying, spatially explicit environmental factors.

\section{Material and methods}

\subsection{Case study area}

We used the Swiss Canton of Solothurn as a case study region (Fig. 1). Solothurn is located in the northwest of Switzerland and covers an area of $791 \mathrm{~km}^{2}$. It presents a wide range of elevations from the plain created by the Aare River ( 277 m.a.s.l) to the foothills of the Jura massif (1,445 m.a.s.l). For centuries, agriculture has been the dominant land use in the canton. Agricultural land use is characterized by small-scale and diversified farming systems. Average farm size in the Canton of Solothurn is 23 ha and average parcel size is 0.9 ha, resulting in a heterogeneous pattern of croplands and grasslands. The predominant agricultural land use is permanent grasslands that covered around 165 $\mathrm{km}^{2}$, i.e., $67 \%$ of the agricultural area in 2015 , while rotational grasslands and cropland cover $14 \%$ and $32 \%$ of the cantonal area, respectively (FSO, 2015). 1,170 farms cultivated 17,383 parcels of permanent grasslands. Two third of these grasslands were meadows and one third was used as pastures. The dominance of grasslands in the region and the different spatial configurations among the canton makes it a highly suitable case study to analyze the provision of multiple grassland ES in a multifunctional agricultural landscape. 


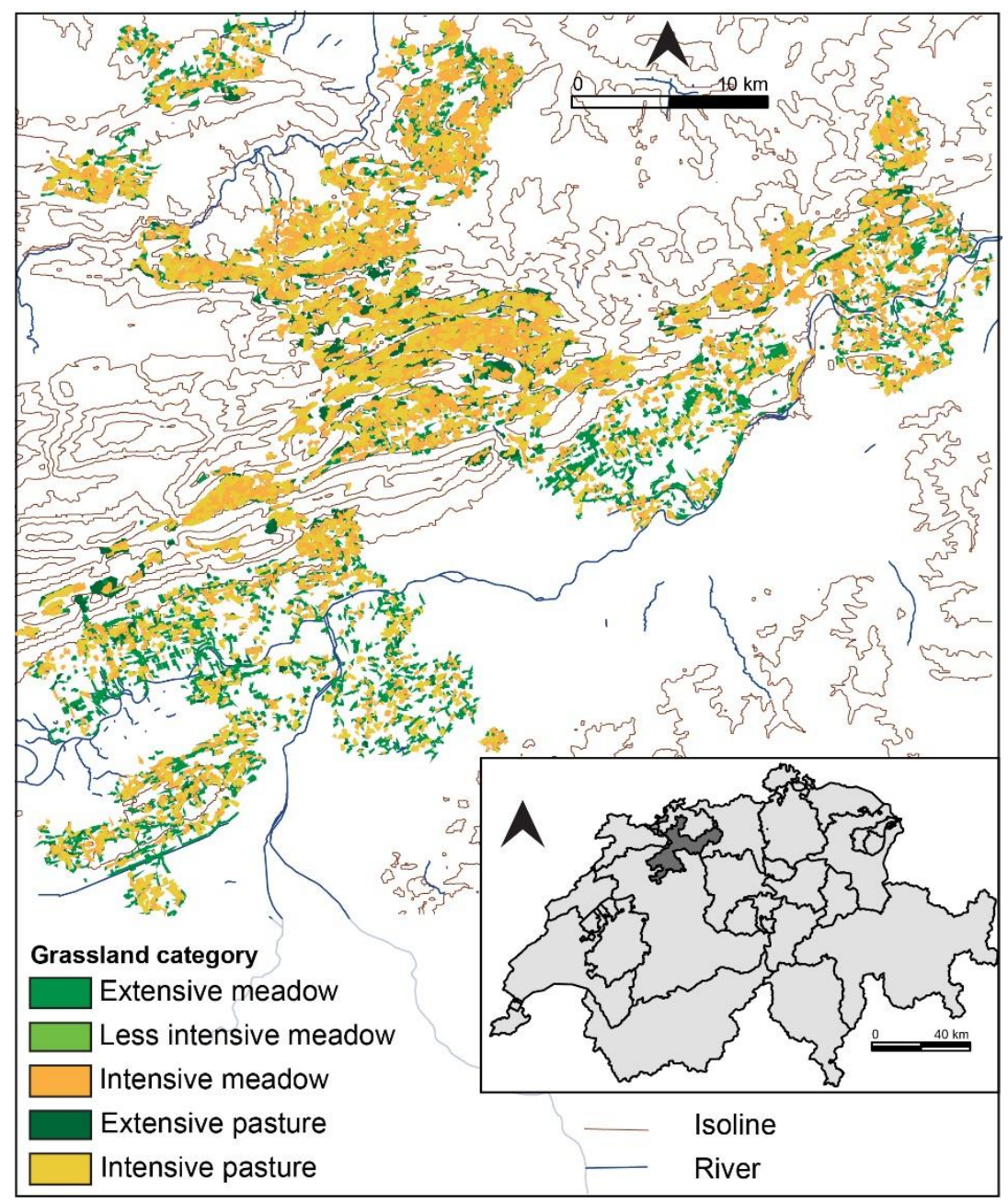

Figure 1: Location of the Canton of Solothurn in Switzerland and of the grassland parcels within the cantonal territory

\subsection{Methodological approach}

We proceeded in three methodological steps to characterize the provision of grassland ES from different grassland categories in a highly multifunctional agricultural landscape (Fig. 2). We focus on five indicators of ES provision (Table 2): yield (indicator of forage provision), Carbon (C) sequestration (composite indicator of climate regulation), bee species richness (indicator of pollination), vascular plant species richness (indicator of biodiversity conservation ${ }^{1}$ ) and the number of photos taken in grasslands (indicator of outdoor recreation).

First, we used data on ES provision from various data sources to (1, Fig. 2) implement statistical approaches that extrapolate ES provision to our study area from a set of explanatory variables (Table 3). These statistical approaches differ from one ES indicator to another depending on the number of observations, the identification of potential explanatory variables in the scientific literature, and the nature of the collected ES data. For $\mathrm{C}$ sequestration, bee and plant richness, the relationship to the explanatory variables including management characteristics and spatial variables (Table 3) was modeled and parameters estimated with regression analyses. For the yields and the number of photos,

\footnotetext{
${ }^{1}$ Biodiversity in grasslands can be considered a final ES sensu Mace et al. It provides important habitat services (de Groot et al. and can also been seen as a heritage value Rewitzer et al.
} 
we proceeded in one single step. For yields, we used the parameters of a regression that were estimated on the context of another study (Huguenin-Elie et al., 2017). We built a normal vector to map the number of photos.

Then, we assessed the spatial variability in the provision of the five individual ES by considering the difference between parcels in the different grassland categories (2, Fig. 2). We also considered the variation between the parcels and the mean provision under the same grassland categories. To do so we compared the modelled individual ES among grassland categories and we calculated the difference between the modelled individual ES provision of a specific parcel and the average ES provision of the grassland category of this parcel.

In the final step (3, Fig. 2), we used different statistical tools (Principal Components Analysis; PCA; and scoring) to analyze the provision of multiple grassland ES among and within the grassland categories. Analyses were done using the language and environment for statistical computing $R(R$ Development Core Team, 2018) ( R Core Team, 2018), with codes provided in the online Appendix. Below these three steps are explained in more detail.

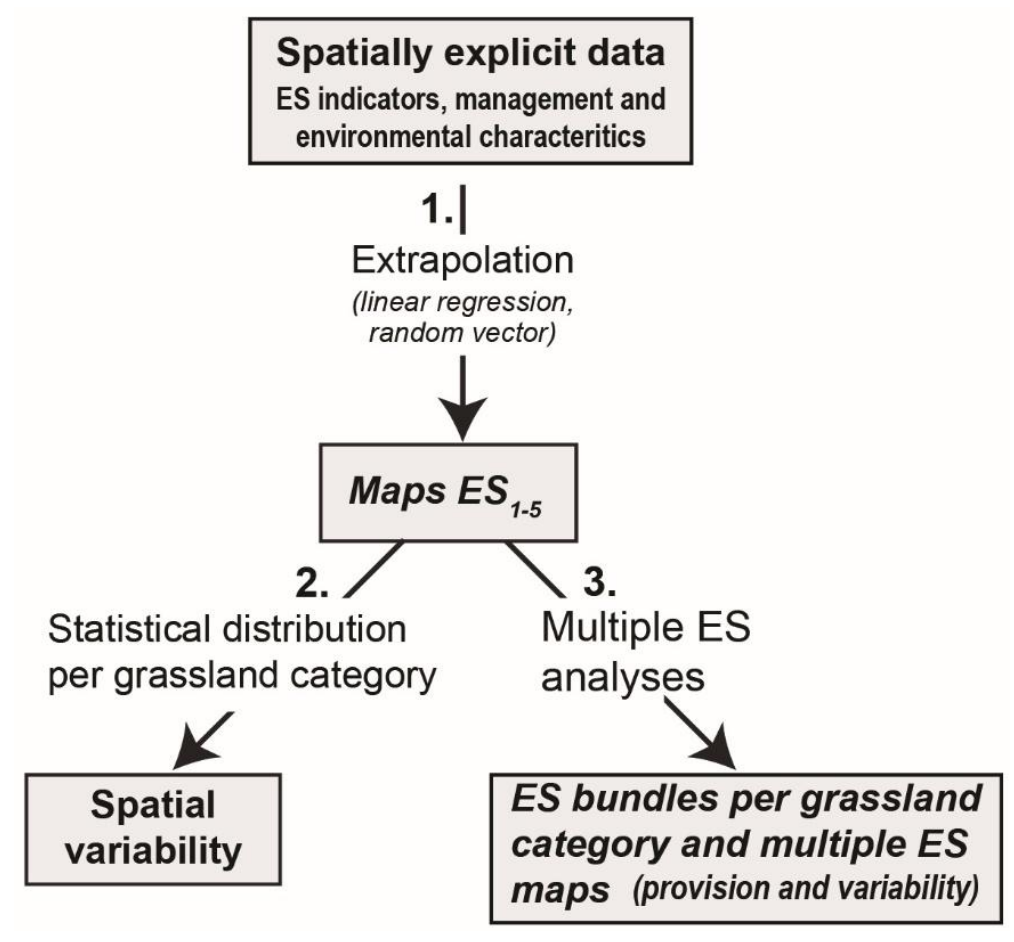

Figure 2. Methodological approach to assess the provision of grassland ES

\subsubsection{Regression analysis}

We implemented regressions for three individual ES indicators based on field data: $\mathrm{C}$ sequestration, bee and plant species richness. Such equations were necessary to identify the drivers of ES provision and to extrapolate ES values to the parcels of Solothurn based on the previously identified drivers. All these calculations were done at a parcel level.

\section{C sequestration}

To model the $\mathrm{C}$ sequestration (indicator of climate regulation), we considered direct measurements of the $\mathrm{CO}_{2}$ net ecosystem exchange (NEE) in combination with $\mathrm{C}$ import to the grassland through fertilization and $\mathrm{C}$ export through harvest. We estimated the three components based on our data and on literature review. 
In a first step, we estimated a linear function for the net $\mathrm{CO}_{2}$ exchange (NEE) (based on flux data collected at flux towers in temperate grassland sites across Europe; the names of the sites are given in Appendix 1, see also section 3.4) for each parcel using three explanatory variables: management regime, management intensity and elevation as explanatory variables (Table 3; Eq. 1a). A negative NEE meant a CO2 uptake whereas a positive NEE reflected a loss. We selected the final model, through a variable selection procedure and estimated the parameters $\left(\propto_{0}, \propto_{1}, \propto_{2}\right.$ and $\left.\propto_{3}\right)$. We employed Mallows' Cp as a goodness-of-fit measure (Mallow, 1973) to select best combination and identify the components of the management and of the landscape that affect the ES provision, and avoid noise and collinearity ${ }^{2}$. Such procedures are recommended to proceed to spatial extrapolations (Authier et al., 2017) and widely used in geostatistics (Hoeting et al., 2006).

$N E E=\propto_{0}+\propto_{1} \cdot$ Regime $+\propto_{2} \cdot$ Intensity $+\propto_{3} \cdot$ Elevation

with, $N E E$, net ecosystem exchange ( $\mathrm{C} / \mathrm{ha} /$ year) and Elevation, its average elevation (in $\mathrm{m}$ ).

In a second step, we estimated the carbon input ( $C_{\text {input }}$ through fertilization; Eq $\left.1 \mathrm{~b}\right)$. The $C$ input was calculated from two variables: the amount of recommended nitrogen fertilizers $(\mathrm{N})$ spread on the parcel and the $\mathrm{C} / \mathrm{N}$ ratio in the fertilizers. The amount of $\mathrm{N}$ fertilizers was based on the recommendation of fertilization by Huguenin-Elie et al. (2017). The $\mathrm{C} / \mathrm{N}$ ratio of 6.1 was estimated from the data available for the observation sites used to model the NEE (flux towers across European grasslands) based on the amount of $\mathrm{N}$ and $\mathrm{C}$ contained in the organic fertilizers. The amount of recommended fertilizers applied depended on the yields (see below; eq. 3). For more information, see Appendix 3.

$C_{\text {input }}=N \cdot 6.1 \cdot$ Yield

with, $N$, the recommended amount of nitrogen per unit yield (in $\mathrm{t} / \mathrm{t} \mathrm{DM}$ ), Yield, the estimated yield ( $\mathrm{t}$ $\mathrm{DM} / \mathrm{ha})$.

In a third step, we estimated the $C$ exported out of the grassland systems ( $C_{\text {harvest }_{p}}$ through harvesting; Eq. $1 \mathrm{c}$ and $1 \mathrm{~d}$ for meadows and pastures respectively). Due to the lack of data for the meadows, we used IPCC guidelines to estimate $C$ export as 0.47 of the dry biomass (IPCC, 2006). For the pastures, we had information about the $C$ exported for one of the Swiss observation sites ${ }^{3}$. We built a linear model to link the yields and the $\mathrm{C}$ exported annually at this observation site and estimated the $\partial_{0}$ and $\partial_{1}$ parameters.

For the meadows: $C_{\text {export }}=0.47 \cdot$ Yield

For the pastures: $C_{\text {export }}=\partial_{0}+\partial_{1} \cdot$ Yield

\section{Vascular plant and bee species richness}

We also implemented regression analyses to model bee and vascular plant species richness (indicators of pollination and biodiversity conservation, respectively; Eq. 2). The models were build using observed data and a wider set of explanatory variables (Table 3): management regime and intensity, information about the landscape composition (i.e., size of the parcel, distance to the forest, patch richness, Simpson diversity of the landscape) and pedo-topographical features (i.e. elevation and slope).

Species richness $=\gamma_{0}+\gamma_{X} \cdot X$,

\footnotetext{
${ }^{2}$ We compared the results of the variable selection procedure using BIC and Mallow's $\mathrm{Cp}$. When the results were different, we performed a cross-validation procedure. This procedure demonstrated Mallow's Cp to have a better goodness of fit for our data.

${ }^{3}$ Site of Chamau, for seven cattle grazing episode between 2001 and 2014.
} 
with Species richness, the richness in either bees or plants (i.e. number of species), $X$ a set of explanatory variables about the management, its environmental characteristics and the characteristics of the surrounding landscape of the considered parcel (Table 3$)$. We estimated parameters $\left(\gamma_{0}\right.$ and $\left.\gamma_{1}\right)$ of the final model.

\subsubsection{Extrapolation of ES values to the parcels of Solothurn}

Forage provision

To extrapolate the yield (indicator of forage provision) for each parcel in our case study region, we used the parameters of the linear models estimated by Huguenin-Elie et al. (2017). Yields for all grasslands were estimated depending of their regime, the intensity level considered as $\left(\beta_{0}\right.$ and $\left.\beta_{1}\right)$ and elevation (Elevation; Table 3 and Equation 3 ). Following Huguenin-Elie et al. (2017), below 500 m.a.s.l, yield estimations are equivalent to those calculated at 500 m.a.s.l. Above 500 m.a.s.l, elevation was used as a continuous quantitative variable. We also account for soil quality differences across space. The values presented above represent highest soil suitability (class one of a five-class typology). We used a correction factor $\left(c f_{p}\right)$ to adjust yield estimates according to the information about soil suitability for agricultural production for each parcel (FOAG, 2005). For lower soil suitability classes (class 2 to class 5 ), the maximum yield is reduced by $5 \%$ to $20 \%$, respectively, representing assumptions made in other Swiss case studies (Mosimann, 2005).

Yield $=\left(\beta_{0}-\beta_{1} \cdot\right.$ Elevation $) \cdot c f$,

with Yield, the estimated yield ( $\mathrm{t}$ DM/year) and Elevation its average elevation (in $\mathrm{m}$ )

\section{C sequestration}

To map $\mathrm{C}$ sequestration, we extrapolated the NEE, the $\mathrm{C}$ input (through fertilization) and the $\mathrm{C}$ export (through harvest) to the study area by applying Equations $1 \mathrm{a}, 1 \mathrm{~b}, 1 \mathrm{c}$ and $1 \mathrm{~d}$ to the parcels of Solothurn. Finally, we calculated $C$ sequestration for each parcel by accounting for NEE, $C$ input and $C$ export (Eq. 4). To do so, we applied the Equation 4, following Chang et al. (2015) to the parcels of grassland of Solothurn. A high $\mathrm{C}$ sequestration was the result of high $\mathrm{C}$ intakes (photosynthesis and/or $\mathrm{C}$ in fertilization) and low $\mathrm{C}$ losses ( $\mathrm{C}$ content in harvests). For that reason, we considered the opposite of the NEE, as a negative NEE corresponded to a high $\mathrm{CO}_{2}$ uptake of the grassland system.

$C_{\text {seq }}=-N E E+C_{\text {input }}-C_{\text {export }}$

with $C_{\text {seq, }}$ the $C$ sequestration (t C/ha/year), NEE, net ecosystem exchange (t $\mathrm{C} /$ ha/year), $C_{\text {input }}$ the $C$ imported in the system through fertilization ( $\mathrm{t} C /$ ha/year) and $C_{\text {export }}$, the $C$ exported from the system through harvesting (t $\mathrm{C} / \mathrm{ha}$ /year).

\section{Plant and bee species richness}

To extrapolate the bee and plant species richness, we applied the models that were estimated from the observed data to the parcels of Solothurn (Eq. 2).

\section{Number of photos}

To extrapolate the number of photos (indicator of outdoor recreation), we used the photos taken in grassland in the Canton of Solothurn posted on Flickr. We assumed that all grasslands of a specific management strategy (i.e. the same grassland category) might provide similar outdoor recreation, as studies showed the influence of land uses on cultural ES, including outdoor recreation (LindemannMatthies et al., 2010). However, the elevation affects the provision of cultural services (Schirpke et al., 2017) and we considered here lowlands $(<800 \mathrm{~m}$ m.a.l.s.) and highlands ( $>=800 \mathrm{~m}$ m.a.l.s.) to model the outdoor recreation. We thus first subdivided the five grasslands categories into ten categories, using these two elevational levels. We extracted the number of photos taken in each of the 
ten grassland categories and years, between 2008 and 2017. Second, we built 'normal vectors' to extrapolate the number of photos. A 'normal vector' is defined by three parameters: its length, its average value and its standard deviation. We built ten normal vectors whose lengths corresponded to the number of parcels of the grasslands categories (management regimes, intensity and elevation levels). The average value of the ten normal vectors corresponded to the number of photos taken in 2017 per grassland category and elevation class. Vector standard deviations corresponded to the standard deviation of the time series per grasslands category and elevation class.

\subsubsection{Estimating spatial variability in ES provision}

The spatial variability of ES provision between parcels under the same grassland category in our study can originate from spatially explicit environmental factors (Parcel; Table 1) or on the characteristics of their surrounding landscape (landscape structure; Table 1). The spatial variability between parcels under the same grassland category originates from the variation in the primary data sources for each of the grassland categories. This type of variation was considered for all ES. Variations due to the landscape structure was considered for bee and plant species richness ${ }^{4}$.

To illustrate the range of the spatial variability on a landscape level, the modelled values can be presented in a density function showing the distribution curve of ES per grassland category in our case study region. In addition, we identified the spatial variability by calculating the standard deviation of the individual ES under the same grassland category.

To identify the spatial variability within bundles, we calculated the variation $\Delta$ for each individual ES in each parcel. This variation $\Delta$ corresponded to the difference between the expected (modelled) ES $\widehat{E S}$ value for a given parcel and the mean value of its corresponding grassland category $\overline{E S_{G}}$, (Eq. 5).

$$
\Delta=\widehat{E S}-\overline{E S_{G}}
$$

Table 1. Sources of spatial variability for ES in parcels under the same grassland category. "Not available" means that consideration of the uncertainty was not possible with the dataset we used

\begin{tabular}{|l|l|l|}
\hline \multirow{2}{*}{ ES (indicator) } & \multicolumn{2}{|c|}{ Spatial variability } \\
\cline { 2 - 3 } & Parcel & Landscape structure \\
\hline Forage provision (yield) & Considered (elevation and soil) & Not available \\
\hline C sequestration (composite variable) & Considered (elevation) & Not available \\
\hline Pollination (bee richness) & Considered (diverse environmental factors) & Considered \\
\hline Biodiversity conservation (plant richness) & Considered (diverse environmental factors) & Considered \\
\hline $\begin{array}{l}\text { Outdoor recreation (photos taken in grass- } \\
\text { land area) }\end{array}$ & Considered (elevation) & Not available \\
\hline
\end{tabular}

\subsubsection{Identification of ES trade-offs, bundles and multiple ES maps}

To characterize the provision of multiple ES, we performed five analyses at the parcel level based on the extrapolated data. First, we analyzed the trade-offs and synergies between the five individual ES indicators by performing a PCA. We used the extrapolated ES values for the 17,383 parcels (individuals) and all five individual ES indicators (variables), independent of management regime or management intensity. The PCA allowed us to determine the relationships among the five individual ES indicators. A constraint PCA allowed us to reveal the differences in terms of multiple ES provision between the five grassland categories, at the cantonal level and an s-class analysis was used to represent each category by its center of gravity and the links between each parcel and its specific grassland category.

\footnotetext{
${ }^{4}$ We did not find reliable data that accounted for the influence of landscape structure on the variation of yield, $C$ sequestration and number of photos.
} 
Second, we performed five PCAs, one per grassland category, on the extrapolated ES values for the parcels (individuals) and all five individual ES indicators (variables). The number of statistical individuals depended on the number of parcels under the considered grassland category. The PCAs allowed us to bundles of ES that determine the relationships i.e., positive and negative associations among the five individual ES indicators between parcels under the same management. We projected the environmental factors, such as the elevation, as supplementary variables to understand their role in the multiple ES provision within the grassland categories.

Third, we analyzed the bundles induced by the management, by characterizing the multiple ES provision for each grassland category. For each grassland category and each ES indicator, we calculated the average modelled ES values $\overline{(E S)}$ and performed a PCA on the new dataset. Next, for each grassland category and each ES indicator, we calculated the average of the standard deviation $\overline{(s d)}$ of the modelled ES values and performed another PCA on the new dataset. From the two PCAs, we extracted the factorial coordinates of the projected variables (standardized $\overline{E S}$ and standardized $\overline{s d}$ ) and plotted them per intensity of management, for meadows and pastures separately, to get bundles of ES within the grassland categories. These bundles combine both average ES provision and its variability.

Fourth, we mapped the ES hotspots at the parcel level through the calculation of an overall score (Eq. 6). We combined all individual-ES maps into an overall aggregated ES score based on the statistical distribution of each ES indicator (Lavorel et al., 2011; Le Clec'h et al., 2016; Maes et al., 2012). This overall score represents equal weighting across all individual ES indicators (Score). We transformed each of the five individual ES indicator into an ordinal score $\left(Q_{E S},\right)$ from one to four, based on the quartiles (Petter et al., 2013) and summed up the five individual scores into an overall score.

Score $=\sum Q_{E S}$

Eq. 6

Finally, we mapped the variation of the overall ES provision between parcels under the same grassland category at the parcel level. To do so, we standardized the individual variations $\Delta$ known for each parcel (see 3.2.2 for calculation of the spatial variability $\Delta$ in each parcel and each ES indicator). To standardize these variations $\Delta$, we identified the minimal and maximal variation of each ES indicator for all parcels of the corresponding grassland category, $\min \left(\Delta_{E S}\right)$ and $\max \left(\Delta_{E S}\right)$. We used these minimal and maximal variations to get a normalized value for each ES, comprised between -1 and 1 . Finally, we summed up the five individual variation $\Delta$ into an overall variation $\Delta_{\text {total }}$ (Eq. 7).

$$
\Delta_{\text {total }_{p}}=\sum_{E S}\left(2 *\left(\frac{\Delta_{E S_{p-}} \min \left(\Delta_{E S}\right)}{\max \left(\Delta_{E S}\right)-\min \left(\Delta_{E S}\right)}\right)-1\right)
$$

\subsection{Data}

\section{ES and their indicators}

We studied forage provision through annual grassland yields. We followed the study by HugueninElie et al. (2017) which combined parcel characteristics with empirical yield estimations. We studied climate regulation through the annual $\mathrm{C}$ sequestration based on net $\mathrm{C}$ exchange (NEE) as well as $\mathrm{CO}_{2}$ imported and exported in the grassland system through fertilization and harvesting. We used in-situ measurements for a subset of grassland sites across Europe, the FLUXNET2015 dataset, for the calculation of climate regulation services (Pastorello et al., 2017). Bee richness is an important indicator to study pollination because almost all bees are pollinators and grasslands constitute an important habitat for them (Hudewenz et al., 2012; Meyer et al., 2017; Nogué et al., 2016; Rogers et al., 2014). In addition, we studied biodiversity conservation through vascular plant richness in each of the grass- 
land categories (Lüscher et al., 2016). We used the Biobio dataset for the calculation of biodiversity conservation and pollination services (Lüscher et al., 2016). Finally, to account for outdoor recreation, we used the number of geo-tagged photographs in different grassland categories per square kilometer and per year posted on Flickr. More information about the data sources and the development of the indicators can be found in Appendix 1.

Table 2. ES indicators and data sources

\begin{tabular}{|c|c|c|c|c|c|c|}
\hline $\begin{array}{l}\text { ES Catego- } \\
\text { ry }\end{array}$ & ES & Indicator & Unit or range & $\begin{array}{l}\text { Data collec- } \\
\text { tion }\end{array}$ & Sources & Type of data \\
\hline Provisioning & $\begin{array}{l}\text { Forage } \\
\text { production }\end{array}$ & Yield & $\begin{array}{l}\text { Ton of Dry Mat- } \\
\text { ter per hectare ( } \\
\text { ha } \mathrm{y}^{-1} \text { ) }\end{array}$ & & $\begin{array}{l}\text { Huguenin-Elie } \\
\text { et al., } 2017\end{array}$ & $\begin{array}{l}\text { Modelled data } \\
\text { based on field } \\
\text { measurements }\end{array}$ \\
\hline \multirow[b]{2}{*}{ Regulating } & $\begin{array}{l}\text { Climate } \\
\text { Regulation }\end{array}$ & $\begin{array}{l}\text { C sequestration } \\
\text { (composite } \\
\text { variable) }\end{array}$ & $\begin{array}{l}\text { Ton of } C \text { per } \\
\text { hectare and year } \\
\left(\mathrm{t} C{\left.\text { ha } \mathrm{y}^{-1}\right)}\right.\end{array}$ & $\begin{array}{l}\text { Half-hourly } \\
\text { measured } \\
\text { fluxes, availa- } \\
\text { ble for several } \\
\text { years }\end{array}$ & FLUXNET2015 & $\begin{array}{l}\text { Field meas- } \\
\text { urements at } \\
17 \text { European } \\
\text { flux towers }\end{array}$ \\
\hline & Pollination & Bee richness & $\begin{array}{l}\text { Number of spe- } \\
\text { cies }\end{array}$ & $\begin{array}{l}\text { Aerial netting } \\
\text { collection } \\
\text { along a } 2 \times 100 \\
\mathrm{~m} \text { transect on } \\
\text { three dates } \\
\text { during good } \\
\text { weather condi- } \\
\text { tions in } 2010\end{array}$ & $\begin{array}{l}\text { Lüscher et al., } \\
2016\end{array}$ & $\begin{array}{l}\text { Field meas- } \\
\text { urements from } \\
\text { the canton of } \\
\text { Obwalden } \\
\text { (Switzerland) }\end{array}$ \\
\hline \multirow[t]{2}{*}{ Cultural } & $\begin{array}{l}\text { Biodiversity } \\
\text { conservation }\end{array}$ & Plant richness & $\begin{array}{l}\text { Number of spe- } \\
\text { cies }\end{array}$ & $\begin{array}{l}\text { One survey of } \\
10 \mathrm{~m} \times 10 \mathrm{~m} \text { in } \\
2010\end{array}$ & $\begin{array}{l}\text { Lüscher et al., } \\
2016\end{array}$ & $\begin{array}{l}\text { Field meas- } \\
\text { urements from } \\
\text { the canton of } \\
\text { Obwalden } \\
\text { (Switzerland) }\end{array}$ \\
\hline & $\begin{array}{l}\text { Outdoor recrea- } \\
\text { tion }\end{array}$ & $\begin{array}{l}\text { Photos taken in } \\
\text { grassland area }\end{array}$ & $\begin{array}{l}\text { Number of pho- } \\
\text { tos between } \\
2007 \text { and } 2017\end{array}$ & $\begin{array}{l}17,979 \text { photo- } \\
\text { graphs posted } \\
\text { on Flickr }\end{array}$ & $\begin{array}{lr}\text { Flickr (photo } \\
\text { sharing social } \\
\text { media website) }\end{array}$ & $\begin{array}{l}\text { Data collected } \\
\text { from the Inter- } \\
\text { net }\end{array}$ \\
\hline
\end{tabular}

\section{Data for the spatial models}

To administer the payments of different grassland categories, the Swiss Cantons collect spatially explicit census data on grasslands (and croplands) (GELAN, 2018). The census data comprise five categories of grassland management. These are based on two management regimes (pastures or meadows) and three intensity levels: extensive, less intensive and intensive meadows as well as extensive and intensive pastures (see Appendix 2 for details).

In addition, we used data on the biophysical characteristics of the parcels and of their surrounding landscape. Data about elevation were extracted from a Digital Elevation Model (DEM; 90m spatial resolution; Jarvis et al. (2008)) and slope (in \%) was derived from the DEM. Information about the soil was published by the FOAG (2005). It constitutes a five-class typology based on the slope, the exposition and the nature of the bedrock. Information about the landscape composition and structure were derived from Corine Land Cover data, using landscape ecology metrics (http://land.copernicus.eu/global/). All information was extracted at the parcel level by calculating the average elevation and slope and selecting the soil class that covered most of the parcel.

Table 3. Data used for the spatial modelling

\begin{tabular}{|c|c|c|c|}
\hline \multicolumn{2}{|r|}{ Data } & Description & Source \\
\hline \multirow{3}{*}{ Management } & Regime & 2 categories: Meadow or pasture & \multirow{3}{*}{$\begin{array}{l}\text { Census data, Canton } \\
\text { of Solothurn }\end{array}$} \\
\hline & Intensity & $\begin{array}{l}2 \text { to } 3 \text { levels: intensive, less intensive (for the meadows only) } \\
\text { and extensive }\end{array}$ & \\
\hline & Area & Size of the parcel (ha) & \\
\hline \multirow{4}{*}{$\begin{array}{l}\text { Biophysical } \\
\text { factors }\end{array}$} & Elevation & Average elevation of the parcel (m) & \multirow{2}{*}{$\begin{array}{l}\text { Aster Digital Elevati- } \\
\text { on Model }\end{array}$} \\
\hline & Slope & Average slope of the parcel (\%) & \\
\hline & Soil & $\begin{array}{l}\text { Suitability for agricultural production. Five-classes typology } \\
\text { based on slope, exposition and nature of bedrock }\end{array}$ & FOAG, 2005 \\
\hline & Simpson diversity & Index of landscape diversity & Corine Land Cover, \\
\hline
\end{tabular}




\begin{tabular}{|l|l|l|l|}
\hline & Patch Richness & Index of landscape fragmentation & 2012 \\
\cline { 2 - 3 } & Distance to forest & Distance to closest patch of forest $(\mathrm{m})$ & \\
\hline
\end{tabular}

\section{Results}

\subsection{Identifying relevant drivers for modelling ES}

Models differed in their ability to predict a given indictor but also in the number and nature of the variables selected (Table 4). Regime and intensity affect all ES indicators and their impact depends on the ES indicator. Elevation was an important driver of most of the ES indicators as well. It was negatively correlated with yield, NEE and plant species richness. For bee and plant richness, slope was also significant and negatively correlated. In addition, distance to forests was relevant to model bee species richness and was negatively correlated to the ES indicator, meaning that bee species richness increased with a decreasing distance to forest patches.

Table 4. Outputs of the statistical modelling: $R^{2}$, selected variables for each indicator. NA means that the model was applied but not built with primary data in the context of our study (yield) or that a regression method was not applied (outdoor recreation). Equations of the final models and coefficient estimates can be found in Appendix 4

\begin{tabular}{|c|c|c|c|c|c|c|}
\hline ES & $\begin{array}{l}\text { ES indica- } \\
\text { tor }\end{array}$ & Unit & $\begin{array}{l}\text { Tested exploratory varia- } \\
\text { bles }\end{array}$ & $\begin{array}{l}\text { Final model (signif- } \\
\text { icant explanatory } \\
\text { variables) }\end{array}$ & $\mathbf{R}^{2}$ & $\mathbf{N}$ \\
\hline $\begin{array}{l}\text { Forage provi- } \\
\text { sion }\end{array}$ & Yield & $\begin{array}{l}\mathrm{t} \text { of } \mathrm{DM} / \\
\mathrm{ha}\end{array}$ & $\begin{array}{l}\text { NA (Huguenin-Elie et al., } \\
\text { 2017) }\end{array}$ & $\begin{array}{l}\text { Regime, intensity, } \\
\text { elevation, soil }\end{array}$ & $\begin{array}{l}\text { See } \\
\text { notes }^{5}\end{array}$ & \\
\hline \multirow{3}{*}{$\begin{array}{l}\text { Climate regula- } \\
\text { tion }\end{array}$} & NEE & t C ha ${ }^{-2} y^{-1}$ & Regime, intensity, elevation & $\begin{array}{l}\text { Regime, intensity, } \\
\text { elevation }\end{array}$ & 0.4 & 83 \\
\hline & $\mathrm{C}_{\text {input }}$ & tC ha ${ }^{-2} y^{-1}$ & NA & Yield and $\mathrm{N}$ fertilizer & NA & NA \\
\hline & $\mathrm{C}_{\text {export }}$ & t C ha ${ }^{-2} y^{-1}$ & NA & Yield & $\begin{array}{l}0.99 \\
\text { (pasture) }\end{array}$ & $\begin{array}{l}7 \text { (pas- } \\
\text { ture) }\end{array}$ \\
\hline Pollination & Bee richness & $\begin{array}{l}\text { Number } \\
\text { of species }\end{array}$ & $\begin{array}{l}\text { Regime, intensity, elevation, } \\
\text { slope, distance to forest, } \\
\text { patch richness and Simpson } \\
\text { index }\end{array}$ & $\begin{array}{l}\text { Regime, intensity, } \\
\text { distance to forest, } \\
\text { slope }\end{array}$ & 0.41 & 53 \\
\hline $\begin{array}{l}\text { Biodiversity } \\
\text { conservation }\end{array}$ & $\begin{array}{l}\text { Plant rich- } \\
\text { ness }\end{array}$ & $\begin{array}{l}\text { Number } \\
\text { of species }\end{array}$ & $\begin{array}{l}\text { Regime, intensity, elevation, } \\
\text { slope, distance to forest, } \\
\text { patch richness and Simpson } \\
\text { index }\end{array}$ & $\begin{array}{l}\text { Regime, intensity, } \\
\text { elevation, slope }\end{array}$ & 0.75 & 53 \\
\hline $\begin{array}{l}\text { Outdoor recre- } \\
\text { ation }\end{array}$ & Photographs & $\begin{array}{l}\text { Number } \\
\text { of photos }\end{array}$ & $\begin{array}{l}\text { NA - application of a normal } \\
\text { vector }\end{array}$ & $\begin{array}{l}\text { Regime, intensity, } \\
\text { elevation }\end{array}$ & NA & NA \\
\hline
\end{tabular}

\subsection{Modelling spatial ES provision}

Based on the drivers of ES provision (Table 4), we modelled and extrapolated the five ES indicators to the parcels of the study area (Figure 3; Maps derived from the extrapolations are presented in Appendix 4). Kruskal-Wallis tests revealed that there were significant differences between the means of the ES indicators among grassland categories (Table A6). Modelled yields were significantly higher in meadows, compared to pastures and increased with more intensive management (Fig. 3 A). In contrast, the average provision of other ES ( $C$ sequestration, plant species richness and in a lesser extend bee species richness) generally decreased with more intensive grassland land uses.

\footnotetext{
${ }^{5}$ For the three management intensity levels "intensive", "mid-intensive" (which we did not consider here) and "less intensive", 570 measurements were used from 120 sites (repetitions across years and/or botanical compositions within the sites). The equation were calculated using the mean yield measured on each site in order not to give more weight on the sites with more measurements. The overall $\mathrm{R}^{2}$ was 0.827 . For the management intensity level "extensive", we used the yield estimation from (Dietl, 1986).
} 
Despite spatial variability in $\mathrm{C}$ sequestration within grassland categories due to environmental factors, we observed a significant difference between intensive meadows versus all the other grasslands categories. Modelled C sequestration was on average positive in extensive pastures and in lessintensive and extensive meadows, implying that most of these grasslands categories were $\mathrm{C}$ sinks. In contrast, intensive grasslands were more likely to be $\mathrm{C}_{\text {sources }}{ }^{6}$ (Fig. $3 \mathrm{~B}$ ). Modelled bee species richness was also higher in extensive compared to intensive grassland regimes (Fig. $3 \mathrm{C}$ ). There was, however, no difference between less intensive and extensive meadows. Modelled plant species richness also decreased with more intensive management and took on average slightly higher values in meadows than in pastures (Fig. $3 \mathrm{D}$ ). For number of photos, ES values were higher for extensive than for more intensive grassland, especially in pastures (Fig. 3 E). For meadows, we find no differences. However, the spatial variability between parcels under the same grassland category was much higher in meadows compared to pastures. Information revealed by the frequency distributions was critical to determine what level of ES provision to expect from a specific management. For instance, bee species richness is likely to range between six and nine for lowland pastures under extensive management, whereas it is likely to range between four and six under intensive management.

\footnotetext{
${ }^{6}$ Negative value for intensively managed grasslands come from high exports which is a consequence of our assumption on $\mathrm{C}$ content of the biomass and on our data on yield
} 

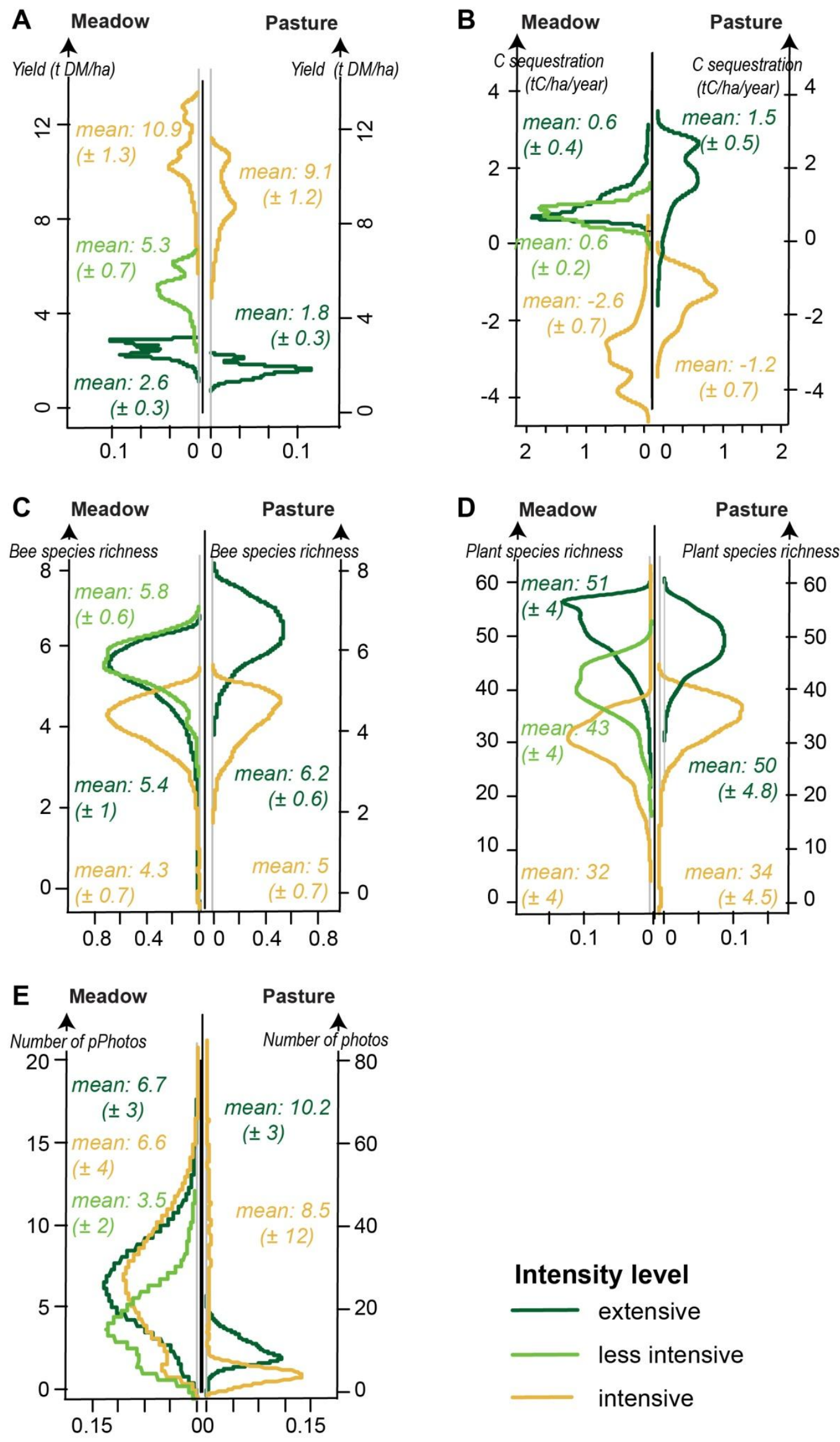

\section{Intensity level}

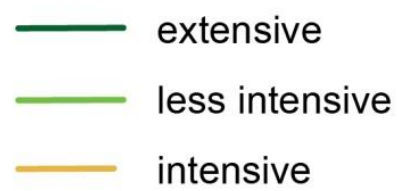


Figure 3. Density functions demonstrate the probability of the modelled ES provision under a specific management (i.e. regime and intensity). Means and standard deviations (in brackets) are given. A. Grassland yields; B. C sequestration. Positive values reveal $C$ sinks whereas negative values indicate $C$ sources; $C$. Bee species richness; $D$. Plant species richness and $E$. Number of photos. Density functions that demonstrate the probability of the measured ES provision under a specific management are presented in the Appendix 4.

\subsection{Revealing bundles, trade-offs and synergies within and across grassland categories}

Figure 4 reveals the relation between ES provision and its spatial variability between parcels under the same grassland category due to the underlying environmental factors. Across all intensity levels, higher provisions were related to higher spatial variability for yield as well as plant species richnessin meadows. However, this pattern was not revealed for bee species richness nor for the number of photos, especially for the bee species richness for which more intensive meadows led to lower and more variable provision. Multiple ES provision varied strongly from one grassland category to another (Fig. 4).

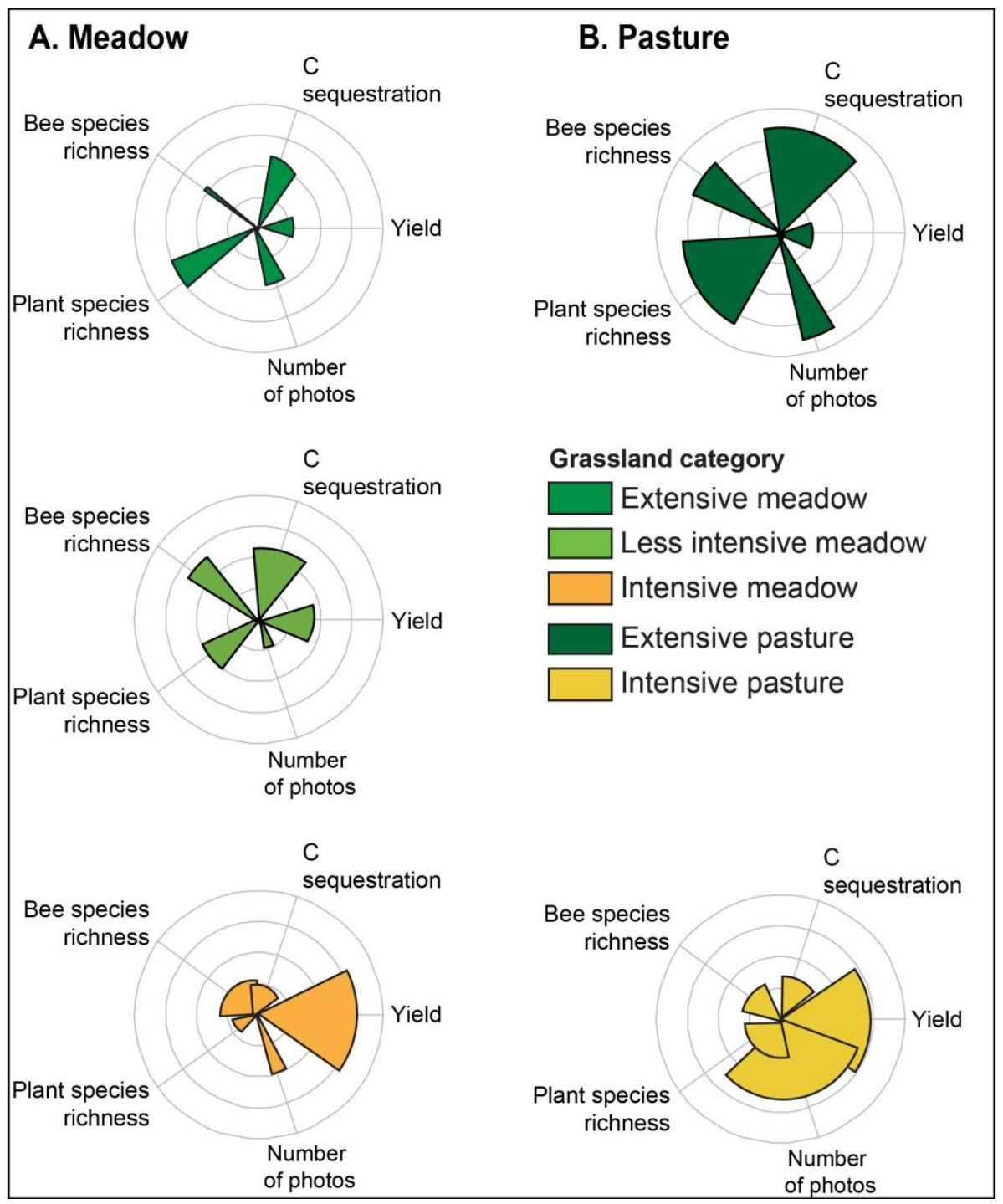

Figure 4. Bundles of the three intensity levels in terms of ES provision, A. for meadows and B. for pastures in the canton of Solothurn. The radius (length) of the wedges is proportional to the ES provision $\bar{E} \bar{S}$ and the angle (width) is proportional to the standard deviation $\bar{s} \bar{d}$. Wedges (length and width) were normalized through the PCA procedure.

Each grassland category exhibited a specific bundle of ES provision (length of the wedges). On average, intensive meadows were characterized by high yields and low plant species richness, bee species 
richness and $C$ sequestration. Less intensive meadows presented medium ES provision for all indicators but for the number of photos, which was low. Extensive meadows were characterized by high plant species richness, a medium provision of $C$ sequestration, bee species richness and number of photos but low yields. Similar trends could be observed for the ES provision in pastures. Intensive pastures were characterized by high yield, a high number of photos and low provision of the other ES indicators: plant species richness and bee species richness and $C$ sequestration, whereas extensive pastures were characterized by low yield and high plant species richness, bee species richness and $C$ sequestration.

The variability of the ES provision (width of the wedges) also depended on the ES and on the grassland category. In meadows, the overall variability of ES provision tends to decrease when going from intensive to extensive meadows. In intensive meadows, yield and bee species richness were very variable, whereas and the number of photos and plant species richness had little variability. Yield, $C$ sequestration, plant species richness and to a lesser extent, bee species richness, were relatively variable among less intensive meadows. The provision of all ES was expected to be quite homogeneous among extensive meadows. Yield, number of photos and plant species richness, and in a lesser extent, $C$ sequestration and bee species richness were very variable among intensive grasslands. Plant species richness and $C$ sequestration were very variable in extensive pastures, whereas the provision of the other ES was not likely to change greatly among grasslands under this management.

PCA analyses performed for each grassland category revealed antagonistic and synergistic relationships between the five individual ES indicators, emerging from the underlying environmental factors Fig. 6). They showed a very clear positive association between yield and plant species richness meaning that for a specific management regime and intensity, a parcel with high yields was likely to present relative higher plant species richness as well. The projection of the elevation on the correlations circle underlined the role of this environmental factor. Yield and plant species richness were likely to decrease in elevation. These two indicators were negatively correlated to the $\mathrm{C}$ sequestration, I nall grasslands but less intensive meadows. Bee species richness was correlated with the axis 2 of the PCA and most of the time uncorrelated to the other indicators. The correlation of the number of photos with the other indicators varied from one grassland category to another. In extensive meadow, it was positively correlated with the bee species richness. In intensive pastures, it was positively correlated with $\mathrm{C}$ sequestration and negatively correlated with the yield and plant species richness. In the other categories, it was not well correlated with the two first axes of the PCAs. 
MEADOW

Extensive

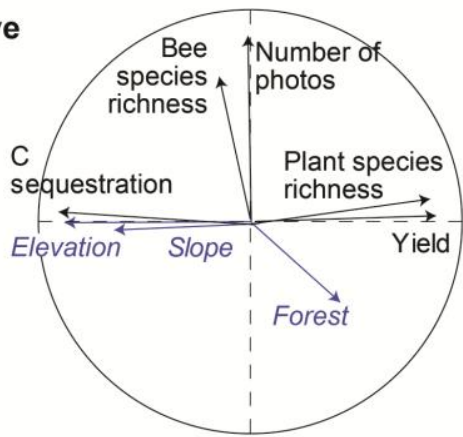

Less

Intensive

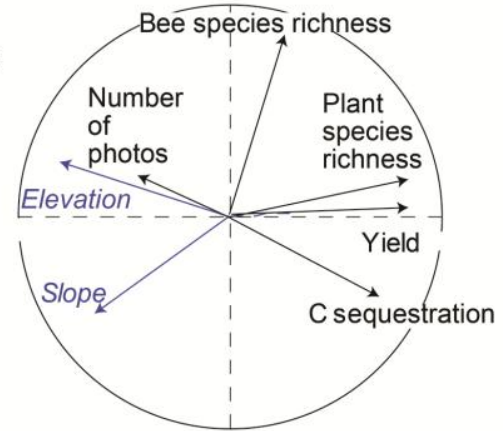

Intensive

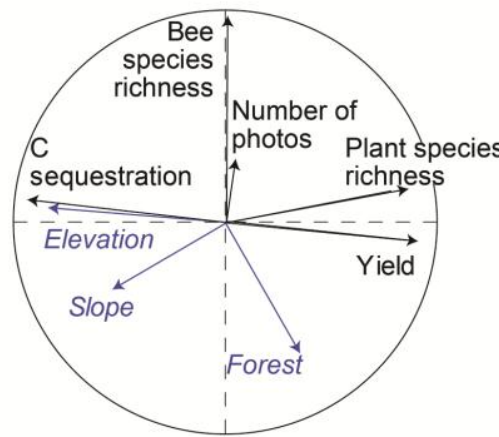

PASTURE
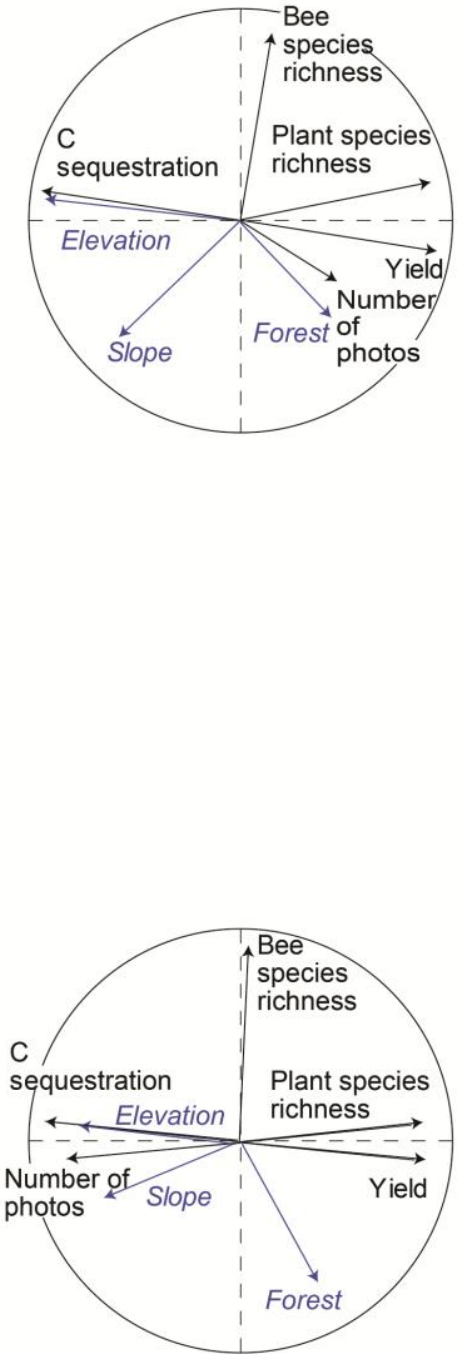

Figure 6. PCA performed on the five ES indicators, for the five grasslands categories. Correlation of each ES indicator with the two first factorial axes is shown (arrows point in the direction of highest values of the ES). The first factorial map (axes1 and 2) of the PCA explains between $60 \%$ and $86 \%$ of total inertia (or of total variance of dataset, $74 \%, 60 \%$ and $74 \%$ for the extensive, less intensive and intensive meadows, respectively and $80 \%$ and $86 \%$ for extensive and intensive pastures, respectively), depending of the grassland category. In blue and italic font, the environmental factors, projected as supplementary variables.

The antagonistic and synergistic relationships between the five individual ES indicators, based on our PCA analysis, showed very clear trade-offs at the cantonal level (Fig. 5): yield vs. C sequestration, bee species richness as well as plant species richness (Fig. $5 \mathrm{~A}$; axis 1). Number of photos could not be related as clearly to the other ES (axis 2). In terms of multiple ES provision, there was no clear distinction between the two regimes, at equal intensity level (Fig. 5 B). A clear shift exists between extensive versus intensive grasslands, irrespective of the regime. Even if there was a gradient from the extensive to the intensive grasslands, the proximity of the center of the scatter plots for extensive and less intensive meadows illustrated that the difference between these two intensity levels was tight, in the case of the selected ES indicators in our study region. The s-class analysis also highlights the considerable spatial variability in the interrelations between our ES indicators, as it was reflected in the dispersal of the dots (parcels). 


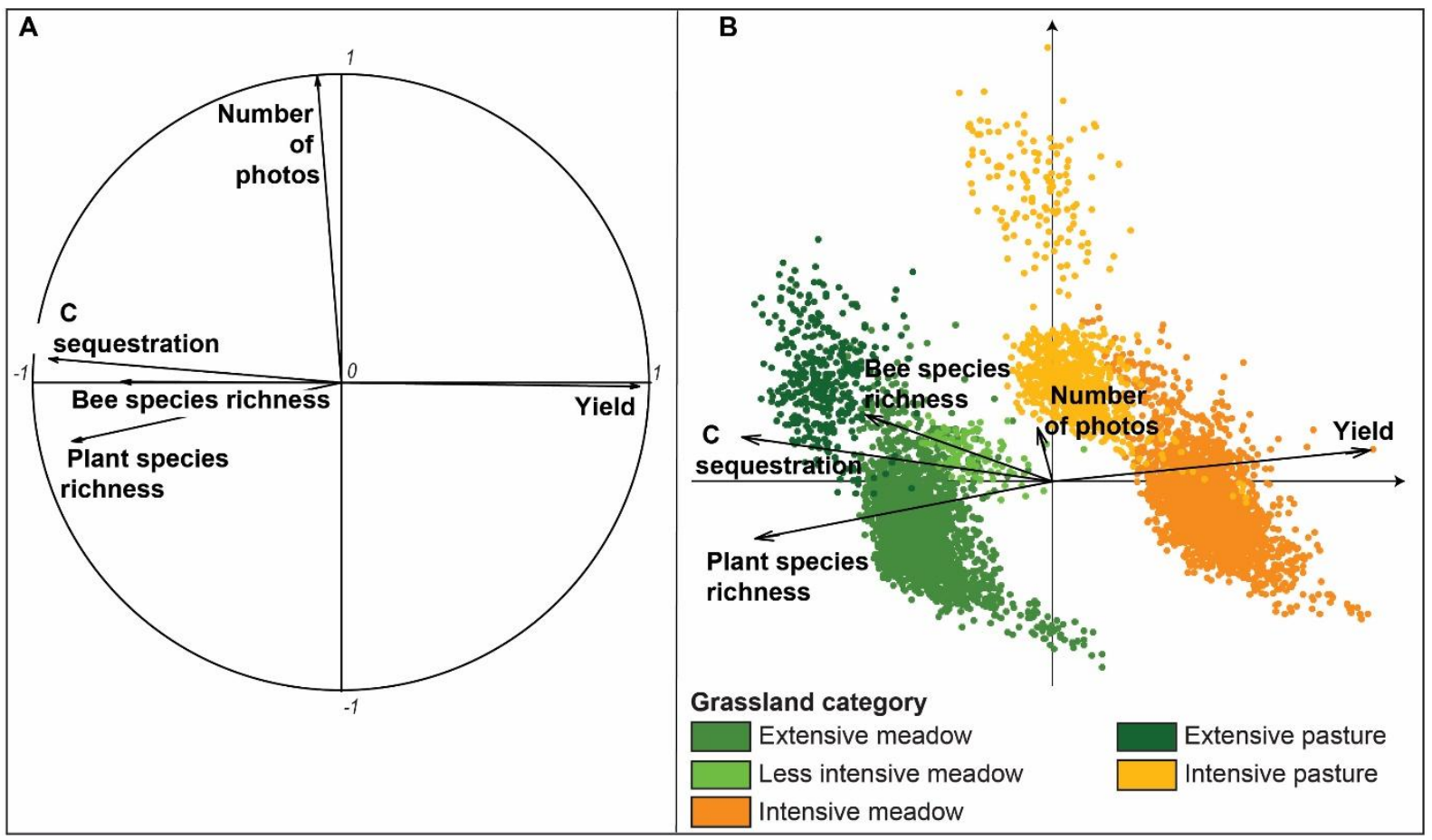

Figure 5. Principal Components Analysis (PCA) and constraint PCA performed on the five ES indicators and the grasslands categories. A. Correlation of each ES indicator with the two first factorial axes is shown (arrows point in the direction of highest values of the ES). The first factorial map (axes1 and 2) of the PCA explains approximately 82\% of total inertia (or of total variance of dataset). B. Factorial map associated to the correlation circle of the constraint PCA. Dots correspond to the parcels and are grouped by grassland category and their dispersal reflects the variability within the grassland categories; $R=$ $0.61, p$-value $<0,001)$. Pairwise correlations can be found in Appendix 5, table A7.

\subsection{Mapping multiple ES}

Grasslands in the Canton of Solothurn exhibited hotspot areas of ES across all elevations (Fig. 7 A). Four trends could be observed in the provision of multiple ES in our study area. The overall ES provision (overall score based on the five individual ES scores) was, on average, higher in pastures than in meadows (Fig. 7 C). This overall score increased with less intensive land uses (Fig. $7 \mathrm{C}$ and see Appendix 5). However, this result might be driven by the selection of our ES, as we modelled only one indicator of provisioning ES. The overall high ES provision was associated with high variation between parcels under the same grassland category (Fig. 7 B and 7 C). Independently from the modelled level of overall ES provision, some parcels could be considered as hotspots because their modelled overall ES provision was higher than the average overall ES provision under current land-use in the study region (Fig. 7 B). Finally, the overall scores in extensive and less intensively used grasslands were mainly driven by regulating and cultural ES, whereas the score was mainly driven by provisioning ES in intensive meadows and pastures (Fig. 7 D). The overall ES score was almost equally driven by the yield, bee, plant species richness and number of photos, which each contributed on average around $20 \%$ of the score, though C sequestration contributed to ca. $17 \%$. Decomposing the overall ES score is helpful to identify the potential of management options to provide multiple ES ant to target and tailor specific politic measures. 


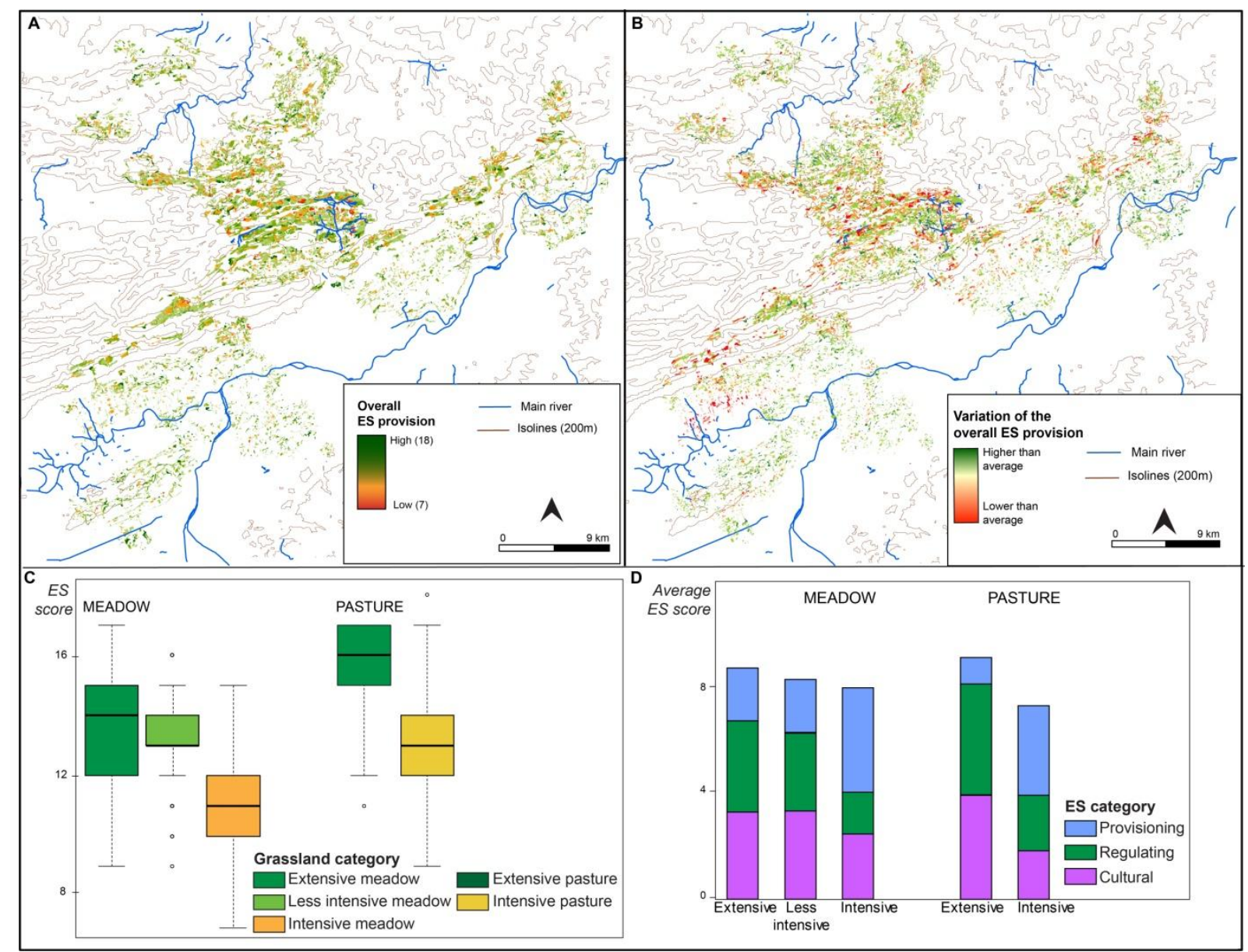

Figure 7. Overall ES provision in Canton of Solothurn. A. Spatial distribution of ES hotspots in Canton of Solothurn. B. Difference $\Delta$ between the modelled overall ES provision of the parcel and the average value of the corresponding grassland category. Negative variation means the modelled overall ES provision of a parcel is lower than the average for the grassland category. C. Variation of the overall ES score within and between the grassland categories, and D. Composition of the overall ES score in terms of different ES categories. The provisioning, regulating and cultural categories are constituted of one, two and two ES indicators, respectively. 


\section{Discussion and Conclusion}

In this study, we assessed the provision of five ES indicators and their variation between parcels under the same management practices in a multifunctional agricultural landscape. We also analyzed trade-offs and bundles induced by different management regimes and intensities. Our results highlight that the consideration of grassland categories, i.e., regime and intensity, is critical when assessing multiple ES and that information about land use only is not sufficient to model ES provision (Van der Biest et al., 2015).

We relied on a rich multi-source dataset. This dataset comprises census data as well as data on ES provision based on remote sensing- and field measurement. Census data gives information about the real landscape and management practices at the parcel level. This means that our results are given for the spatial distribution of permanent grasslands in Solothurn in 2017. Due to change in management, ES provision is likely to change over time. The use of field measurements allows us to identify drivers of the ES provision, account for the characteristics of the region and to validate our maps, through statistical approaches. Our multi-source dataset allowed us to integrate diverse ES indicators, related to different ecosystems and ecological functions and components.

\subsection{Associations and trade-offs in grassland ES}

Understanding of relationships among ES is key to support a sustainable management (Zhao et al., 2018), especially in multifunctional agricultural landscapes (Frei et al., 2018; Manning et al., 2018; Raudsepp-Hearne et al., 2010). In this contribution, we showed that associations in grassland ES strongly vary among grassland categories leading to trade-offs in ES provision on a landscape scale. This finding is in line with other studies addressing the impact of grassland management on multiple ES provision (e.g. Briner et al., 2013; Divinsky et al., 2017; Kim et al., 2016; Schirpke et al., 2017; Wu et al., 2017). Our results are also coherent in terms of order of magnitude and trends across the management and environmental factors with other studies in Swiss agroecosystems addressing plant and bee species richness, $C$ sequestration as well as for outdoor recreation (Dietschi et al., 2007; Junge et al., 2015; Kampmann et al., 2008; Le Feon et al., 2010). In addition to these studies, our results exemplify the spatial variability within different management strategies. We found that under the same management, flatter areas at low elevation tended to provide both relatively high yield and plant species compared to steeper areas on higher elevation (Wang et al., 2007).

Our results also reveal the spatial trade-offs between the provisioning service (forage production) and most of the other grassland ES as shown in other studies addressing grassland intensities (e.g. Allan et al., 2015; Simons and Weisser, 2017). These trade-offs between the provisioning and other services could be challenged by large-scale political strategies that would favor land sparing approaches (Qi et al., 2018). However, our results imply that there are exemptions depending on grassland categories and underlying environmental factors. In our case study, for example, yield and recreational services have positive associations in intensive but not in extensive meadows. Pollination services are highest in less intensive grasslands. This supports the finding that local associations might not scale up to the landscape level (Qiu et al., 2018) and that trade-offs can vary when considering multiple management options (Beckmann et al., 2019; Van Vooren et al., 2018). Therefore, while nearly all ES studies to date do not focus on the parcel level, our results strengthen the importance of considering different management regimes and intensities at the plot level as the key level for managing trade-offs and synergies in grassland ES. 


\subsection{Spatial variability in ES provision}

We also found that a higher overall provision increases the spatial variability of grassland ES. This does not only apply for provisioning services such as yield (e.g. Finger and Buchmann, 2015) but also for regulating and cultural ES. For plant species richness, climate regulation and bee species richness, a higher provision is also associated with higher variability in our case study region. We could not find existing literature that focused on the increase of variability with increasing levels of ES provision in grassland using empirical data.

Our results also highlight that while management practices are important drivers of ES provision and variability, they are not the only ones. As other studies previously showed, ES provision and their interrelations also vary according to biophysical and landscape components (Simons and Weisser, 2017). We found high spatial variability in regulating ES independent of grassland categories. In our study, some ES indicators, such as plant and bee species richness, are more influenced by landscape structure than by management practices. This is also true for the assessment of multiple ES, as existing research suggests that there is considerable influence of spatial levels and dynamics over time on the assessment of trade-offs and synergies among ES (Qiu et al., 2018; Rau et al., 2018; Sun and Li, 2017). Our results exemplify that spatial characteristics in combination with different management regimes amplifies the variabilities in the provision of multiple ES. This implies that the method to extrapolate different data sources into a multifunctional landscape is challenging. Future research should also test different types of how to model and map variabilities in ES provision (Andrew et al., 2015; Lavorel et al., 2017; Yang et al., 2018).

\subsection{Limitations}

Our results underline that the consideration of grassland categories on plot level is critical when assessing trade-offs in ES. Data availability is a crucial limitation in this respect. For some grasslands categories, we could only find a small number of observations, e.g. regarding the bee and plant species richness in pastures. Consequently, variabilities must be interpreted with care. In addition, we could not find sufficient information on the temporal variability in ES provision. This highlights important data gaps in ES trade-off assessments (Wong et al., 2015). Our study underlines the need for systematic information about the temporal variations in ES assessments to allow future research to capture ES relationships across space and time.

Because the environmental factors might affect differently the ES indicator, the variability of ES provision within and across grassland categories critically depends on the assessed ES indicator. Identifying ES indicators is challenging, especially because such choices can affect the trade-offs revealed between the indicators (Maes et al., 2016). We carefully chose indicators based on scientific literature, data availability and expert knowledge. Our chosen indicators have two major strengths. Firstly, they are diverse in terms of ES categories, underlying ecosystem functions and potential beneficiaries. Secondly, despite the effort to sample the data, they allow a certain replicability of the method to other agricultural landscapes. However, our assessment comprises one indicator of provisioning service, whereas it comprises two of regulating and two of cultural services. This asymmetry influences our results when identifying hotspot areas with an overall ES score. We chose to proceed with this asymmetrical design because of the lack of available data on forage quality. Considering the forage quality would have led to an assumption about the correlation between fertilizer and protein content. Because sward composition can be diverse under the same fertilization regime, such an assumption could generate high additional uncertainty.

\subsection{Policy and management implications}

The results from our analysis have two implications for policies addressing grassland management in European agriculture. Firstly, the spatial variability from underlying environmental factors would 
allow optimizing the spatial configuration of grassland management practices within a multifunctional landscape (Manning et al., 2018; Polasky et al., 2008; Simons and Weisser, 2017). The observation that forage production and biodiversity are positively associated within grassland categories, or management strategies, reinforces this potential since shifting grassland management in space could increase both ES simultaneously.

The extent of the gains from re-allocation of grassland categories, however, is constraint by agricultural structures i.e., the prevailing small-scaled and family based farming systems in Europe. Our results thus clearly underpin the importance of cross-scale interactions in grassland ES management (Qiu et al., 2018). While there is increased interest in such landscape level approaches (Meyer et al. 2017), the successful implementation of such collective policies is challenging (Prager, 2015).

Secondly, the varying trade-offs resulting from different grassland regimes and intensities that we observe in our case study region implies that the support of low intensive grassland for biodiversity does not automatically improve the provision of other services (Allan et al., 2015; Frei et al., 2018). This had been shown also in other recent assessments of multiple ES (Birkhofer et al., 2018; Frei et al., 2018) and makes it difficult to design agri-environmental schemes in grasslands that address multiple environmental objectives (Galler et al., 2015; Schader et al., 2014). In this context, result oriented agri-environmental measures could provide more effective and cost-efficient incentives to provide grassland ES (Engel, 2016; Meyer et al., 2015). However, spatial targeting and payment differentiation are only partially applied in practice (Wunder et al., 2018) and many agri-environmental measures are still action-oriented measures, i.e. paying farmers for the delivery of input-reducing land management practices rather than the effective results (Burton and Schwarz, 2013). Thus, knowledge and information about spatial variability and the trade-offs from different grassland management practices as presented in our study will be of high importance for the design of effective and efficient agri-environmental policies in European agriculture.

\section{Acknowledgements}

This work is supported by an ETH research grant for the project VALUEGRASS. Nina Buchmann acknowledges support from various projects over the last years from the SNF and the EU enabling flux measurements over grasslands.

\section{References}

Allan, E., Manning, P., Alt, F., Binkenstein, J., Blaser, S., Blüthgen, N., Böhm, S., Grassein, F., Hölzel, N., Klaus Valentin, H., Kleinebecker, T., Morris, E.K., Oelmann, Y., Prati, D., Renner Swen, C., Rillig Matthias, C., Schaefer, M., Schloter, M., Schmitt, B., Schöning, I., Schrumpf, M., Solly, E., Sorkau, E., Steckel, J., Steffen-Dewenter, I., Stempfhuber, B., Tschapka, M., Weiner Christiane, N., Weisser Wolfgang, W., Werner, M., Westphal, C., Wilcke, W., Fischer, M., Knops, J., 2015. Land use intensification alters ecosystem multifunctionality via loss of biodiversity and changes to functional composition. Ecology Letters 18, 834-843.

Andrew, M.E., Wulder, M.A., Nelson, T.A., Coops, N.C., 2015. Spatial data, analysis approaches, and information needs for spatial ecosystem service assessments: a review. GIScience \& Remote Sensing 52, 344-373.

Authier, M., Saraux, C., Péron, C., 2017. Variable selection and accurate predictions in habitat modelling: a shrinkage approach. Ecography 40, 549-560.

Baldocchi, D., Chu, H., Reichstein, M., 2017. Inter-annual variability of net and gross ecosystem carbon fluxes: A review. Agricultural and Forest Meteorology. 
Beckmann, M., Gerstner, K., Akin-Fajiye, M., Ceausu, S., Kambach, S., Kinlock, N.L., Phillips, H.R.P., Verhagen, W., Gurevitch, J., Klotz, S., Newbold, T., Verburg, P.H., Winter, M., Seppelt, R., 2019. Conventional land-use intensification reduces species richness and increases production: A global meta-analysis. Global Change Biology 25, 1941-1956.

Bengtsson, J., Bullock, J.M., Egoh, B., Everson, C., Everson, T., O'Connor, T., O'Farrell, P.J., Smith, H.G., Lindborg, R., 2019. Grasslands-more important for ecosystem services than you might think.

Ecosphere 10, e02582.

Bennett, E.M., Peterson, G.D., Gordon, L.J., 2009. Understanding relationships among multiple ecosystem services. Ecology Letters 12, 1394-1404.

Birkhofer, K., Andersson, G.K.S., Bengtsson, J., Bommarco, R., Dänhardt, J., Ekbom, B., Ekroos, J., Hahn, T., Hedlund, K., Jönsson, A.M., Lindborg, R., Olsson, O., Rader, R., Rusch, A., Stjernman, M., Williams, A., Smith, H.G., 2018. Relationships between multiple biodiversity components and ecosystem services along a landscape complexity gradient. Biological Conservation 218, 247-253. Blair, J., Nippert, J., Briggs, J., 2014. Grassland Ecology, in: Monson, R.K. (Ed.), Ecology and the Environment. Springer, pp. 389-423.

Briner, S., Elkin, C., Huber, R., 2013. Evaluating the relative impact of climate and economic changes on forest and agricultural ecosystem services in mountain regions. Journal of Environmental Management 129, 414-422.

Bruun, H.H., 2001. Determinants of species richness in patches of grassland and heathland in Himmerland (Denmark). Nordic Journal of Botany 21, 607-614.

Burton, R.J.F., Schwarz, G., 2013. Result-oriented agri-environmental schemes in Europe and their potential for promoting behavioural change. Land Use Policy 30, 628-641.

Chang, J., Ciais, P., Viovy, N., Vuichard, N., Sultan, B., Soussana, J.-F., 2015. The greenhouse gas balance of European grasslands. Global Change Biology 21, 3748-3761.

Colson, V., Garcia, S., Rondeux, J., Lejeune, P., 2010. Map and determinants of woodlands visiting in Wallonia. Urban Forestry \& Urban Greening 9, 83-91.

Dauber, J., Hirsch, M., Simmering, D., Waldhardt, R., Otte, A., Wolters, V., 2003. Landscape structure as an indicator of biodiversity: Matrix effects on species richness.

Dietl, W., 1986. Pflanzenbestand, Bewirtschaftungsintensität und Ertragspotential von Dauerwiesen. Dietschi, S., Holderegger, R., Schmidt, S.G., Linder, P., 2007. Agri-environment incentive payments and plant species richness under different management intensities in mountain meadows of Switzerland. Acta Oecologica 31, 216-222.

Divinsky, I., Becker, N., Bar, P., 2017. Ecosystem service tradeoff between grazing intensity and other services - A case study in Karei-Deshe experimental cattle range in northern Israel. Ecosystem Services 24, 16-27.

Duflot, R., Ernoult, A., Aviron, S., Fahrig, L., Burel, F., 2017. Relative effects of landscape composition and configuration on multi-habitat gamma diversity in agricultural landscapes. Agriculture, Ecosystems \& Environment 241, 62-69.

Edwards, D., Jay, M., Jensen, F.S., Lucas, B., Marzano, M., Montagne, C., Peace, A., Weiss, G., 2012. Public preferences for structural attributes of forests: Towards a pan-European perspective. Forest Policy and Economics 19, 12-19.

Engel, S., 2016. The devil in the detail: a practical guide on designing payments for environmental services. International Review of Environmental and Resource Economics 9, 131-177.

Feng, Q., Zhao, W., Fu, B., Ding, J., Wang, S., 2017. Ecosystem service trade-offs and their influencing factors: A case study in the Loess Plateau of China. Science of The Total Environment 607-608, 12501263.

Finger, R., Buchmann, N., 2015. An ecological economic assessment of risk-reducing effects of species diversity in managed grasslands. Ecological Economics 110, 89-97.

FOAG, 2005. Cartes des aptitudes des sols de la Suisse.

Frei, B., Renard, D., Mitchell Matthew, G.E., Seufert, V., Chaplin-Kramer, R., Rhemtulla, J.M., Bennett, E.M., 2018. Bright spots in agricultural landscapes: Identifying areas exceeding expectations for multifunctionality and biodiversity. Journal of Applied Ecology 0. 
FSO, 2015. Federal Statistical Office.

Galler, C., von Haaren, C., Albert, C., 2015. Optimizing environmental measures for landscape multifunctionality: Effectiveness, efficiency and recommendations for agri-environmental programs. Journal of Environmental Management 151, 243-257.

GELAN, 2018. Agrarinformationssystem GELAN. Office de l'agriculture et de la nature.

Gul, A., Orucu, M.K., Karaca, O., 2006. An approach for recreation suitability analysis to recreation planning in Golcuk Nature Park. Environmental Management 37, 606-625.

Habel, J.C., Dengler, J., Janišová, M., Török, P., Wellstein, C., Wiezik, M., 2013. European grassland ecosystems: threatened hotspots of biodiversity. Biodiversity and Conservation 22, 2131-2138.

Harrison, P.A., Vandewalle, M., Sykes, M.T., Berry, P.M., Bugter, R., de Bello, F., Feld, C.K., Grandin, U., Harrington, R., Haslett, J.R., Jongman, R.H.G., Luck, G.W., da Silva, P.M., Moora, M., Settele, J., Sousa, J.P., Zobel, M., 2010. Identifying and prioritising services in European terrestrial and freshwater ecosystems. Biodiversity and Conservation 19, 2791-2821.

Hendrickx, F., Maelfait, J.-P., Van Wingerden, W., Schweiger, O., Speelmans, M., Aviron, S., Augenstein, I., Billeter, R., Bailey, D., Bukacek, R., Burel, F., DiekÖTter, T.I.M., Dirksen, J., Herzog, F., Liira, J., Roubalova, M., Vandomme, V., Bugter, R.O.B., 2007. How landscape structure, land-use intensity and habitat diversity affect components of total arthropod diversity in agricultural landscapes. Journal of Applied Ecology 44, 340-351.

Herzog, F., Dreier, S., Hofer, G., Marfurt, C., Schüpbach, B., Spiess, M., Walter, T., 2005. Effect of ecological compensation areas on floristic and breeding bird diversity in Swiss agricultural landscapes. Agriculture, Ecosystems \& Environment 108, 189-204.

Hoeting, J.A., Davis, R.A., Merton, A.A., Thompson, S.E., 2006. Model Selection For Geostatistical Models. Ecological Applications 16, 87-98.

Huber, R., Snell, R., Monin, F., Brunner, S.H., Schmatz, D., Finger, R., 2017. Interaction effects of targeted agri-environmental payments on non-marketed goods and services under climate change in a mountain region. Land Use Policy 66, 49-60.

Hudewenz, A., Klein, A.-M., Scherber, C., Stanke, L., Tscharntke, T., Vogel, A., Weigelt, A., Weisser, W.W., Ebeling, A., 2012. Herbivore and pollinator responses to grassland management intensity along experimental changes in plant species richness. Biological Conservation 150, 42-52.

Huguenin-Elie, O., Mosimann, E., Schlegel, P., Lüscher, A., Kessler, W., Jeangros, B., 2017. Fertilisation des herbages. Recherche agronomique Suisse 8, 143-165.

IPCC, 2006. Agriculture, Forestry and Other Land Use, in: Eggleston, H.S., Buendia, L., Miwa, K., Ngara, T., Tanabe, K. (Eds.), Guidelines for National Greenhouse Gas Inventories. IGES, Japan. Jarvis, A., Reuter, H.I., Nelso, A., Guevara, E., 2008. Hole-filled SRTM for the globe version 4, in: SRTM, C.-C. (Ed.).

Jeanneret, P., Huguenin-Elie, O., Baumgartner, D., Freiermuth Knuchel, R., Gaillard, G., Nemecek, T., Weibel, P., 2007. Analysis of spatial and temporal variations of High Nature Value farmland and links with changes in bird populations: a study on France. Grassland Science in Europe 12, 382-385.

Junge, X., Schüpbach, B., Walter, T., Schmid, B., Lindemann-Matthies, P., 2015. Aesthetic quality of agricultural landscape elements in different seasonal stages in Switzerland. Landscape and Urban Planning 133, 67-77.

Kampmann, D., Herzog, F., Jeanneret, P., Konold, W., Peter, M., Walter, T., Wildi, O., Lüscher, A., 2008. Mountain grassland biodiversity: Impact of site conditions versus management type. Journal for Nature Conservation 16, 12-25.

Kampmann, D., Lüscher, A., Konold, W., Herzog, F., 2012. Agri-environment scheme protects diversity of mountain grassland species. Land Use Policy 29, 569-576.

Kim, J.H., Jobbágy, E.G., Jackson, R.B., 2016. Trade-offs in water and carbon ecosystem services with land-use changes in grasslands. Ecological Applications 26, 1633-1644.

Kramer, D., Hartter, J., Boag, A., Jain, M., Stevens, K., Nicholas, K., McConnell, W., Liu, J., 2017. Top 40 questions in coupled human and natural systems (CHANS) research. Ecology and Society 22. 
Lavorel, S., Bayer, A., Bondeau, A., Lautenbach, S., Ruiz-Frau, A., Schulp, N., Seppelt, R., Verburg, P., Teeffelen, A.v., Vannier, C., Arneth, A., Cramer, W., Marba, N., 2017. Pathways to bridge the biophysical realism gap in ecosystem services mapping approaches. Ecological Indicators 74, 241-260. Lavorel, S., Grigulis, K., Lamarque, P., Colace, M.P., Garden, D., Girel, J., Pellet, G., Douzet, R., 2011. Using plant functional traits to understand the landscape distribution of multiple ecosystem services. Journal of Ecology 99, 135-147.

Le Clec'h, S., Oszwald, J., Decaens, T., Desjardins, T., Dufour, S., Grimaldi, M., Jegou, N., Lavelle, P., 2016. Mapping multiple ecosystem services indicators: Toward an objective-oriented approach. Ecological Indicators 69, 508-521.

Le Feon, V., Schermann-Legionnet, A., Delettre, Y., Aviron, S., Billeter, R., Bugter, R., Hendrickx, F., Burel, F., 2010. Intensification of agriculture, landscape composition and wild bee communities: A large scale study in four European countries. Agriculture Ecosystems \& Environment 137, 143-150. Lindemann-Matthies, P., Briegel, R., Schüpbach, B., Junge, X., 2010. Aesthetic preference for a Swiss alpine landscape: The impact of different agricultural land-use with different biodiversity. Landscape and Urban Planning 98, 99-109.

Lüscher, G., Ammari, Y., Andriets, A., Angelova, S., Arndorfer, M., Bailey, D., Balázs, K., Bogers, M., Bunce, R.G.H., Choisis, J.-P., Dennis, P., Díaz, M., Dyman, T., Eiter, S., Fjellstad, W., Fraser, M., Friedel, J.K., Garchi, S., Geijzendorffer, I.R., Gomiero, T., González-Bornay, G., Guteva, Y., Herzog, F., Jeanneret, P., Jongman, R.H.G., Kainz, M., Kwikiriza, N., López Díaz, M.L., Moreno, G., NicholasDavies, P., Nkwiine, C., Opio, J., Paoletti, M.G., Podmaniczky, L., Pointereau, P., Pulido, F., Sarthou, J.P., Schneider, M.K., Sghaier, T., Siebrecht, N., Stoyanova, S., Wolfrum, S., Yashchenko, S., Albrecht, H., Báldi, A., Belényesi, M., Benhadi-Marin, J., Blick, T., Buholzer, S., Centeri, C., Choisis, N., Cuendet, G., De Lange, H.J., Déjean, S., Deltshev, C., Díaz Cosín, D.J., Dramstad, W., Elek, Z., Engan, G., Evtushenko, K., Falusi, E., Finch, O.-D., Frank, T., Gavinelli, F., Genoud, D., Gillingham, P.K., Grónás, V., Gutiérrez, M., Häusler, W., Heer, X., Hübner, T., Isaia, M., Jerkovich, G., Jesus, J.B., Kakudidi, E., Kelemen, E., Koncz, N., Kovacs, E., Kovács-Hostyánszki, A., Last, L., Ljubomirov, T., Mandery, K., Mayr, J., Mjelde, A., Muster, C., Nascimbene, J., Neumayer, J., Ødegaard, F., Ortiz Sánchez, F.J., Oschatz, M.L., Papaja-Hülsbergen, S., Paschetta, M., Pavett, M., Pelosi, C., Penksza, K., Pommeresche, R., Popov, V., Radchenko, V., Richner, N., Riedel, S., Scullion, J., Sommaggio, D., Szalkovszki, O., Szerencsits, E., Trigo, D., Vale, J., van Kats, R., Vasilev, A., Whittington, A.E., Wilkes-Allemann, J., Zanetti, T., 2016. Farmland biodiversity and agricultural management on 237 farms in 13 European and two African regions. Ecology 97, 1625-1625.

Mace, G.M. , Norris, K., Fitter, A.H., 2012. Biodiversity and ecosystem services: a multilayered relationship, Trends in Ecology \& Evolution 27(1), 19-26.

Maes, J., Liquete, C., Teller, A., Erhard, M., Paracchini, M.L., Barredo, J.I., Grizzetti, B., Cardoso, A., Somma, F., Petersen, J.-E., Meiner, A., Gelabert, E.R., Zal, N., Kristensen, P., Bastrup-Birk, A., Biala, K., Piroddi, C., Egoh, B., Degeorges, P., Fiorina, C., Santos-Martín, F., Naruševičius, V., Verboven, J., Pereira, H.M., Bengtsson, J., Gocheva, K., Marta-Pedroso, C., Snäll, T., Estreguil, C., San-Miguel-Ayanz, J., Pérez-Soba, M., Grêt-Regamey, A., Lillebø, A.I., Malak, D.A., Condé, S., Moen, J., Czúcz, B., Drakou, E.G., Zulian, G., Lavalle, C., 2016. An indicator framework for assessing ecosystem services in support of the EU Biodiversity Strategy to 2020. Ecosystem Services 17, 14-23.

Maes, J., Paracchini, M.L., Zulian, G., Dunbar, M.B., Alkemade, R., 2012. Synergies and trade-offs between ecosystem service supply, biodiversity, and habitat conservation status in Europe. Biological Conservation 155, 1-12.

Mallow, C.L., 1973. Some Comments on CP. Technometrics 15, 661-675.

Manning, P., van der Plas, F., Soliveres, S., Allan, E., Maestre, F.T., Mace, G., Whittingham, M.J., Fischer, M., 2018. Redefining ecosystem multifunctionality. Nature Ecology \& Evolution 2, 427-436.

Marini, L., Fontana, P., Scotton, M., Klimek, S., 2008. Vascular plant and Orthoptera diversity in relation to grassland management and landscape composition in the European Alps. Journal of Applied Ecology 45, 361-370.

Matthews, A., 2013. Greening agricultural payments in the EU's Common Agricultural Policy. Biobased and Applied Economics 2, 1-27. 
Meyer, C., Reutter, M., Matzdorf, B., Sattler, C., Schomers, S., 2015. Design rules for successful governmental payments for ecosystem services: Taking agri-environmental measures in Germany as an example. Journal of Environmental Management 157, 146-159.

Meyer, S., Unternährer, D., Arlettaz, R., Humbert, J.-Y., Menz, M.H.M., 2017. Promoting diverse communities of wild bees and hoverflies requires a landscape approach to managing meadows. Agriculture, Ecosystems \& Environment 239, 376-384.

Mosimann, E., 2005. Caractéristiques des pâturages pour vaches laitières dans l'ouest de la Suisse. Revue suisse d'agriculture 37, 99-106.

Mouchet, M.A., Lamarque, P., Martín-López, B., Crouzat, E., Gos, P., Byczek, C., Lavorel, S., 2014. An interdisciplinary methodological guide for quantifying associations between ecosystem services. Global Environmental Change 28, 298-308.

Navarro, A., López-Bao, J.V., 2018. Towards a greener Common Agricultural Policy. Nature Ecology \& Evolution 2, 1830-1833.

Nogué, S., Long, P.R., Eycott, A.E., de Nascimento, L., Fernández-Palacios, J.M., Petrokofsky, G., Vandvik, V., Willis, K.J., 2016. Pollination service delivery for European crops: Challenges and opportunities. Ecological Economics 128, 1-7.

Pastorello, G.Z., Papale, D., Chu, H., Trotta, C., Agarwal, D.A., Canfora, E., Baldocchi, D.D., Torn, M.S., 2017. A new data set to keep a sharper eye on land-air exchanges. Eos 98.

Pe'er, G., Dicks, L.V., Visconti, P., Arlettaz, R., Báldi, A., Benton, T.G., Collins, S., Dieterich, M., Gregory, R.D., Hartig, F., Henle, K., Hobson, P.R., Kleijn, D., Neumann, R.K., Robijns, T., Schmidt, J., Shwartz, A., Sutherland, W.J., Turbé, A., Wulf, F., Scott, A.V., 2014. EU agricultural reform fails on biodiversity. Science 344, 1090-1092.

Petter, M., Mooney, S., Maynard, S.M., Davidson, A., Cox, M., Horosak, I., 2013. A Methodology to Map Ecosystem Functions to Support Ecosystem Services Assessments. Ecology and Society 18. Polasky, S., Nelson, E., Camm, J., Csuti, B., Fackler, P., Lonsdorf, E., Montgomery, C., White, D., Arthur, J., Garber-Yonts, B., Haight, R., Kagan, J., Starfield, A., Tobalske, C., 2008. Where to put things? Spatial land management to sustain biodiversity and economic returns. Biological Conservation 141, 1505-1524.

Prager, K., 2015. Agri-environmental collaboratives for landscape management in Europe. Current Opinion in Environmental Sustainability 12, 59-66.

Qi, A., Holland, R.A., Taylor, G., Richter, G.M., 2018. Grassland futures in Great Britain - Productivity assessment and scenarios for land use change opportunities. Science of The Total Environment 634, 1108-1118.

Qiu, J., Carpenter, S.R., Booth, E.G., Motew, M., Zipper, S.C., Kucharik, C.J., Loheide, I.S., P., Turner, M.G., 2018. Understanding relationships among ecosystem services across spatial scales and over time. Environmental Research Letters 13, 054020.

R Development Core Team, 2018. R: A language and environment for statistical computing. $R$ Foundation for Statistical Computing, Vienna, Austria.

Rau, A.-L., von Wehrden, H., Abson, D.J., 2018. Temporal Dynamics of Ecosystem Services. Ecological Economics 151, 122-130.

Raudsepp-Hearne, C., Peterson, G.D., 2016. Scale and ecosystem services: how do observation, management, and analysis shift with scale\&\#8212;lessons from Qu\&\#233;bec. Ecology and Society 21.

Raudsepp-Hearne, C., Peterson, G.D., Bennett, E.M., 2010. Ecosystem service bundles for analyzing tradeoffs in diverse landscapes. Proceedings of the National Academy of Sciences.

Reitalu, T., Sykes, M.T., Johansson, L.J., Lönn, M., Hall, K., Vandewalle, M., Prentice, H.C., 2009. Smallscale plant species richness and evenness in semi-natural grasslands respond differently to habitat fragmentation. Biological Conservation 142, 899-908.

Rodríguez, J.P., Beard, T.D.J., Bennett, E.M., Cumming, G.S., Cork, S., Agard, J., Dobson, A.P., Peterson, G.D., 2006. Trade-offs across space, time, and ecosystem services. Ecology and Society 11(1): 28. [online] URL: http://www.ecologyandsociety.org/vol11/iss1/art28/. 
Rogers, S.R., Tarpy, D.R., Burrack, H.J., 2014. Bee Species Diversity Enhances Productivity and Stability in a Perennial Crop. PLoS One 9, e97307.

Schader, C., Lampkin, N., Muller, A., Stolze, M., 2014. The role of multi-target policy instruments in agri-environmental policy mixes. Journal of Environmental Management 145, 180-190.

Schirpke, U., Kohler, M., Leitinger, G., Fontana, V., Tasser, E., Tappeiner, U., 2017. Future impacts of changing land-use and climate on ecosystem services of mountain grassland and their resilience.

Ecosystem Services 26, 79-94.

Schulp, C.J.E., Burkhard, B., Maes, J., Van Vliet, J., Verburg, P.H., 2014. Uncertainties in Ecosystem Service Maps: A Comparison on the European Scale. PLoS One 9, e109643.

Simons, N.K., Weisser, W.W., 2017. Agricultural intensification without biodiversity loss is possible in grassland landscapes. Nat Ecol Evol 1, 1136-1145.

Spake, R., Lasseur, R., Crouzat, E., Bullock, J.M., Lavorel, S., Parks, K.E., Schaafsma, M., Bennett, E.M., Maes, J., Mulligan, M., Mouchet, M., Peterson, G.D., Schulp, C.J.E., Thuiller, W., Turner, M.G., Verburg, P.H., Eigenbrod, F., 2017. Unpacking ecosystem service bundles: Towards predictive mapping of synergies and trade-offs between ecosystem services. Global Environmental Change 47, 37-50.

Sun, X., Li, F., 2017. Spatiotemporal assessment and trade-offs of multiple ecosystem services based on land use changes in Zengcheng, China. Science of The Total Environment 609, 1569-1581.

Tscharntke, T., Tylianakis, J.M., Rand, T.A., Didham, R.K., Fahrig, L., Batary, P., Bengtsson, J., Clough, Y., Crist, T.O., Dormann, C.F., Ewers, R.M., Frund, J., Holt, R.D., Holzschuh, A., Klein, A.M., Kleijn, D., Kremen, C., Landis, D.A., Laurance, W., Lindenmayer, D., Scherber, C., Sodhi, N., Steffan-Dewenter, I., Thies, C., van der Putten, W.H., Westphal, C., 2012. Landscape moderation of biodiversity patterns and processes - eight hypotheses. Biol Rev Camb Philos Soc 87, 661-685.

Uthes, S., Matzdorf, B., 2013. Studies on Agri-environmental Measures: A Survey of the Literature. Environmental Management 51, 251-266.

Vallet, A., Locatelli, B., Levrel, H., Wunder, S., Seppelt, R., Scholes, R.J., Oszwald, J., 2018.

Relationships between ecosystem services: Comparing methods for assessing tradeoffs and synergies. Ecological Economics 150, 96-106.

Van der Biest, K., Vrebos, D., Staes, J., Boerema, A., Bodí, M.B., Fransen, E., Meire, P., 2015. Evaluation of the accuracy of land-use based ecosystem service assessments for different thematic resolutions. Journal of Environmental Management 156, 41-51.

Van Vooren, L., Reubens, B., Broekx, S., Reheul, D., Verheyen, K., 2018. Assessing the impact of grassland management extensification in temperate areas on multiple ecosystem services and biodiversity. Agriculture, Ecosystems \& Environment 267, 201-212.

Vannier, C., Lasseur, R., Crouzat, E., Byczek, C., Lafond, V., Cordonnier, T., Longaretti, P.-Y., Lavorel, S., 2019. Mapping ecosystem services bundles in a heterogeneous mountain region. Ecosystems and People 15, 74-88.

Verhagen, W., van der Zanden, E.H., Strauch, M., van Teeffelen, A.J.A., Verburg, P.H., 2018.

Optimizing the allocation of agri-environment measures to navigate the trade-offs between ecosystem services, biodiversity and agricultural production. Environmental Science \& Policy 84, 186196.

Wang, C.T., Long, R.J., Wang, Q.J., Ding, L.M., Wang, M.P., 2007. Effects of altitude on plant-species diversity and productivity in an alpine meadow, QinghaiTibetan plateau. Australian Journal of Botany 55, 110-117.

Wong, C.P., Jiang, B., Kinzig, A.P., Lee, K.N., Ouyang, Z., 2015. Linking ecosystem characteristics to final ecosystem services for public policy. Ecology Letters 18, 108-118.

Wu, J., Zhao, Y., Yu, C., Luo, L., Pan, Y., 2017. Land management influences trade-offs and the total supply of ecosystem services in alpine grassland in Tibet, China. Journal of Environmental Management 193, 70-78.

Wunder, S., Brouwer, R., Engel, S., Ezzine-de-Blas, D., Muradian, R., Pascual, U., Pinto, R., 2018. From principles to practice in paying for nature's services. Nature Sustainability 1, 145-150. 
Yang, S., Zhao, W., Liu, Y., Wang, S., Wang, J., Zhai, R., 2018. Influence of land use change on the ecosystem service trade-offs in the ecological restoration area: Dynamics and scenarios in the Yanhe watershed, China. Science of The Total Environment 644, 556-566.

Zhao, W., Liu, Y., Daryanto, S., Fu, B., Wang, S., Liu, Y., 2018. Metacoupling supply and demand for soil conservation service. Current Opinion in Environmental Sustainability 33, 136-141.

\section{Appendix}

\section{Appendix 1: ES variables}

Yield

\begin{tabular}{|l|l|}
\hline Type of data & Parameters of linear regressions \\
\hline How data was acquired & Equations described in Huguenin-Elie et al. 2017 \\
\hline
\end{tabular}

Such equations are crucial to estimate yields in the Swiss context if there are no field data available. The equations reported in Huguenin-Elie et al. (2017)were used to calculate the average yield for the elevation concerned in Switzerland. For each management regime and intensity level, an equation links elevation to the yields. Below 500 m elevation, the yield does not vary significantly with elevation; the estimated yield is therefore equivalent to that calculated for an elevation at $500 \mathrm{~m}$. All equations are based on field work.

Net $\mathrm{CO}_{2}$ ecosystem exchange

\begin{tabular}{|l|l|}
\hline Type of data & Quality-controlled ecosystem $\mathrm{CO}_{2}$ fluxes \\
\hline How data was acquired & Field work \\
\hline Data format & Raw \\
\hline Experimental features & In-situ eddy covariance measurements at ecosystem scale globally \\
\hline Data source location & Site locations are given with their official identifier in brackets. \\
& Switzerland: Chamau (CH-Cha), Früebüel (CH-Fru), Oensingen (CH-Oe1); \\
& Denmark: Enghave (DK-Eng), Rimi (DK-Lva); France: Laqueuille extensive \\
& (FR-Lq2), Laqueuille intensive (FR-Lq1), Lusignan (FR-Lus); Germany: \\
& Grillenburg (DE-Gri), Mehrstedt 2 (DE-Me2), Rollesbroich (DE-RuR); Hungary: \\
& Bugac (HU-Bug), Matra (HU-Mat); Ireland: Dripsey (IE-Dri); Italy: Monte \\
& Bondone (IT-Mbo); The Netherlands: Cabauw (NL-Ca1); UK: Easter Bush (UK- \\
& EBu) \\
\hline Data accessibility & Public repositories, available at European Fluxes Database Cluster \\
& (http://gaia.agraria.unitus.it/home) and FLUXNET2015 dataset \\
& (http://fluxnet.fluxdata.org/data/fluxnet2015-dataset) \\
\hline
\end{tabular}

The Fluxnet database provides data on net ecosystem $\mathrm{CO}_{2}$ fluxes and further atmospheric variables in grasslands (among other ecosystem types) around the world. Measurements of $\mathrm{CO}_{2}$ fluxes can serve as inputs into models that predict the cycling of carbon, to detect the trends in climate, greenhouse gases and to understand how and why atmospheric state variables may vary across space.

Net ecosystem $\mathrm{CO}_{2}$ exchange was measured using flux tower stations in temperate grasslands across the world. Some data were available online, other were requested from the person responsible for the respective station.

We used daily values derived from half-hourly data for the Net Ecosystem Exchange of $\mathrm{CO}_{2}$ (USTAR Threshold; VUT) measured by eddy-covariance. An indicator of quality, ranging from 0 to 1 , is associated with the data. We excluded the data whose values were below a quality control value of 0.66 
and rejected the time series when it was not gapfilled. From the half-hourly data, we calculated the cumulative sum per year.

Bee and plant species richness

\begin{tabular}{|l|l|}
\hline Type of data & Biodiversity survey \\
\hline How data was acquired & Field work \\
\hline Data format & Raw \\
\hline Experimental features & $\begin{array}{l}\text { Data were collected at 19 Swiss farms distributed along a gradient of manage- } \\
\text { ment intensity and their elevation ranges from 605 m to 1137m. }\end{array}$ \\
\hline Data source location & Canton of Obwalden, Switzerland \\
\hline Data accessibility & Data published in Lüscher et al., 2016 \\
\hline
\end{tabular}

Data about bee and plant species richness were collected within the EU FP7 Project Biobio research program (http://www.biobio-indicator.org) and were published in Lüscher et al. (2016). Species were collected in different habitats on the farms (including linear structures). In this study, we focused on grassland habitats solely. Farm management indicators for each farm were also collected (e.g., nitrogen input). Data about management were provided by farmers in face-to-face interviews following a standardized questionnaire.

Bee species richness:

Data were collected at 19 farms located in the canton of Obwalden. The sampling was performed during the growing season in 2010, using standardized protocols (Dennis et al., 2012). Bees were sampled in a transect walk of $2 \mathrm{~m} \times 100 \mathrm{~m}$ with aerial netting for $15 \mathrm{~min}$, on three dates during good weather conditions, i.e. when conditions were dry and bright (cloud cover less than 50\%) between $10.00 \mathrm{~h}$ and $19.00 \mathrm{~h}$, with winds no stronger than Beaufort scale $4\left(7 \mathrm{~m} \mathrm{~s}^{-1}\right)$ and temperature at or above $15^{\circ} \mathrm{C}$.

Vascular plant species richness:

Vascular plants were sampled using standardized protocols during one growing season, in 2010. The vegetation surveys were undertaken in plots placed at the center of the grassland to avoid edge effects. The plots measured $10 \mathrm{~m} \times 10 \mathrm{~m}$ and were set up using survey poles with strings forming the diagonals of the square. Plots were orientated with the strings on the north-south and east-west axes. Vascular plant species were identified and recorded (except bryophytes and lichens). Their respective ground cover was estimated.

Recreation

\begin{tabular}{|l|l|}
\hline Type of data & Georeferenced photos \\
\hline How data was acquired & Flickr (a photo sharing social media website). \\
\hline Data format & Raw \\
\hline Experimental features & $\begin{array}{l}\text { A total of 17,979 images were downloaded and used to analyse how } \\
\text { many were present by grassland category and elevation, and further } \\
\text { separated by year. }\end{array}$ \\
\hline Data source location & Area of Solothurn, Switzerland. \\
\hline Data accessibility & Flickr \\
\hline
\end{tabular}

Data from the photo sharing website Flickr is freely available online and has high potential for the assessment of cultural ES. Original images were uploaded to Flickr by users, often preserving the 
geographic location of where the photo was taken. The photo locations can thus be used an indication of cultural ES, especially outdoor recreation. The data consists of the number of images that were uploaded within the grassland category between the years of 2008 and 2017 to Flickr for the study area of Solothurn, Switzerland.

The grasslands shapefile was projected from CH1903+_LV95 to GCS_WGS 1984 using the CH1903+_LV95_To_GCS_WGS_1984 geographic transformation in ArcMap v10.3. A python script was run to query the Flickr API at every $0.01 \times 0.01$ degree, capturing all points. The points were imported in ArcMap and used calculate points within each grassland and elevation types (with a 100m buffer) by year (between 2008-2017). Multiple buffer sizes between $25 \mathrm{~m}$ and $150 \mathrm{~m}$ were tested, before 100m was chosen, following Haider and Ali (2018), as they previously used this radius to gather Flickr data around the location of sites for assessment for cultural service assessment (specifically aesthetic). The number of resulting photos per $\mathrm{km}^{2}$ were calculated using the original area covered by each grassland category, rather than the buffer area. A total of 17,979 photos were analyzed in this analysis. See Table A1.

Table A1: Photos by grassland category (per $\mathrm{km}^{2}$ ) by year. Calculated using a $100 \mathrm{~m}$ buffer, with area calculation using original area size of each grassland category and two elevation levels. Lowlands are considered as grasslands below 800 masl and highlands as grasslands above 800 masl.

\begin{tabular}{|c|c|c|c|c|c|c|c|c|c|c|c|c|c|c|c|c|c|c|c|}
\hline Intensity & Elevation & 2008 & \multicolumn{2}{|c|}{2009} & \multicolumn{2}{|c|}{2010} & \multicolumn{2}{|c|}{2011} & \multicolumn{2}{|c|}{2012} & \multicolumn{2}{|c|}{2013} & \multicolumn{2}{|c|}{2014} & \multicolumn{2}{|c|}{2015} & \multicolumn{2}{|r|}{2016} & 2017 \\
\hline \multicolumn{20}{|l|}{ Meadow } \\
\hline \multirow{2}{*}{ Intensive } & Lowland & 3.64 & \multicolumn{2}{|c|}{5.06} & \multicolumn{2}{|c|}{1.95} & 4.2 & & 3.74 & \multicolumn{3}{|c|}{6.18} & 9.54 & & \multicolumn{2}{|c|}{15.61} & \multicolumn{2}{|c|}{7.35} & 6.64 \\
\hline & Highland & 9.04 & \multicolumn{2}{|c|}{2.13} & \multicolumn{2}{|c|}{1.15} & 0.7 & & 1.06 & \multicolumn{2}{|c|}{10.81} & & 5.14 & & \multicolumn{2}{|c|}{9.31} & \multicolumn{2}{|c|}{3.72} & 5.41 \\
\hline \multirow{2}{*}{ Less intensive } & Lowland & 1.75 & \multicolumn{2}{|c|}{2.28} & \multicolumn{2}{|c|}{2.46} & 1.4 & & 1.23 & \multicolumn{2}{|c|}{2.10} & & 7.72 & & \multicolumn{2}{|c|}{7.37} & \multicolumn{2}{|c|}{2.81} & 3.33 \\
\hline & Highland & 6.72 & \multicolumn{2}{|c|}{8.39} & \multicolumn{2}{|c|}{0.00} & 0.0 & & 5.04 & \multicolumn{2}{|c|}{0.00} & & 5.04 & & 3. & & & 00 & 5.04 \\
\hline & Lowland & 4.15 & 3.2 & & & 94 & 4.2 & & 3.29 & & 5.33 & & 8.29 & & 11. & & 2. & 49 & 6.64 \\
\hline Extensive & Highland & 0.88 & 5. & & 12 & & 2.8 & & 4.74 & & 3.16 & & 5.44 & & 10. & & & 86 & 7.20 \\
\hline Past & & & & & & & & & & & & & & & & & & & \\
\hline & Lowland & & & & & & & 1.8 & & 2.0 & & 6.3 & 35 & & & & & 2.83 & 3.85 \\
\hline Intensıve & Highland & & 73 & & 47 & & & 2.0 & & 2.2 & & 4.0 & 00 & & & 20 & & 2.93 & 36.66 \\
\hline & Lowland & & 35 & & 30 & & & 3.7 & & 2.2 & & 7.8 & 83 & & & & & 2.68 & 11.06 \\
\hline tensıve & Highland & 14 & & & 40 & 12 & & 3.7 & 77 & 37.4 & & 13.3 & & 18 & & & 44 & 2.83 & 7.91 \\
\hline
\end{tabular}

\section{Appendix 2: Description of the grasslands and the explanatory variables}

\section{Characteristics of the management (regime and intensity levels)}

Parcels are varied in terms of management and environmental characteristics (Table A2). Census data were acquired from the Canton of Solothurn (http://gelan.ch) and are publically available. The data set provides georeferenced information across the Canton about the location of the parcels and some of their management characteristics, i.e., management regime and the level of intensity of their management. Moreover, the information has been validated by the farmers and is being used to distribute potential direct payments. We selected parcels of grasslands only.

The census data classify grasslands into five classes, based on their management: two regimes (pasture and meadow) and two to three intensity levels (intensive, less intensive and extensive meadows and intensive and extensive pastures). We used scientific literature to further characterize these five classes, according to their management (Blüthgen et al., 2012), e.g. in terms of amount of fertilizer, frequency of mowing or grazing. Here, we defined meadows as grasslands that are harvested predominantly by mowing over the last years or since sward establishment if it is younger than five years (Peeters et al., 2014). In agreement with the census set, meadows were divided into three levels of intensity: intensive, less intensive and extensive. Pastures were defined as grasslands that have 
been predominantly grazed over the last five years or since sward establishment if it is younger than five years. In concordance with the census database, we distinguished intensive from extensive pastures. We assumed that grasslands are well-balanced in species composition (i.e. they comprise 50 to $70 \%$ of grass; Huguenin-Elie al., 2017). The use of these two parameters (management regime and management intensity) resulted in the establishment of five grassland categories (Table A2).

Elevation affects various variables related to environmental characteristics (e.g. species richness, productivity) and to management intensity (e.g. yield, number of cuts; (Bergamini et al., 2001; Bühler and Schmid, 2001; Grandchamp et al., 2005; Güsewell et al., 2012; Jacot et al., 2000). We decided to distinguish two elevational classes. Despite an abundant literature, there is no consensus on thresholds to delimit elevational class. Based on previous studies, biogeographical knowledge and taking into account statistical constraints related to the need for a minimum number of observations per class, we decided to differentiate two elevational classes: lowlands (<800m m.a.s.l.) and highlands (> $800 \mathrm{~m}$ m.a.s.l.). We used this further distinction between grassland categories to model the recreational service.

Table A2. Distribution of the grasslands categories. In the lowland, many intensive meadows are not permanent grasslands but are included in a system of crop rotation and therefore we did not include these rotational meadows. When applicable, in brackets, the range of the values of the variables.

\begin{tabular}{|c|c|c|c|c|c|}
\hline & \multicolumn{3}{|l|}{ Meadows } & \multicolumn{2}{|l|}{ Pasture } \\
\hline & Extensive & Less intensive & Intensive & Extensive & Intensive \\
\hline Number of parcels & 6462 & 312 & 6900 & 1137 & 2572 \\
\hline Area (ha) & $\begin{array}{ll}3350 & (0.001- \\
9.6) & \end{array}$ & $156(0.001-96)$ & $\begin{array}{ll}6647 & (0.0003- \\
21.1) & \end{array}$ & $\begin{array}{l}1562 \quad(0.01- \\
25.9) \quad\end{array}$ & $\begin{array}{l}3764 \quad(0.0003- \\
23.1)\end{array}$ \\
\hline Elevation $(\mathrm{m})$ & $556(324-1351)$ & $\begin{array}{ll}585 & (349- \\
1269)\end{array}$ & $594(305-1373)$ & 705 (335-1370) & $619(325-1373)$ \\
\hline Slope (\%) & $13(0-87)$ & $15(0-56)$ & $15(0-87)$ & $24(0-75)$ & $17(0-77)$ \\
\hline Distance to the forest $(\mathrm{m})$ & $226(0-2300)$ & $120(0-985)$ & $166(0-2336)$ & $93(0-2234)$ & $165(0-2266)$ \\
\hline $\begin{array}{l}\text { Main class of soil suitabil- } \\
\text { ity }\end{array}$ & 1 & 4 & 4 & 5 & 5 \\
\hline
\end{tabular}

Environmental characterization of the parcels and their surrounding landscape in the canton of Solothurn

The parcels of grasslands are georeferenced. Therefore, in a GIS, it is possible to calculate their area and to overlay their limits with other environmental variables to characterize the biophysical attributes of each parcel and its surrounding landscape (Table A3). To characterize the parcels, we used information related to topography (Aster DEM, available on https://gdex.cr.usgs.gov/gdex/). We calculated average elevation and slope, using the ArcGIS Spatial Analysis toolbox. We also used the soil classification (FOAG, 2005) to determine the dominant soil class. Landscape characteristics, distance to forests, Simpson's diversity and patch richness (metrics of landscape structure), were calculated from Corine Land Cover (available on https://land.copernicus.eu/pan-european/corine-landcover/clc-2012/view).

Table A3. Characterization of the parcels of Solothurn, based on their environmental attributes and on the surrounding landscape (example of 20 parcels).

\begin{tabular}{|llrrrrrr|}
\hline Regime & Intensity & $\begin{array}{c}\text { Soil } \\
\text { suitability }\end{array}$ & $\begin{array}{c}\text { Slope } \\
(\%)\end{array}$ & $\begin{array}{c}\text { Elevation } \\
(\mathrm{m})\end{array}$ & $\begin{array}{c}\text { Parcel } \\
\text { Area (ha) }\end{array}$ & $\begin{array}{c}\text { Distance } \\
\text { to forest (m) }\end{array}$ & $\begin{array}{c}\text { Simpson } \\
\text { Diversity }\end{array}$ \\
\hline Pasture & Extensive & 1 & 6 & 404 & 2.47 & 918.65 & 0 \\
Meadow & Extensive & 1 & 3 & 467 & 0.19 & 1215.46 & 0 \\
Meadow & Intensive & 5 & 20 & 972 & 5.35 & 443.54 & 0.26
\end{tabular}




\begin{tabular}{|c|c|c|c|c|c|c|c|c|}
\hline Meadow & Extensive & 3 & 6 & 479 & 1.00 & 1114.96 & 0 & 1 \\
\hline Meadow & Extensive & 2 & 19 & 398 & 0.26 & 128.77 & 0.18 & 3 \\
\hline Meadow & Extensive & 1 & 2 & 434 & 1.20 & 1632.10 & 0.27 & 2 \\
\hline Meadow & Intensive & 2 & 8 & 630 & 0.55 & 806.07 & 0.23 & 2 \\
\hline Meadow & Extensive & 3 & 2 & 436 & 0.26 & 1713.24 & 0.16 & 2 \\
\hline Meadow & Intensive & 1 & 12 & 499 & 0.64 & 238.72 & 0.00 & 1 \\
\hline Pasture & Intensive & 5 & 8 & 626 & 0.26 & 68.19 & 0 & 1 \\
\hline Meadow & Intensive & 4 & 5 & 643 & 0.08 & 1985.28 & 0.43 & 2 \\
\hline Meadow & Extensive & 1 & 5 & 460 & 0.09 & 1511.53 & 0.43 & 2 \\
\hline Pasture & Intensive & 5 & 7 & 469 & 0.59 & 2051.49 & 0.00 & 1 \\
\hline Meadow & Intensive & 5 & 10 & 590 & 0.09 & 1359.37 & 0.43 & 2 \\
\hline Meadow & Intensive & 4 & 8 & 500 & 0.72 & 881.82 & 0.12 & 2 \\
\hline Meadow & Less Intensive & 4 & 6 & 479 & 0.01 & 15.17 & 0.24 & 2 \\
\hline Meadow & Intensive & 2 & 2 & 460 & 1.09 & 634.54 & 0.16 & 2 \\
\hline Meadow & Intensive & 3 & 5 & 699 & 1.80 & 968.27 & 0 & 1 \\
\hline Meadow & Extensive & 1 & 3 & 476 & 0.24 & 2458.71 & 0.25 & 2 \\
\hline Meadow & Extensive & 3 & 7 & 668 & 0.20 & 698.75 & 0. & 1 \\
\hline
\end{tabular}

\section{Appendix 3: $\mathrm{C}$ in fertilization}

To calculate the $C$ in fertilizers ( $C$ imported in the system), we first estimated the amounts of fertilizers applied on each parcel. We used the recommended amounts of nitrogen fertilizers presented in Huguenin-Elie et al. (2017) for each of the grassland categories (management regime * intensity) and per unit of yield. $\mathrm{N}$ fertilization recommendations ranged from 1.1 to $1.3 \mathrm{~kg} \mathrm{~N} / \mathrm{dt} \mathrm{DM}$ for intensive grasslands (meadows or pastures) and from 0.4 to $0.6 \mathrm{~kg} \mathrm{~N} / \mathrm{dt} \mathrm{DM}$ for less intensive meadows. Extensive grasslands are not fertilized at all in Switzerland. For each parcel, we thus multiplied the yield by the recommended amount of $\mathrm{N}$ fertilizer. Then, we applied the ratio $\mathrm{C} / \mathrm{N}$ of 2.1 to reveal the amount of $\mathrm{C}$ contained in the organic fertilization. The $\mathrm{C} / \mathrm{N}$ ratio was estimated from the data available from for two observation sites used to model the NEE (Chamau and Früebüel; Swiss flux towers).

\section{Appendix 4: Additional results from the statistical and spatial modelling}

Summary statistics of ES variables with management regime and intensity levels

The calculation of grassland ES for different grasslands categories showed the variation between regimes and intensity levels derived from empirical datasets (Table A4).

Table A4. Variations in measured ES indicators within the intensity levels of both meadows and pastures. We displayed the statistics for the time series of the indicator of outdoor recreation (number of pictures).

\begin{tabular}{|c|c|c|c|c|c|c|}
\hline & & \multicolumn{3}{|c|}{ Meadow } & \multicolumn{2}{|c|}{ Pasture } \\
\hline & & Intensive & Less intensive & Extensive & Intensive & Extensive \\
\hline \multirow{6}{*}{$\begin{array}{l}\text { Yield } \\
\text { t/ha }\end{array}$} & Min & 6.37 & 3.15 & 1.42 & 5.66 & 1.11 \\
\hline & Median & 10.61 & 5.35 & 2.69 & 9.01 & 1.81 \\
\hline & Mean & 10.84 & 5.32 & 2.64 & 9.15 & 1.82 \\
\hline & Max & 13 & 6.4 & 3.05 & 11 & 2.4 \\
\hline & Standard deviation & 1.34 & 0.67 & 0.33 & 1.28 & 0.29 \\
\hline & Observations* & 6411 & 303 & 5992 & 2433 & 1100 \\
\hline \multirow{6}{*}{$\begin{array}{l}\text { C exchange } \\
\text { t C / (ha * year) }\end{array}$} & Min & -1.7 & -5.1 & -2.8 & -4.3 & -4.4 \\
\hline & Median & -0.8 & -0.9 & -1.7 & -2.4 & -1.2 \\
\hline & Mean & -0.5 & -1.3 & -1.7 & -2.5 & -1.4 \\
\hline & $\operatorname{Max}$ & 1.4 & 0.2 & -0.2 & -0.8 & 1 \\
\hline & Standard deviation & 1.1 & 1.7 & 0.7 & 0.9 & 1.6 \\
\hline & Observations & 13 & 16 & 18 & 19 & 17 \\
\hline
\end{tabular}




\begin{tabular}{|c|c|c|c|c|c|c|}
\hline \multirow{6}{*}{$\begin{array}{l}\text { Bee species } \\
\text { richness } \\
\text { (number) }\end{array}$} & Min & 1 & 3 & 2 & 3 & 7 \\
\hline & Median & 3 & 4 & 5 & 3.5 & 7.5 \\
\hline & Mean & 3.6 & 4.8 & 5.1 & 4.0 & 7.5 \\
\hline & Max & 7 & 7 & 7 & 6 & 8 \\
\hline & Standard deviation & 1.6 & 1.5 & 1.6 & 1.26 & 0.58 \\
\hline & Observations & 17 & 11 & 12 & 6 & 7 \\
\hline \multirow{6}{*}{$\begin{array}{l}\text { Plant species } \\
\text { richness } \\
\text { (number) }\end{array}$} & Min & 22 & 29 & 36 & 20 & 44 \\
\hline & Median & 26 & 38 & 48 & 32 & 46 \\
\hline & Mean & 27.4 & 38.5 & 49.8 & 30.2 & 48.4 \\
\hline & Max & 35 & 50 & 70 & 38 & 57 \\
\hline & Standard deviation & 4.2 & 6.7 & 9 & 6.9 & 5.3 \\
\hline & Observations & 17 & 11 & 12 & 6 & 7 \\
\hline \multirow{6}{*}{$\begin{array}{l}\text { Number of } \\
\text { photos }\end{array}$} & Min & 0.71 & 0.63 & 0.91 & 1.17 & 2.23 \\
\hline & Median & 8.31 & 4.2 & 6.82 & 4.39 & 7.02 \\
\hline & Mean & 8.41 & 4.31 & 6.81 & 8.08 & 5.57 \\
\hline & Max & 15.6 & 7.66 & 12.43 & 36.49 & 37.03 \\
\hline & Standard deviation & 3.93 & 1.88 & 2.86 & 5.62 & 5.29 \\
\hline & Observations & 20 & 20 & 20 & 20 & 20 \\
\hline
\end{tabular}

*Because yield data were not measured on the field, the statistics summary for this ES was calculated for the grasslands of Solothurn.

\section{Summary of the final models}

To model the $\mathrm{C}$ sequestration, we first built a linear model based on $\mathrm{CO}_{2}$ flux data collected at flux towers in temperate grassland sites across Europe to estimate the net exchange $N E E_{p}$ (Eq. 1a). We selected the final model, through a variable selection procedure and estimated the parameters.

$N E E=\propto_{0}+\propto_{1} \cdot$ Regime $+\propto_{2} \cdot$ Intensity $+\propto_{3} \cdot$ Elevation $+\propto_{4} \cdot($ Intensity $\cdot$ Elevation $)$

(Eq. 1a)

Multiple $\mathrm{R}^{2}$ : 0.40; Adjusted $\mathrm{R}^{2}$ : 0.35; $p$-value: $<0.001$

\begin{tabular}{|l|l|}
\hline Coefficients $(\propto)$ : & Estimate \\
\hline (Intercept) & -0.7906 \\
\hline Regime-Pasture & -0.1441 \\
\hline Elevation & -0.0018 \\
\hline Intensity-Intensive & 0.1414 \\
\hline Intensity-Less Intensive & -3.602 \\
\hline Elevation: Intensity-Intensive & 0.0001 \\
\hline Elevation: Intensity-Less Intensive & 0.0043 \\
\hline
\end{tabular}

We also estimated the $C$ exported from the grassland systems ( $C_{\text {export }}$ through harvesting; Eq.1d for pastures) for each parcel.

$C_{\text {export }}=-0.01+0.41 \cdot$ Yield

Multiple $\mathrm{R}^{2}$ : 0.99; Adjusted $\mathrm{R}^{2}$ : 0.99; $p$-value: $<0.001$

\begin{tabular}{|c|c|}
\hline Coefficients $(\partial)$ : & Estimate \\
\hline (Intercept) & -0.01146 \\
\hline Yield & 0.409002 \\
\hline
\end{tabular}

Vascular plant and bee species richness

We implemented regression analyses to model bee and vascular plant species richness (Eq. 2).

Species richness $=\gamma_{0}+\gamma_{X} \cdot X$, 
with Species richness, the richness in either bees or plants, $X$ a set of explanatory variables about the management, its environmental characteristics and the characteristics of the surrounding landscape of a specific parcel.

The final model for the bees presented the following variables:

Bee Species Richness $=\gamma_{0}+\gamma_{1} \cdot$ Regime $+\gamma_{2} \cdot$ INtensity $+\gamma_{3} \cdot$ Distance to the forest $+\gamma_{4} \cdot$ Slope

Multiple $\mathrm{R}^{2}$ : 0.41; Adjusted $\mathrm{R}^{2}: 0.35 ; p$-value: $<0.001$

\begin{tabular}{|l|l|}
\hline Coefficients (Y): & \multicolumn{1}{|c|}{ Estimate } \\
\hline (Intercept) & 7.658406 \\
\hline Regime-pasture & 1.139367 \\
\hline Intensity-Intensive & -1.243324 \\
\hline Intensity-Less Intensive & -0.079226 \\
\hline Distance to forest & -0.003152 \\
\hline Slope & -0.108794 \\
\hline
\end{tabular}

The final model for the vascular plants presented the following variables:

Plant Species Richness $=\gamma_{0}^{\prime}+\gamma_{11} \cdot$ Regime $+\gamma_{2}^{\prime} \cdot$ Intensity $+\gamma_{3}^{\prime} \cdot$ Elevation $+\gamma_{4}^{\prime} \cdot$ Slope

Multiple $\mathrm{R}^{2}$ : 0.75; Adjusted $\mathrm{R}^{2}: 0.72 ; p$-value: $<0.001$

\begin{tabular}{|c|c|}
\hline Coefficients $\left(\gamma^{\prime}\right)$ : & Estimate \\
\hline (Intercept) & 62.592872 \\
\hline RegimePasture & 3.186714 \\
\hline IntensityIntensive & -18.651679 \\
\hline IntensityLess Intensive & -7.149257 \\
\hline Elevation & -0.015758 \\
\hline Slope & -0.187069 \\
\hline
\end{tabular}

Maps of the ES indicators 


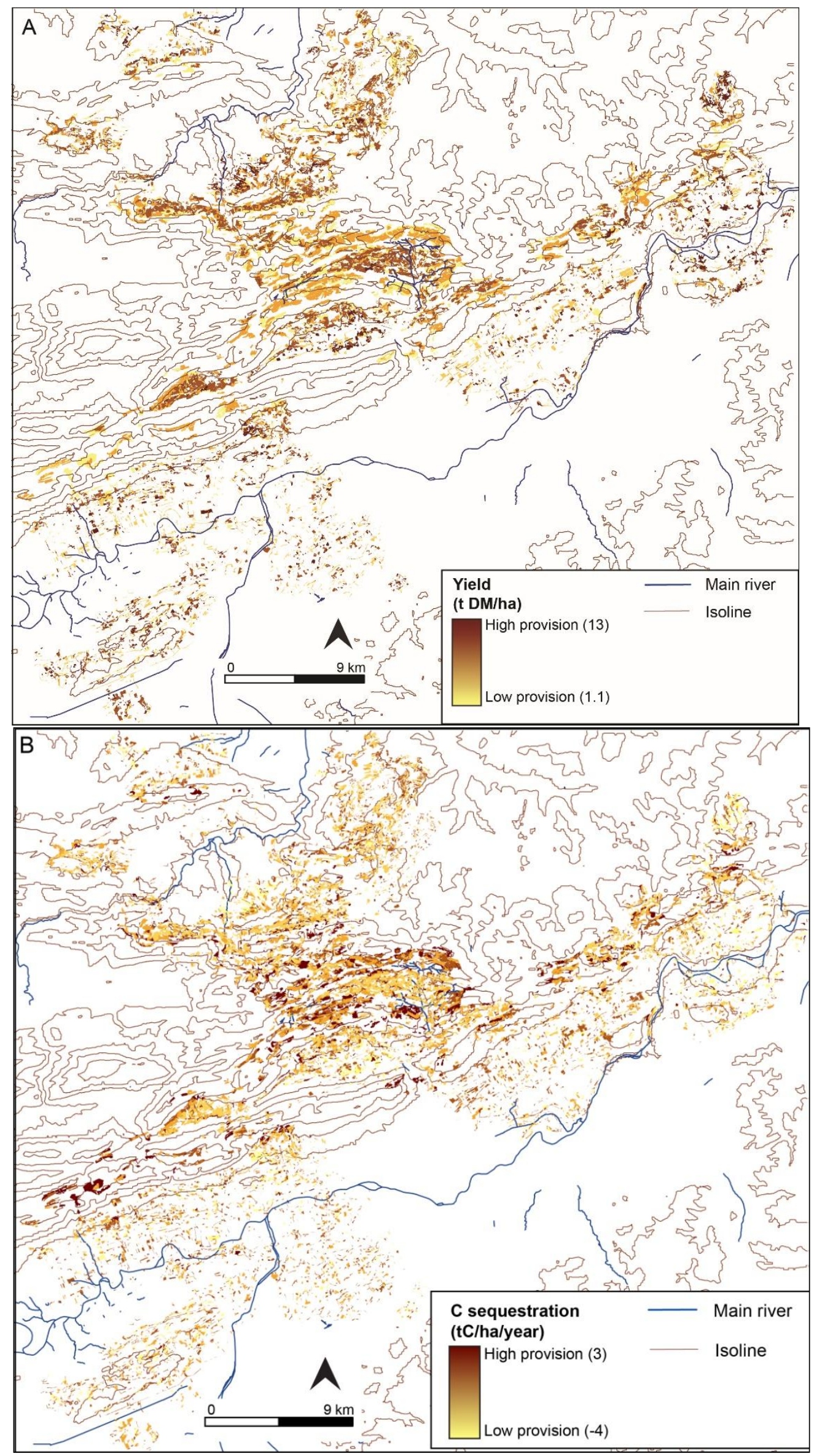




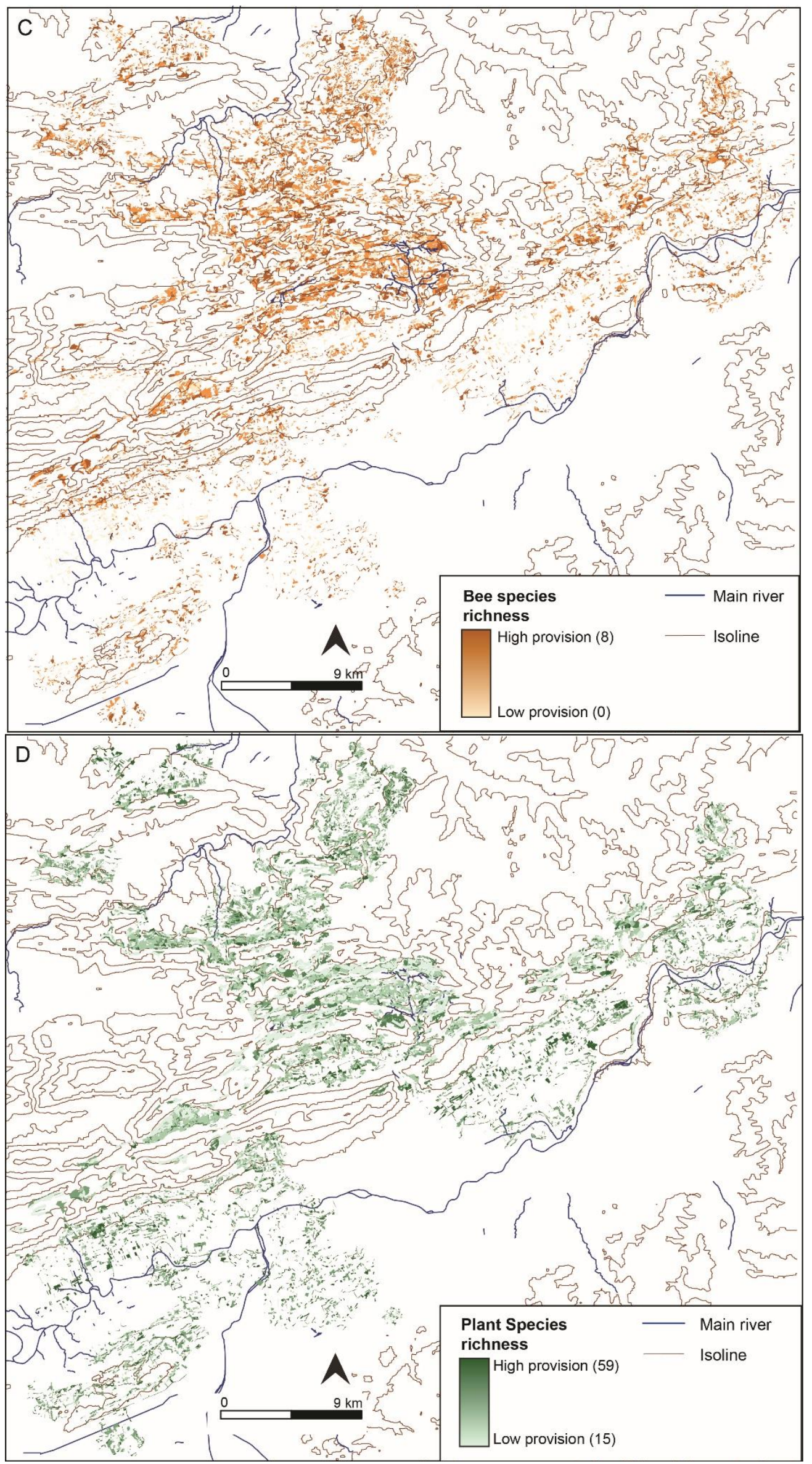




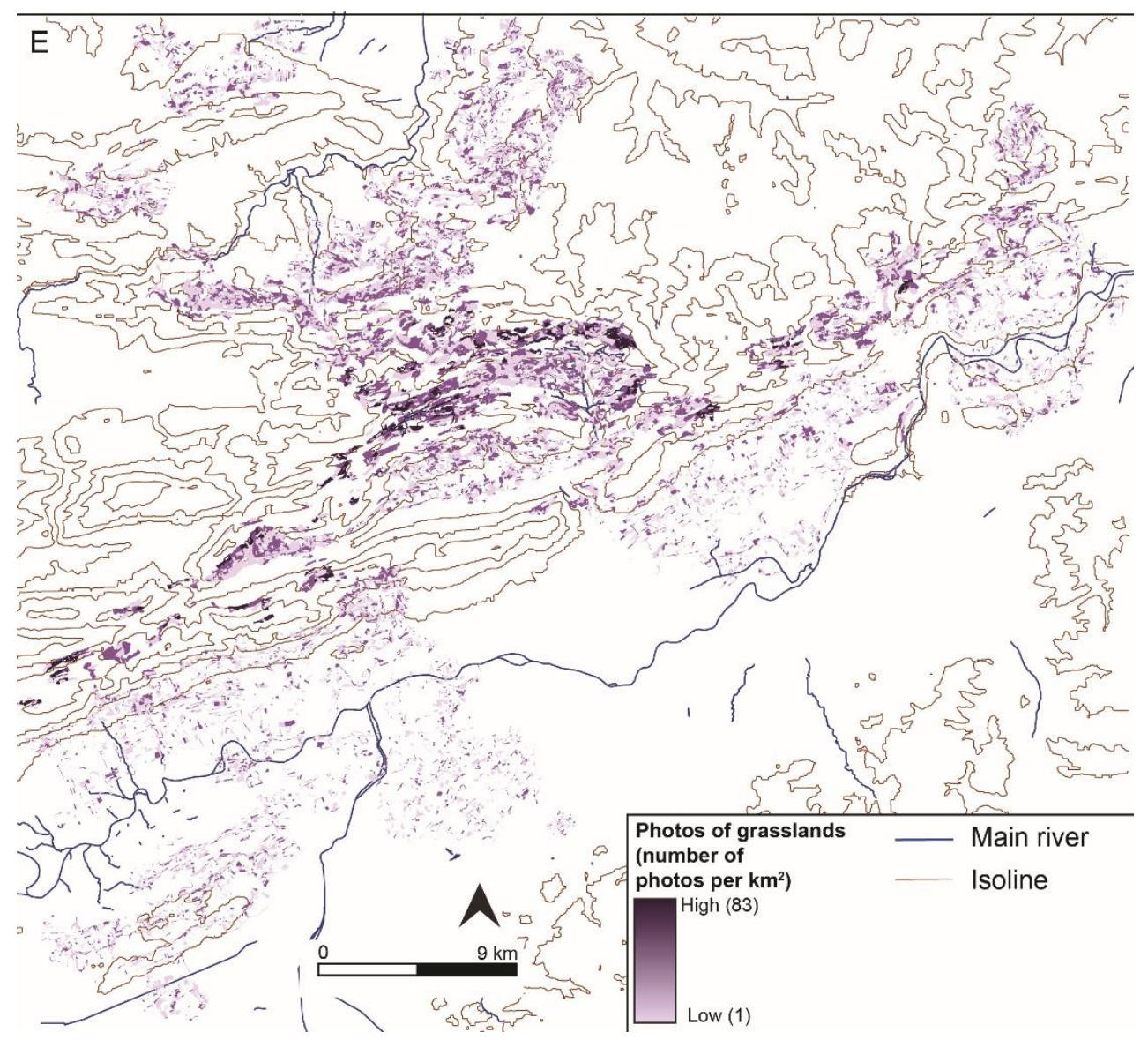

Figure A1. Spatial distribution of the ES in Solothurn. A. Yield; B. C sequestration. Positive values reveal $C$ sinks whereas negative values indicate $C$ sources; $C$. Bee species richness; $D$. Plant species richness and $E$. Number of photos. In brackets, lowest and highest value of the ES provision. 


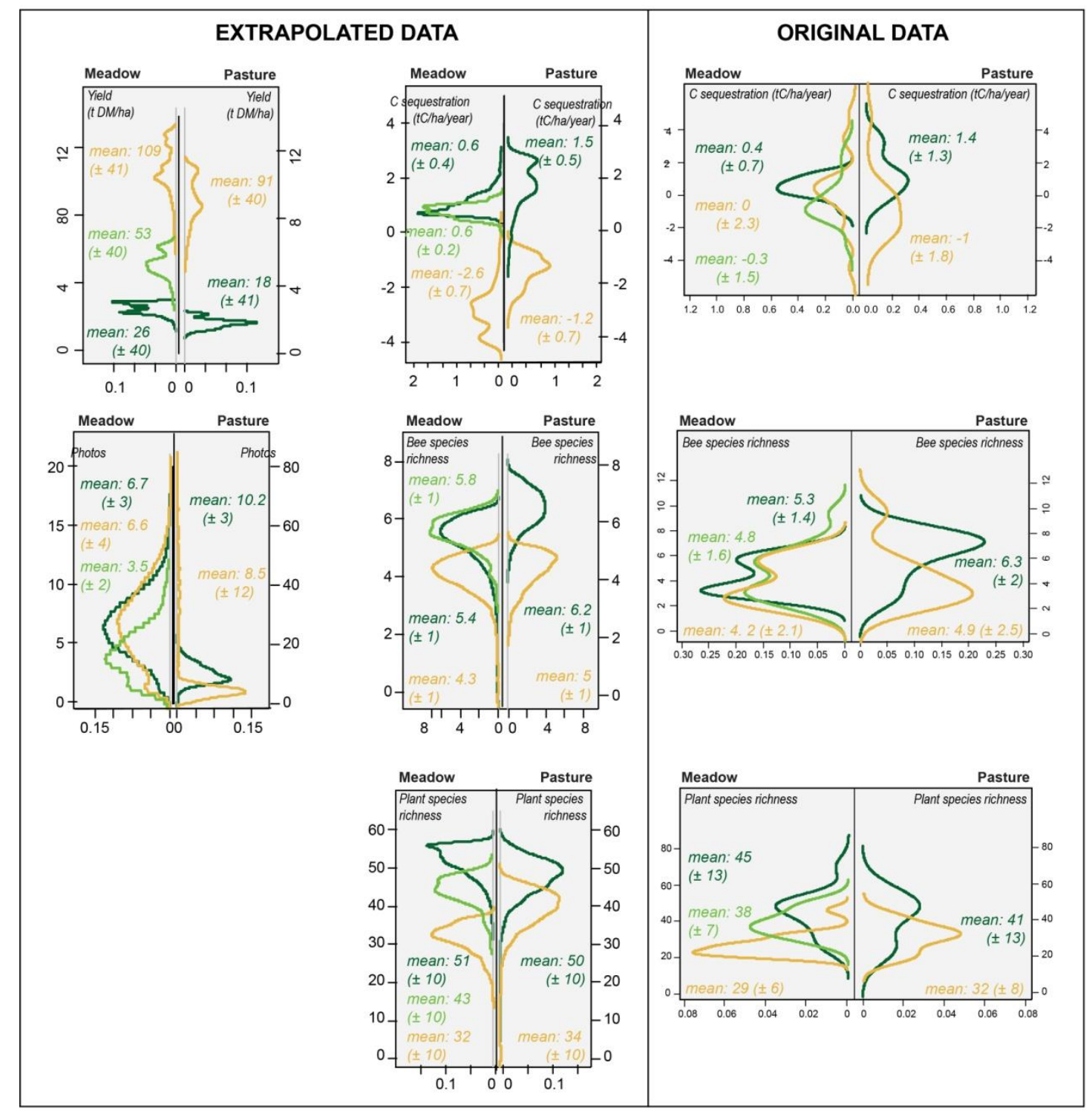

Figure A2. Density functions demonstrate the probability of the expected ES provision under a specific management.

Table A6. Results of the Kruskall-Wallis tests

\begin{tabular}{|l|l|l|}
\hline \multirow{2}{*}{} & \multicolumn{2}{|c|}{ Kruskall-Wallis } \\
\cline { 2 - 3 } & Chi-squared & p-value \\
\hline Yield & 14251 & $<0.001$ \\
\hline C sequestration & 14870 & $<0.001$ \\
\hline Bee species richness & 8249.7 & $<0.001$ \\
\hline Plant species richness & 13217 & $<0.001$ \\
\hline Number of photos & 1926 & $<0.001$ \\
\hline
\end{tabular}

\section{Appendix 4: Additional results on multiple ES assessment}

Table A7. Correlation table (Pearson's correlations) between the five modelled ES, for meadows and pastures.

\begin{tabular}{|l|l|l|l|l|l|}
\hline MEADOW & Yield & C sequestration & $\begin{array}{l}\text { Bee spe- } \\
\text { cies rich- } \\
\text { ness }\end{array}$ & $\begin{array}{l}\text { Plant spe- } \\
\text { cies rich- } \\
\text { ness }\end{array}$ & $\begin{array}{l}\text { Number of } \\
\text { photos }\end{array}$ \\
\hline Forage provision & 1 & & & & \\
\hline C sequestration & -0.99 & 1 & & & \\
\hline Pollination & -0.55 & 0.56 & 1 & & \\
\hline Biodiversity & -0.85 & 0.77 & 0.49 & 1 & \\
\hline
\end{tabular}




\begin{tabular}{|l|l|l|l|l|l|}
\hline Recreation & -0.01 & 0.01 & 0 & 0.02 & 1 \\
\hline PASTURE & Yield & C sequestration & $\begin{array}{l}\text { Bee spe- } \\
\text { cies rich- } \\
\text { ness }\end{array}$ & $\begin{array}{l}\text { Plant spe- } \\
\text { cies rich- } \\
\text { ness }\end{array}$ & $\begin{array}{l}\text { Number of } \\
\text { photos }\end{array}$ \\
\hline Forage provision & 1 & & & & \\
\hline C sequestration & -0.98 & 1 & & & \\
\hline Pollination & -0.58 & 0.55 & 1 & & \\
\hline Biodiversity & -0.70 & 0.56 & 0.58 & 1 & \\
\hline Recreation & -0.24 & 0.33 & 0.01 & -0.20 & 1 \\
\hline
\end{tabular}

Table A8. ES overall score within the grassland categories, for all parcels of agricultural grasslands of the Canton of Solothurn.

\begin{tabular}{|l|l|l|l|l|l|}
\hline & & \multicolumn{4}{|l|}{ ES score } \\
\hline Regime & Intensity level & Min & Max & Mean & Standard deviation \\
\hline \multirow{3}{*}{ Meadow } & Intensive & 8 & 16 & 12 & 1.5 \\
\cline { 2 - 7 } & Less Intensive & 8 & 16 & 12 & 1.6 \\
\cline { 2 - 7 } & Extensive & 9 & 18 & 13 & 1.6 \\
\hline \multirow{2}{*}{ Pasture } & Intensive & 8 & 16 & 12 & 1.4 \\
\cline { 2 - 6 } & Extensive & 10 & 17 & 14 & 1.1 \\
\hline
\end{tabular}

\section{Online appendix}

$\mathrm{R}$ codes

\section{References}

Bergamini, A., Peintinger, M., Schmid, B., Urmi, E., 2001. Effects of management and altitude on bryophyte species diversity and composition in montane calcareous fens. Flora 196, 180-193. Blüthgen, N., Dormann, C., Prati, D., Klaus, V., Kleinebecker, T., Hölzel, N., Alt, F., Boch, S., Gockel, S., Hemp, A., Müller, J., Nieschulze, J., Renner, S., Schöning, I., Schumacher, U., Socher, S., Wells, K., Birkhofer, K., Buscot, F., Oelmann, Y., Rothenwöhrer, C., Scherber, C., Tscharntke, T., Weiner, C., Fischer, M., Kalko, E., Linsenmair, K., Schulze, E., Weisser, W., 2012. A quantitative index of land-use intensity in grasslands: Integrating mowing, grazing and fertilization. Basic and Applied Ecology 13, 207-220.

Bühler, C., Schmid, B., 2001. The Influence of Management Regime and Altitude on the Population Structure of Succisa pratensis: Implications for Vegetation Monitoring. Journal of Applied Ecology 38, 689-698.

Dennis, P., Bogers, M.M.B., Bunce, R.G.H., Herzog, F., Jeanneret, P., Geijzendorffer, I.R., Jongman, R.H.G., 2012. Biodiversity in organic and low-input farming systems : handbook for recording key indicators. Alterra, Wageningen-UR, Wageningen.

FOAG, 2005. Cartes des aptitudes des sols de la Suisse.

Grandchamp, A.-C., Bergamini, A., Stofer, S., Niemelä, J., Duelli, P., Scheidegger, C., 2005. The influence of grassland management on ground beetles (Carabidae, Coleoptera) in Swiss montane meadows. Agriculture, Ecosystems \& Environment 110, 307-317.

Güsewell, S., Peter, M., Birrer, S., 2012. Altitude modifies species richness-nutrient indicator value relationships in a country-wide survey of grassland vegetation. Ecological Indicators 20, 134-142. Haider, C.M.R., Ali, M.E., 2018. Can We Predict the Scenic Beauty of Locations from Geo-tagged Flickr Images?, 23rd International Conference on Intelligent User Interfaces. ACM, Tokyo, Japan, pp. 653657.

Huguenin-Elie, O., Mosimann, E., Schlegel, P., Lüscher, A., Kessler, W., Jeangros, B., 2017. Fertilisation des herbages. Recherche agronomique Suisse 8, 143-165.

Jacot, K.A., Lüscher, A., Nösberger, J., Hartwig, U.A., 2000. Symbiotic N2 fixation of various legume species along an altitudinal gradient in the Swiss Alps. Soil Biology and Biochemistry 32, 1043-1052. 
Lüscher, G., Ammari, Y., Andriets, A., Angelova, S., Arndorfer, M., Bailey, D., Balázs, K., Bogers, M., Bunce, R.G.H., Choisis, J.-P., Dennis, P., Díaz, M., Dyman, T., Eiter, S., Fjellstad, W., Fraser, M., Friedel, J.K., Garchi, S., Geijzendorffer, I.R., Gomiero, T., González-Bornay, G., Guteva, Y., Herzog, F., Jeanneret, P., Jongman, R.H.G., Kainz, M., Kwikiriza, N., López Díaz, M.L., Moreno, G., NicholasDavies, P., Nkwiine, C., Opio, J., Paoletti, M.G., Podmaniczky, L., Pointereau, P., Pulido, F., Sarthou, J.P., Schneider, M.K., Sghaier, T., Siebrecht, N., Stoyanova, S., Wolfrum, S., Yashchenko, S., Albrecht, H., Báldi, A., Belényesi, M., Benhadi-Marin, J., Blick, T., Buholzer, S., Centeri, C., Choisis, N., Cuendet, G., De Lange, H.J., Déjean, S., Deltshev, C., Díaz Cosín, D.J., Dramstad, W., Elek, Z., Engan, G., Evtushenko, K., Falusi, E., Finch, O.-D., Frank, T., Gavinelli, F., Genoud, D., Gillingham, P.K., Grónás, V., Gutiérrez, M., Häusler, W., Heer, X., Hübner, T., Isaia, M., Jerkovich, G., Jesus, J.B., Kakudidi, E., Kelemen, E., Koncz, N., Kovacs, E., Kovács-Hostyánszki, A., Last, L., Ljubomirov, T., Mandery, K., Mayr, J., Mjelde, A., Muster, C., Nascimbene, J., Neumayer, J., Ødegaard, F., Ortiz Sánchez, F.J., Oschatz, M.L., Papaja-Hülsbergen, S., Paschetta, M., Pavett, M., Pelosi, C., Penksza, K., Pommeresche, R., Popov, V., Radchenko, V., Richner, N., Riedel, S., Scullion, J., Sommaggio, D., Szalkovszki, O., Szerencsits, E., Trigo, D., Vale, J., van Kats, R., Vasilev, A., Whittington, A.E., Wilkes-Allemann, J., Zanetti, T., 2016. Farmland biodiversity and agricultural management on 237 farms in 13 European and two African regions. Ecology 97, 1625-1625.

Peeters, A., Beaufoy, G., Canals, R.M., De Vliegher, A., Huyghe, C., Isselstein, J., Jones, G., Kessler, W., Kirilov, A., Mosquera Losada, M.R., Nilsdotter-Linde, N., Parente, G., Peyraud, J.-L., Pickert, J., Plantureux, S., Porqueddu, C., Rataj, D., Stypinski, P., Tonn, B., van del Pol-van Dasselaar, A., Vintu, V., Wilkins, R.J., 2014. Grassland term definitions and classifications adapted to the diversity of European grassland-based systems, 25. General Meeting of the European Grassland Federation. Institute of Biological, Environmental and Rural Sciences (IBERS), Aberystwyth, United Kingdom, p. $897 \mathrm{p}$. 


\section{Appendix}

Appendix 1: ES variables

Yield

\begin{tabular}{|l|l}
\hline Type of data & Parameters of linear regressions
\end{tabular}

\begin{tabular}{l|l} 
How data was acquired & Equations described in Huguenin-Elie et al. 2017
\end{tabular}

Such equations are crucial to estimate yields in the Swiss context if there are no field data available. The equations reported in Huguenin-Elie et al. (2017)were used to calculate the average yield for the elevation concerned in Switzerland. For each management regime and intensity level, an equation links elevation to the yields. Below 500 m elevation, the yield does not vary significantly with elevation; the estimated yield is therefore equivalent to that calculated for an elevation at $500 \mathrm{~m}$. All equations are based on field work.

Net $\mathrm{CO}_{2}$ ecosystem exchange

\begin{tabular}{|l|l|}
\hline Type of data & Quality-controlled ecosystem $\mathrm{CO}_{2}$ fluxes \\
\hline How data was acquired & Field work \\
\hline Data format & Raw \\
\hline Experimental features & In-situ eddy covariance measurements at ecosystem scale globally \\
\hline Data source location & Site locations are given with their official identifier in brackets. \\
& Switzerland: Chamau (CH-Cha), Früebüel (CH-Fru), Oensingen (CH-Oe1); \\
& Denmark: Enghave (DK-Eng), Rimi (DK-Lva); France: Laqueuille extensive \\
& (FR-Lq2), Laqueuille intensive (FR-Lq1), Lusignan (FR-Lus); Germany: \\
& Grillenburg (DE-Gri), Mehrstedt 2 (DE-Me2), Rollesbroich (DE-RuR); Hungary: \\
& Bugac (HU-Bug), Matra (HU-Mat); Ireland: Dripsey (IE-Dri); Italy: Monte \\
& Bondone (IT-Mbo); The Netherlands: Cabauw (NL-Ca1); UK: Easter Bush (UK- \\
& EBu) \\
\hline Data accessibility & Public repositories, available at European Fluxes Database Cluster \\
& (http://gaia.agraria.unitus.it/home) and FLUXNET2015 dataset \\
& (http://fluxnet.fluxdata.org/data/fluxnet2015-dataset) \\
\hline
\end{tabular}

The Fluxnet database provides data on net ecosystem $\mathrm{CO}_{2}$ fluxes and further atmospheric variables in grasslands (among other ecosystem types) around the world. Measurements of $\mathrm{CO}_{2}$ fluxes can serve as inputs into models that predict the cycling of carbon, to detect the trends in climate, greenhouse gases and to understand how and why atmospheric state variables may vary across space.

Net ecosystem $\mathrm{CO}_{2}$ exchange was measured using flux tower stations in temperate grasslands across the world. Some data were available online, other were requested from the person responsible for the respective station.

We used daily values derived from half-hourly data for the Net Ecosystem Exchange of $\mathrm{CO}_{2}$ (USTAR Threshold; VUT) measured by eddy-covariance. An indicator of quality, ranging from 0 to 1 , is associated with the data. We excluded the data whose values were below a quality control value of 0.66 and rejected the time series when it was not gapfilled. From the half-hourly data, we calculated the cumulative sum per year.

Bee and plant species richness

\begin{tabular}{|l|l|}
\hline Type of data & Biodiversity survey \\
\hline How data was acquired & Field work \\
\hline Data format & Raw \\
\hline
\end{tabular}




\begin{tabular}{|l|l|}
\hline Experimental features & $\begin{array}{l}\text { Data were collected at 19 Swiss farms distributed along a gradient of manage- } \\
\text { ment intensity and their elevation ranges from } 605 \mathrm{~m} \text { to } 1137 \mathrm{~m} .\end{array}$ \\
\hline Data source location & Canton of Obwalden, Switzerland \\
\hline Data accessibility & Data published in Lüscher et al., 2016 \\
\hline
\end{tabular}

Data about bee and plant species richness were collected within the EU FP7 Project Biobio research program (http://www.biobio-indicator.org) and were published in Lüscher et al. (2016). Species were collected in different habitats on the farms (including linear structures). In this study, we focused on grassland habitats solely. Farm management indicators for each farm were also collected (e.g., nitrogen input). Data about management were provided by farmers in face-to-face interviews following a standardized questionnaire.

\section{Bee species richness:}

Data were collected at 19 farms located in the canton of Obwalden. The sampling was performed during the growing season in 2010, using standardized protocols (Dennis et al., 2012). Bees were sampled in a transect walk of $2 \mathrm{~m} \times 100 \mathrm{~m}$ with aerial netting for $15 \mathrm{~min}$, on three dates during good weather conditions, i.e. when conditions were dry and bright (cloud cover less than $50 \%$ ) between $10.00 \mathrm{~h}$ and $19.00 \mathrm{~h}$, with winds no stronger than Beaufort scale $4\left(7 \mathrm{~m} \mathrm{~s}^{-1}\right)$ and temperature at or above $15^{\circ} \mathrm{C}$.

\section{Vascular plant species richness:}

Vascular plants were sampled using standardized protocols during one growing season, in 2010. The vegetation surveys were undertaken in plots placed at the center of the grassland to avoid edge effects. The plots measured $10 \mathrm{~m} \times 10 \mathrm{~m}$ and were set up using survey poles with strings forming the diagonals of the square. Plots were orientated with the strings on the north-south and east-west axes. Vascular plant species were identified and recorded (except bryophytes and lichens). Their respective ground cover was estimated.

\section{Recreation}

\begin{tabular}{|l|l|}
\hline Type of data & Georeferenced photos \\
\hline How data was acquired & Flickr (a photo sharing social media website). \\
\hline Data format & Raw \\
\hline Experimental features & $\begin{array}{l}\text { A total of 17,979 images were downloaded and used to analyse how } \\
\text { many were present by grassland category and elevation, and further } \\
\text { separated by year. }\end{array}$ \\
\hline Data source location & Area of Solothurn, Switzerland. \\
\hline Data accessibility & Flickr \\
\hline
\end{tabular}

Data from the photo sharing website Flickr is freely available online and has high potential for the assessment of cultural ES. Original images were uploaded to Flickr by users, often preserving the geographic location of where the photo was taken. The photo locations can thus be used an indication of cultural ES, especially outdoor recreation. The data consists of the number of images that were uploaded within the grassland category between the years of 2008 and 2017 to Flickr for the study area of Solothurn, Switzerland.

The grasslands shapefile was projected from CH1903+_LV95 to GCS_WGS 1984 using the CH1903+_LV95_To_GCS_WGS_1984 geographic transformation in ArcMap v10.3. A python script 
was run to query the Flickr API at every $0.01 \times 0.01$ degree, capturing all points. The points were imported in ArcMap and used calculate points within each grassland and elevation types (with a 100m buffer) by year (between 2008-2017). Multiple buffer sizes between $25 \mathrm{~m}$ and $150 \mathrm{~m}$ were tested, before $100 \mathrm{~m}$ was chosen, following Haider and Ali (2018), as they previously used this radius to gather Flickr data around the location of sites for assessment for cultural service assessment (specifically aesthetic). The number of resulting photos per $\mathrm{km}^{2}$ were calculated using the original area covered by each grassland category, rather than the buffer area. A total of 17,979 photos were analyzed in this analysis. See Table A1.

Table A1: Photos by grassland category $\left(\mathrm{per} \mathrm{km}^{2}\right)$ by year. Calculated using a $100 \mathrm{~m}$ buffer, with area calculation using original area size of each grassland category and two elevation levels. Lowlands are considered as grasslands below 800 masl and highlands as grasslands above 800 masl.

\begin{tabular}{|c|c|c|c|c|c|c|c|c|c|c|c|c|c|c|c|c|c|c|}
\hline Intensity & Elevation & 2008 & 2009 & \multicolumn{2}{|c|}{2010} & \multicolumn{2}{|c|}{2011} & \multicolumn{2}{|c|}{2012} & \multicolumn{2}{|c|}{2013} & \multicolumn{2}{|c|}{2014} & \multicolumn{2}{|c|}{2015} & \multicolumn{2}{|r|}{2016} & 2017 \\
\hline \multicolumn{19}{|l|}{ Meadow } \\
\hline \multirow{2}{*}{ Intensive } & Lowland & 3.64 & 5.06 & \multicolumn{2}{|r|}{1.95} & 4.2 & & \multicolumn{2}{|c|}{3.74} & \multicolumn{2}{|c|}{6.18} & 9.54 & & \multicolumn{2}{|c|}{15.61} & \multicolumn{2}{|c|}{7.35} & 6.64 \\
\hline & Highland & 9.04 & 2.13 & \multicolumn{2}{|r|}{1.15} & 0.7 & & \multicolumn{2}{|c|}{1.06} & \multicolumn{2}{|c|}{10.81} & 5.14 & & \multicolumn{2}{|c|}{9.31} & \multicolumn{2}{|c|}{3.72} & 5.41 \\
\hline \multirow{2}{*}{ Less intensive } & Lowland & 1.75 & 2.28 & \multicolumn{2}{|r|}{2.46} & 1.4 & & \multicolumn{2}{|l|}{1.23} & \multicolumn{2}{|c|}{2.10} & 7.72 & & \multicolumn{2}{|c|}{7.37} & \multicolumn{2}{|c|}{2.81} & 3.33 \\
\hline & Highland & 6.72 & 8.39 & \multicolumn{2}{|r|}{0.00} & 0.0 & & \multicolumn{2}{|c|}{5.04} & \multicolumn{2}{|c|}{0.00} & 5.04 & & & 36 & & 00 & 5.04 \\
\hline & Lowland & 4.15 & 3.21 & & 1.94 & 4.2 & & 3.29 & & 5.3 & & 8.29 & & 11 & & & 49 & 6.64 \\
\hline Extensive & Highland & 0.88 & 5.97 & & 2.46 & 2.8 & & 4.74 & & 3.16 & & 5.44 & & 10 & & & 86 & 7.20 \\
\hline Pasture & & & & & & & & & & & & & & & & & & \\
\hline & Lowland & & & 3.92 & & & & 89 & 2. & & 6. & 35 & & 57 & & & 2.83 & 3.85 \\
\hline Intensive & Highland & & & 1.47 & & & & 00 & 2. & & 4. & 00 & & 93 & 20 & & 2.93 & 36.66 \\
\hline Evton & Lowland & & & 3.30 & & & & 71 & 2. & & 7.8 & 83 & & 24 & & & 2.68 & 11.06 \\
\hline Extensive & Highland & $\overline{14}$ & & 6.40 & 12 & & & 77 & 37. & & 13. & & & & & & 2.83 & 7.91 \\
\hline
\end{tabular}

\section{Appendix 2: Description of the grasslands and the explanatory variables}

Characteristics of the management (regime and intensity levels)

Parcels are varied in terms of management and environmental characteristics (Table A2). Census data were acquired from the Canton of Solothurn (http://gelan.ch) and are publically available. The data set provides georeferenced information across the Canton about the location of the parcels and some of their management characteristics, i.e., management regime and the level of intensity of their management. Moreover, the information has been validated by the farmers and is being used to distribute potential direct payments. We selected parcels of grasslands only.

The census data classify grasslands into five classes, based on their management: two regimes (pasture and meadow) and two to three intensity levels (intensive, less intensive and extensive meadows and intensive and extensive pastures). We used scientific literature to further characterize these five classes, according to their management (Blüthgen et al., 2012), e.g. in terms of amount of fertilizer, frequency of mowing or grazing. Here, we defined meadows as grasslands that are harvested predominantly by mowing over the last years or since sward establishment if it is younger than five years (Peeters et al., 2014). In agreement with the census set, meadows were divided into three levels of intensity: intensive, less intensive and extensive. Pastures were defined as grasslands that have been predominantly grazed over the last five years or since sward establishment if it is younger than five years. In concordance with the census database, we distinguished intensive from extensive pastures. We assumed that grasslands are well-balanced in species composition (i.e. they comprise 50 to $70 \%$ of grass; Huguenin-Elie al., 2017). The use of these two parameters (management regime and management intensity) resulted in the establishment of five grassland categories (Table A2). 
Elevation affects various variables related to environmental characteristics (e.g. species richness, productivity) and to management intensity (e.g. yield, number of cuts; (Bergamini et al., 2001; Bühler and Schmid, 2001; Grandchamp et al., 2005; Güsewell et al., 2012; Jacot et al., 2000). We decided to distinguish two elevational classes. Despite an abundant literature, there is no consensus on thresholds to delimit elevational class. Based on previous studies, biogeographical knowledge and taking into account statistical constraints related to the need for a minimum number of observations per class, we decided to differentiate two elevational classes: lowlands (<800m m.a.s.l.) and highlands (> $800 \mathrm{~m}$ m.a.s.I.). We used this further distinction between grassland categories to model the recreational service.

Table A2. Distribution of the grasslands categories. In the lowland, many intensive meadows are not permanent grasslands but are included in a system of crop rotation and therefore we did not include these rotational meadows. When applicable, in brackets, the range of the values of the variables.

\begin{tabular}{|l|l|l|l|l|l|}
\hline & \multicolumn{2}{l|}{ Meadows } & \multicolumn{2}{l|}{ Pasture } \\
\hline & Extensive & Less intensive & Intensive & Extensive & Intensive \\
\hline Number of parcels & 6462 & 312 & 6900 & 1137 & 2572 \\
\hline Area (ha) & $\begin{array}{l}3350 \quad(0.001- \\
9.6)\end{array}$ & $156(0.001-96)$ & $\begin{array}{l}6647 \\
21.1)\end{array}$ & $\begin{array}{l}1562 \\
25.9)\end{array}$ & $\begin{array}{l}3764 \\
23.1)\end{array}$ \\
\hline Elevation (m) & $556(324-1351)$ & $\begin{array}{l}585 \quad(349- \\
1269)\end{array}$ & $594(305-1373)$ & $705(335-1370)$ & $619(325-1373)$ \\
\hline Slope (\%) & $13(0-87)$ & $15(0-56)$ & $15(0-87)$ & $24(0-75)$ & $17(0-77)$ \\
\hline Distance to the forest (m) & $226(0-2300)$ & $120(0-985)$ & $166(0-2336)$ & $93(0-2234)$ & $165(0-2266)$ \\
\hline $\begin{array}{l}\text { Main class of soil suitabil- } \\
\text { ity }\end{array}$ & 1 & 4 & 4 & 5 & 5 \\
\hline
\end{tabular}

Environmental characterization of the parcels and their surrounding landscape in the canton of Solothurn

The parcels of grasslands are georeferenced. Therefore, in a GIS, it is possible to calculate their area and to overlay their limits with other environmental variables to characterize the biophysical attributes of each parcel and its surrounding landscape (Table A3). To characterize the parcels, we used information related to topography (Aster DEM, available on https://gdex.cr.usgs.gov/gdex/). We calculated average elevation and slope, using the ArcGIS Spatial Analysis toolbox. We also used the soil classification (FOAG, 2005) to determine the dominant soil class. Landscape characteristics, distance to forests, Simpson's diversity and patch richness (metrics of landscape structure), were calculated from Corine Land Cover (available on https://land.copernicus.eu/pan-european/corine-landcover/clc-2012/view).

Table A3. Characterization of the parcels of Solothurn, based on their environmental attributes and on the surrounding landscape (example of 20 parcels).

\begin{tabular}{|c|c|c|c|c|c|c|c|c|}
\hline Regime & Intensity & $\begin{array}{c}\text { Soil } \\
\text { suitability }\end{array}$ & $\begin{array}{c}\text { Slope } \\
(\%)\end{array}$ & $\begin{array}{c}\text { Elevation } \\
\text { (m) }\end{array}$ & $\begin{array}{c}\text { Parcel } \\
\text { Area (ha) }\end{array}$ & $\begin{array}{c}\text { Distance } \\
\text { to forest (m) }\end{array}$ & $\begin{array}{l}\text { Simpson } \\
\text { Diversity }\end{array}$ & $\begin{array}{c}\text { Patch } \\
\text { Richness }\end{array}$ \\
\hline Pasture & Extensive & 1 & 6 & 404 & 2.47 & 918.65 & 0 & 1 \\
\hline Meadow & Extensive & 1 & 3 & 467 & 0.19 & 1215.46 & 0 & 1 \\
\hline Meadow & Intensive & 5 & 20 & 972 & 5.35 & 443.54 & 0.26 & 2 \\
\hline Meadow & Extensive & 3 & 6 & 479 & 1.00 & 1114.96 & 0 & 1 \\
\hline Meadow & Extensive & 2 & 19 & 398 & 0.26 & 128.77 & 0.18 & 3 \\
\hline Meadow & Extensive & 1 & 2 & 434 & 1.20 & 1632.10 & 0.27 & 2 \\
\hline Meadow & Intensive & 2 & 8 & 630 & 0.55 & 806.07 & 0.23 & 2 \\
\hline Meadow & Extensive & 3 & 2 & 436 & 0.26 & 1713.24 & 0.16 & 2 \\
\hline Meadow & Intensive & 1 & 12 & 499 & 0.64 & 238.72 & 0.00 & 1 \\
\hline Pasture & Intensive & 5 & 8 & 626 & 0.26 & 68.19 & 0 & 1 \\
\hline
\end{tabular}




\begin{tabular}{|c|c|c|c|c|c|c|c|c|}
\hline Meadow & Intensive & 4 & 5 & 643 & 0.08 & 1985.28 & 0.43 & 2 \\
\hline Meadow & Extensive & 1 & 5 & 460 & 0.09 & 1511.53 & 0.43 & 2 \\
\hline Pasture & Intensive & 5 & 7 & 469 & 0.59 & 2051.49 & 0.00 & 1 \\
\hline Meadow & Intensive & 5 & 10 & 590 & 0.09 & 1359.37 & 0.43 & 2 \\
\hline Meadow & Intensive & 4 & 8 & 500 & 0.72 & 881.82 & 0.12 & 2 \\
\hline Meadow & Less Intensive & 4 & 6 & 479 & 0.01 & 15.17 & 0.24 & 2 \\
\hline Meadow & Intensive & 2 & 2 & 460 & 1.09 & 634.54 & 0.16 & 2 \\
\hline Meadow & Intensive & 3 & 5 & 699 & 1.80 & 968.27 & 0 & 1 \\
\hline Meadow & Extensive & 1 & 3 & 476 & 0.24 & 2458.71 & 0.25 & 2 \\
\hline Meadow & Extensive & 3 & 7 & 668 & 0.20 & 698.75 & 0. & 1 \\
\hline
\end{tabular}

\section{Appendix 3: $\mathrm{C}$ in fertilization}

To calculate the $C$ in fertilizers ( $C$ imported in the system), we first estimated the amounts of fertilizers applied on each parcel. We used the recommended amounts of nitrogen fertilizers presented in Huguenin-Elie et al. (2017) for each of the grassland categories (management regime * intensity) and per unit of yield. $\mathrm{N}$ fertilization recommendations ranged from 1.1 to $1.3 \mathrm{~kg} \mathrm{~N} / \mathrm{dt} \mathrm{DM}$ for intensive grasslands (meadows or pastures) and from 0.4 to $0.6 \mathrm{~kg} \mathrm{~N} / \mathrm{dt} \mathrm{DM}$ for less intensive meadows. Extensive grasslands are not fertilized at all in Switzerland. For each parcel, we thus multiplied the yield by the recommended amount of $\mathrm{N}$ fertilizer. Then, we applied the ratio $\mathrm{C} / \mathrm{N}$ of 2.1 to reveal the amount of $\mathrm{C}$ contained in the organic fertilization. The $\mathrm{C} / \mathrm{N}$ ratio was estimated from the data available from for two observation sites used to model the NEE (Chamau and Früebüel; Swiss flux towers).

\section{Appendix 4: Additional results from the statistical and spatial modelling}

Summary statistics of ES variables with management regime and intensity levels

The calculation of grassland ES for different grasslands categories showed the variation between regimes and intensity levels derived from empirical datasets (Table A4).

Table A4. Variations in measured ES indicators within the intensity levels of both meadows and pastures. We displayed the statistics for the time series of the indicator of outdoor recreation (number of pictures).

\begin{tabular}{|c|c|c|c|c|c|c|}
\hline & & \multicolumn{3}{|c|}{ Meadow } & \multicolumn{2}{|c|}{ Pasture } \\
\hline & & Intensive & Less intensive & Extensive & Intensive & Extensive \\
\hline \multirow{6}{*}{$\begin{array}{l}\text { Yield } \\
\text { t/ha }\end{array}$} & Min & 6.37 & 3.15 & 1.42 & 5.66 & 1.11 \\
\hline & Median & 10.61 & 5.35 & 2.69 & 9.01 & 1.81 \\
\hline & Mean & 10.84 & 5.32 & 2.64 & 9.15 & 1.82 \\
\hline & Max & 13 & 6.4 & 3.05 & 11 & 2.4 \\
\hline & Standard deviation & 1.34 & 0.67 & 0.33 & 1.28 & 0.29 \\
\hline & Observations* & 6411 & 303 & 5992 & 2433 & 1100 \\
\hline \multirow{6}{*}{$\begin{array}{l}\text { C exchange } \\
\text { t C/(ha * year) }\end{array}$} & Min & -1.7 & -5.1 & -2.8 & -4.3 & -4.4 \\
\hline & Median & -0.8 & -0.9 & -1.7 & -2.4 & -1.2 \\
\hline & Mean & -0.5 & -1.3 & -1.7 & -2.5 & -1.4 \\
\hline & Max & 1.4 & 0.2 & -0.2 & -0.8 & 1 \\
\hline & Standard deviation & 1.1 & 1.7 & 0.7 & 0.9 & 1.6 \\
\hline & Observations & 13 & 16 & 18 & 19 & 17 \\
\hline \multirow{6}{*}{$\begin{array}{l}\text { Bee species } \\
\text { richness } \\
\text { (number) }\end{array}$} & Min & 1 & 3 & 2 & 3 & 7 \\
\hline & Median & 3 & 4 & 5 & 3.5 & 7.5 \\
\hline & Mean & 3.6 & 4.8 & 5.1 & 4.0 & 7.5 \\
\hline & Max & 7 & 7 & 7 & 6 & 8 \\
\hline & Standard deviation & 1.6 & 1.5 & 1.6 & 1.26 & 0.58 \\
\hline & Observations & 17 & 11 & 12 & 6 & 7 \\
\hline \multirow{2}{*}{$\begin{array}{l}\text { Plant species } \\
\text { richness }\end{array}$} & Min & 22 & 29 & 36 & 20 & 44 \\
\hline & Median & 26 & 38 & 48 & 32 & 46 \\
\hline
\end{tabular}




\begin{tabular}{|l|l|ccc|cc|} 
(number) & Mean & $\mathbf{2 7 . 4}$ & $\mathbf{3 8 . 5}$ & $\mathbf{4 9 . 8}$ & $\mathbf{3 0 . 2}$ & $\mathbf{4 8 . 4}$ \\
& Max & 35 & 50 & 70 & 38 & 57 \\
& Standard deviation & 4.2 & 6.7 & 9 & 6.9 & 5.3 \\
\cline { 2 - 8 } & Observations & 17 & 11 & 12 & 6 & 7 \\
\hline \multirow{4}{*}{ Number of } & Min & 0.71 & 0.63 & 0.91 & 1.17 & 2.23 \\
photos & Median & 8.31 & 4.2 & 6.82 & 4.39 & 7.02 \\
& Mean & $\mathbf{8 . 4 1}$ & $\mathbf{4 . 3 1}$ & $\mathbf{6 . 8 1}$ & $\mathbf{8 . 0 8}$ & $\mathbf{5 . 5 7}$ \\
& Max & 15.6 & 7.66 & 12.43 & 36.49 & 37.03 \\
& Standard deviation & 3.93 & 1.88 & 2.86 & 5.62 & 5.29 \\
\cline { 2 - 8 } & Observations & 20 & 20 & 20 & 20 & 20 \\
\hline
\end{tabular}

*Because yield data were not measured on the field, the statistics summary for this ES was calculated for the grasslands of Solothurn.

\section{Summary of the final models}

To model the $\mathrm{C}$ sequestration, we first built a linear model based on $\mathrm{CO}_{2}$ flux data collected at flux towers in temperate grassland sites across Europe to estimate the net exchange $N E E_{p}$ (Eq. 1a). We selected the final model, through a variable selection procedure and estimated the parameters.

$N E E=\propto_{0}+\propto_{1} \cdot$ Regime $+\propto_{2} \cdot$ Intensity $+\propto_{3} \cdot$ Elevation $+\propto_{4} \cdot($ Intensity $\cdot$ Elevation $)$

Multiple $\mathrm{R}^{2}$ : 0.40; Adjusted $\mathrm{R}^{2}: 0.35 ;$-value: $<0.001$

\begin{tabular}{|l|l|}
\hline Coefficients $(\propto)$ : & Estimate \\
\hline (Intercept) & -0.7906 \\
\hline Regime-Pasture & -0.1441 \\
\hline Elevation & -0.0018 \\
\hline Intensity-Intensive & 0.1414 \\
\hline Intensity-Less Intensive & -3.602 \\
\hline Elevation: Intensity-Intensive & 0.0001 \\
\hline Elevation: Intensity-Less Intensive & 0.0043 \\
\hline
\end{tabular}

We also estimated the $C$ exported from the grassland systems ( $C_{\text {export }}$ through harvesting; Eq.1d for pastures) for each parcel.

$C_{\text {export }}=-0.01+0.41 \cdot$ Yield

Multiple $\mathrm{R}^{2}$ : 0.99; Adjusted $\mathrm{R}^{2}$ : 0.99; $p$-value: $<0.001$

\begin{tabular}{|l|l|}
\hline Coefficients $(\partial):$ & Estimate \\
\hline (Intercept) & -0.01146 \\
\hline Yield & 0.409002 \\
\hline
\end{tabular}

Vascular plant and bee species richness

We implemented regression analyses to model bee and vascular plant species richness (Eq. 2).

Species richness $=\gamma_{0}+\gamma_{X} \cdot X$,

with Species richness, the richness in either bees or plants, $X$ a set of explanatory variables about the management, its environmental characteristics and the characteristics of the surrounding landscape of a specific parcel.

The final model for the bees presented the following variables:

Bee Species Richness $=\gamma_{0}+\gamma_{1} \cdot$ Regime $+\gamma_{2} \cdot$ INtensity $+\gamma_{3} \cdot$ Distance to the forest $+\gamma_{4} \cdot$ Slope

Multiple $\mathrm{R}^{2}$ : 0.41; Adjusted $\mathrm{R}^{2}: 0.35 ; p$-value: $<0.001$ 


\begin{tabular}{|l|l|}
\hline Coefficients (y): & \multicolumn{1}{c|}{ Estimate } \\
\hline (Intercept) & 7.658406 \\
\hline Regime-pasture & 1.139367 \\
\hline Intensity-Intensive & -1.243324 \\
\hline Intensity-Less Intensive & -0.079226 \\
\hline Distance to forest & -0.003152 \\
\hline Slope & -0.108794 \\
\hline
\end{tabular}

The final model for the vascular plants presented the following variables:

Plant Species Richness $=\gamma_{0}^{\prime}+\gamma_{11} \cdot$ Regime $+\gamma_{2}^{\prime} \cdot$ Intensity $+\gamma_{3}^{\prime} \cdot$ Elevation $+\gamma_{4}^{\prime} \cdot$ Slope

Multiple $\mathrm{R}^{2}$ : 0.75; Adjusted $\mathrm{R}^{2}: 0.72 ; p$-value: $<0.001$

\begin{tabular}{|l|l|}
\hline Coefficients ( $\left.\mathbf{Y}^{\prime}\right):$ & \multicolumn{1}{c|}{ Estimate } \\
\hline (Intercept) & 62.592872 \\
\hline RegimePasture & 3.186714 \\
\hline IntensityIntensive & -18.651679 \\
\hline IntensityLess Intensive & -7.149257 \\
\hline Elevation & -0.015758 \\
\hline Slope & -0.187069 \\
\hline
\end{tabular}

Maps of the ES indicators

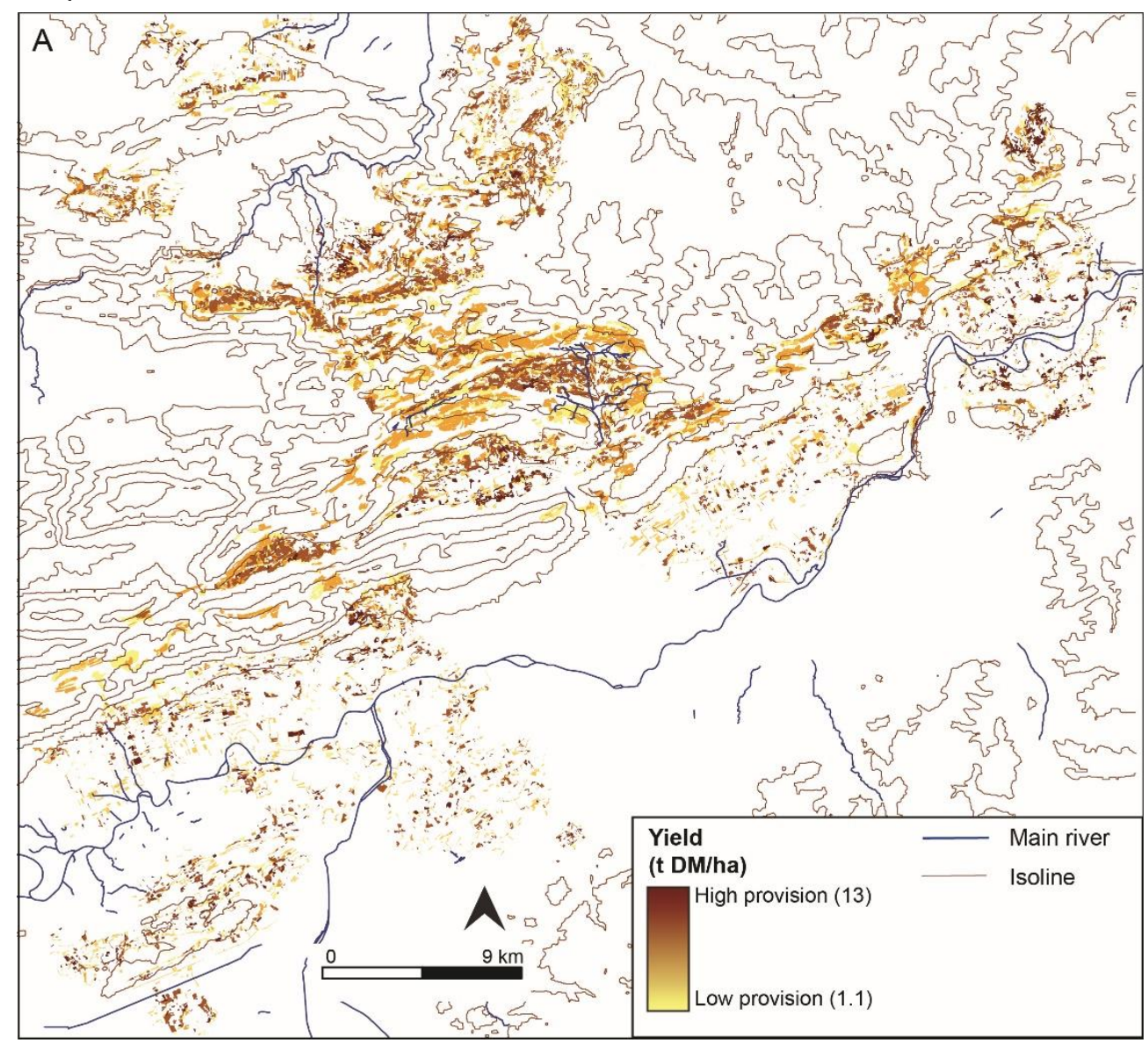



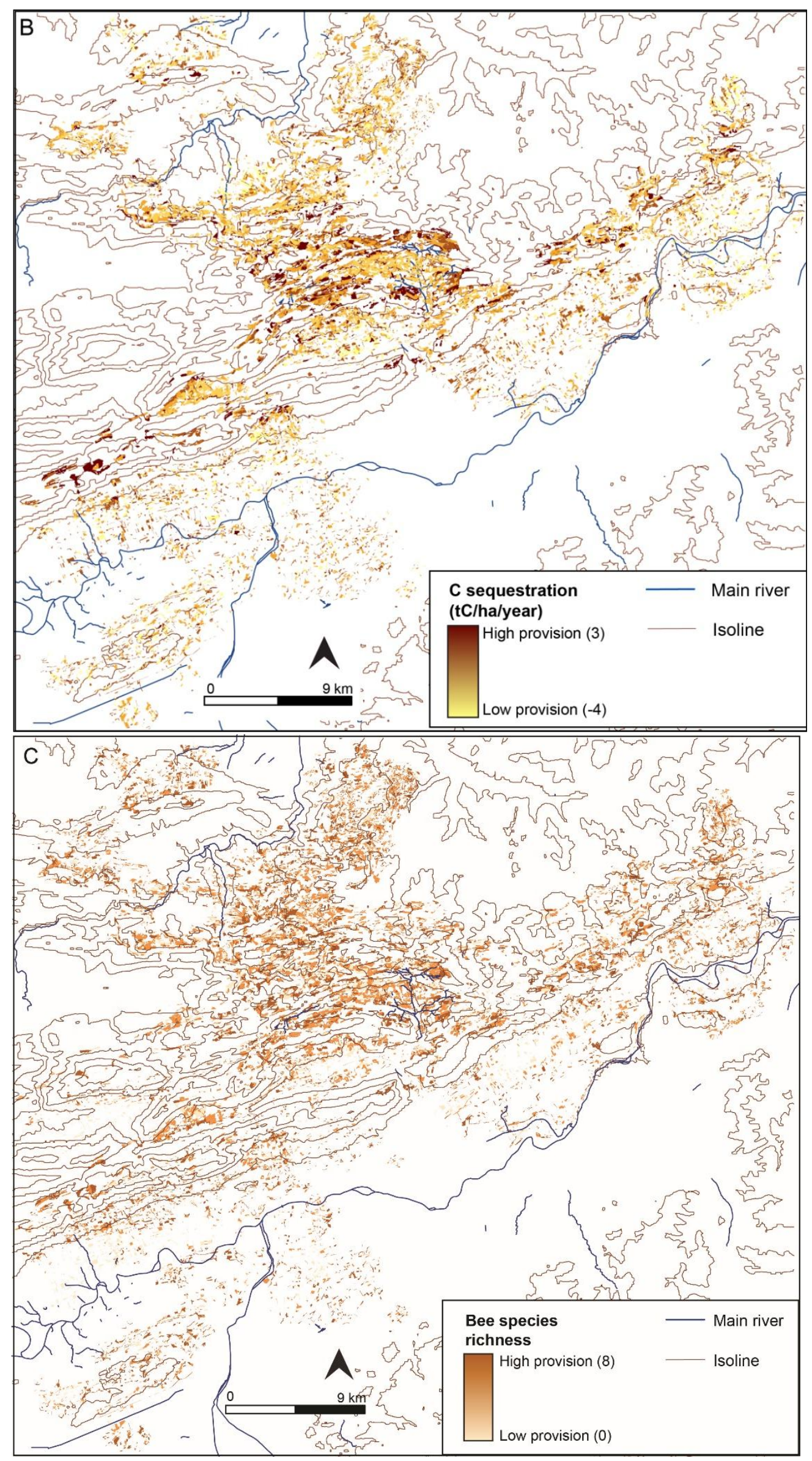


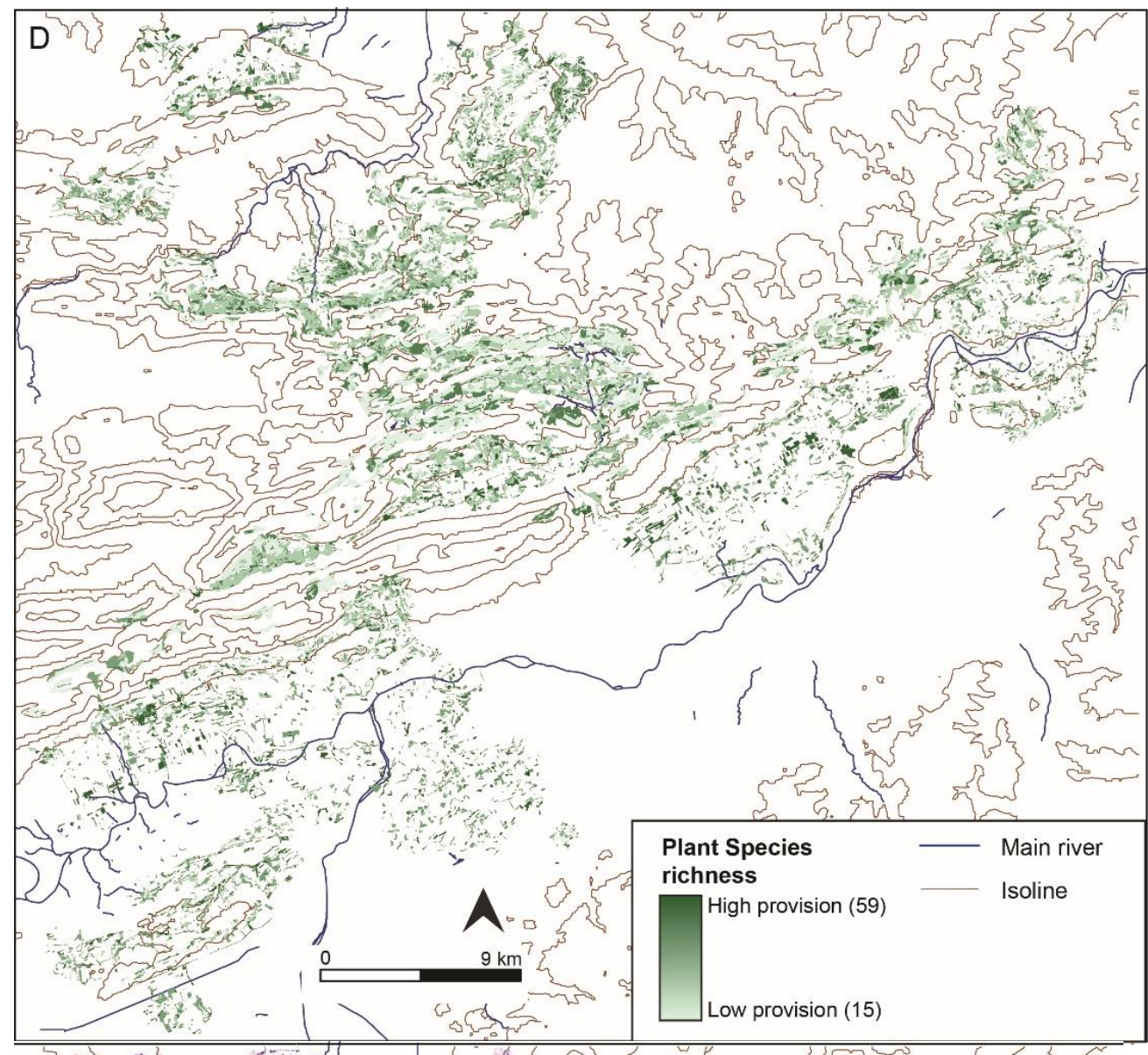

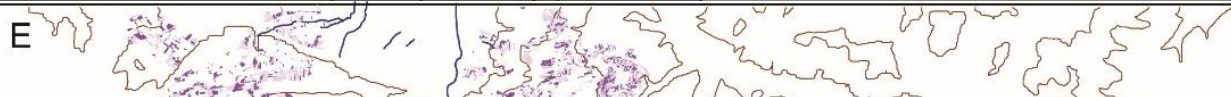

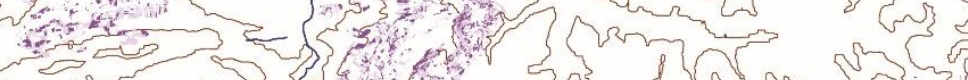

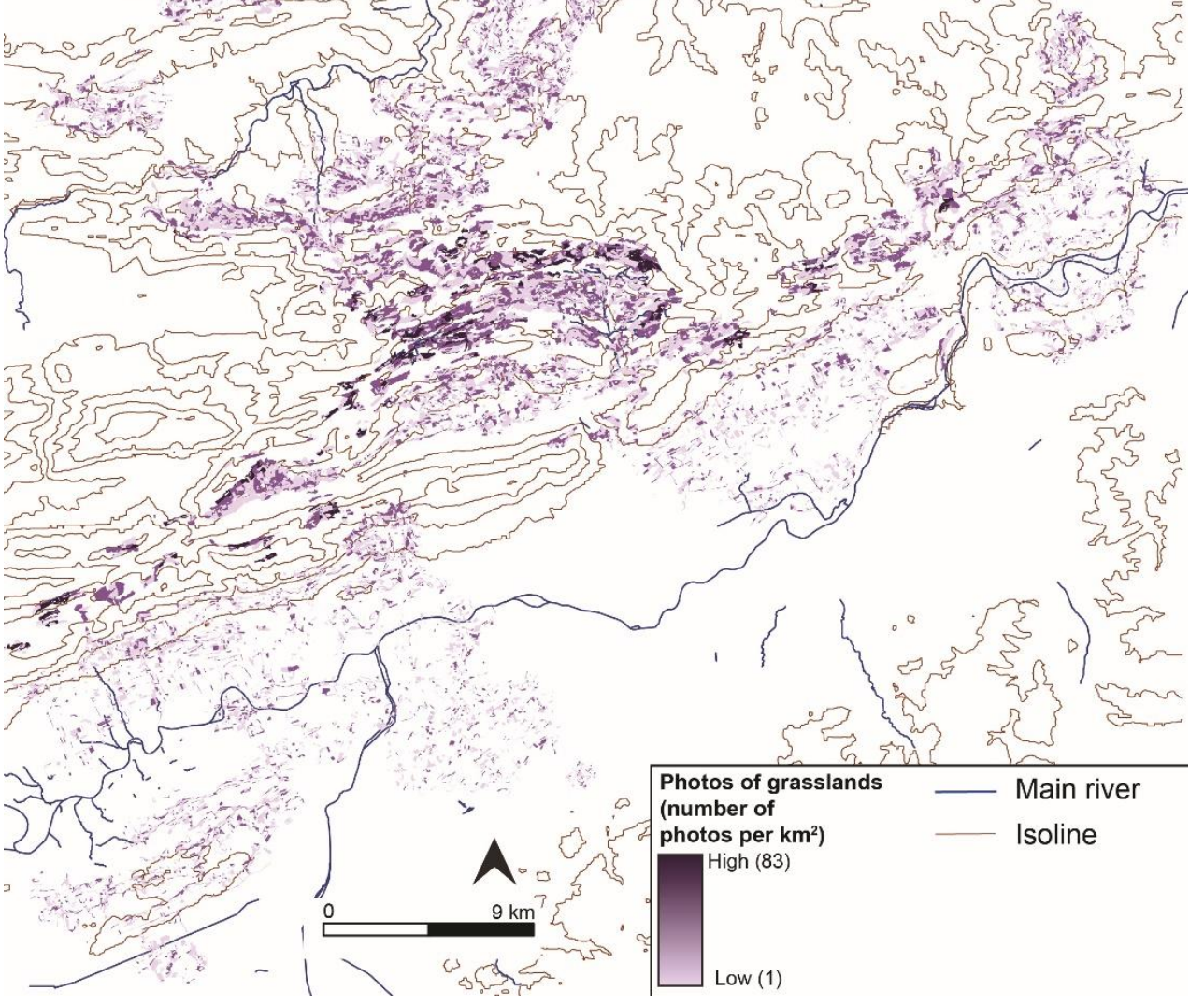


Figure A1. Spatial distribution of the ES in Solothurn. A. Yield; B. C sequestration. Positive values reveal C sinks whereas negative values indicate $C$ sources; $C$. Bee species richness; $D$. Plant species richness and $E$. Number of photos. In brackets, lowest and highest value of the ES provision.

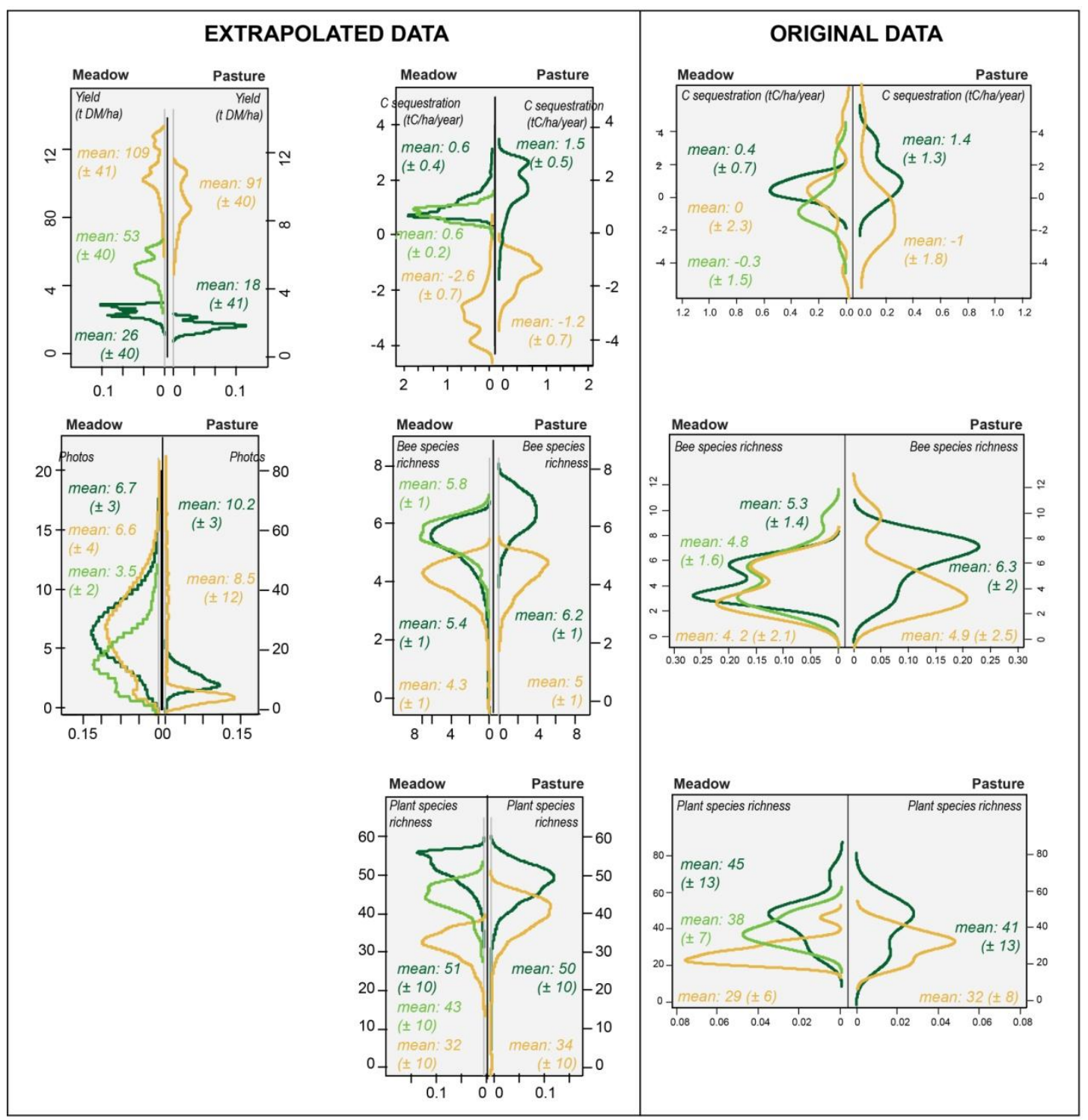

Figure A2. Density functions demonstrate the probability of the expected ES provision under a specific management.

Table A6. Results of the Kruskall-Wallis tests

\begin{tabular}{|l|l|l|}
\hline \multirow{2}{*}{} & \multicolumn{2}{|c|}{ Kruskall-Wallis } \\
\cline { 2 - 3 } & Chi-squared & p-value \\
\hline Yield & 14251 & $<0.001$ \\
\hline C sequestration & 14870 & $<0.001$ \\
\hline Bee species richness & 8249.7 & $<0.001$ \\
\hline Plant species richness & 13217 & $<0.001$ \\
\hline Number of photos & 1926 & $<0.001$ \\
\hline
\end{tabular}

\section{Appendix 4: Additional results on multiple ES assessment}

Table A7. Correlation table (Pearson's correlations) between the five modelled ES, for meadows and pastures.

\begin{tabular}{|l|l|l|l|l|l|}
\hline MEADOW & Yield & C sequestration & Bee spe- & Plant spe- & Number of \\
\hline
\end{tabular}




\begin{tabular}{|c|c|c|c|c|c|}
\hline & & & $\begin{array}{l}\text { cies rich- } \\
\text { ness }\end{array}$ & $\begin{array}{l}\text { cies rich- } \\
\text { ness }\end{array}$ & photos \\
\hline Forage provision & 1 & & & & \\
\hline C sequestration & -0.99 & 1 & & & \\
\hline Pollination & -0.55 & 0.56 & 1 & & \\
\hline Biodiversity & -0.85 & 0.77 & 0.49 & 1 & \\
\hline Recreation & -0.01 & 0.01 & 0 & 0.02 & 1 \\
\hline PASTURE & Yield & C sequestration & $\begin{array}{l}\text { Bee spe- } \\
\text { cies rich- } \\
\text { ness }\end{array}$ & $\begin{array}{l}\text { Plant spe- } \\
\text { cies rich- } \\
\text { ness }\end{array}$ & $\begin{array}{l}\text { Number of } \\
\text { photos }\end{array}$ \\
\hline Forage provision & 1 & & & & \\
\hline C sequestration & -0.98 & 1 & & & \\
\hline Pollination & -0.58 & 0.55 & 1 & & \\
\hline Biodiversity & -0.70 & 0.56 & 0.58 & 1 & \\
\hline Recreation & -0.24 & 0.33 & 0.01 & -0.20 & 1 \\
\hline
\end{tabular}

Table A8. ES overall score within the grassland categories, for all parcels of agricultural grasslands of the Canton of Solothurn.

\begin{tabular}{|l|l|l|l|l|l|}
\hline & & \multicolumn{4}{|l|}{ ES score } \\
\hline Regime & Intensity level & Min & Max & Mean & Standard deviation \\
\hline \multirow{3}{*}{ Meadow } & Intensive & 8 & 16 & 12 & 1.5 \\
\cline { 2 - 7 } & Less Intensive & 8 & 16 & 12 & 1.6 \\
\cline { 2 - 6 } & Extensive & 9 & 18 & 13 & 1.6 \\
\hline \multirow{3}{*}{ Pasture } & Intensive & 8 & 16 & 12 & 1.4 \\
\cline { 2 - 6 } & Extensive & 10 & 17 & 14 & 1.1 \\
\hline
\end{tabular}

\section{References}

Bergamini, A., Peintinger, M., Schmid, B., Urmi, E., 2001. Effects of management and altitude on bryophyte species diversity and composition in montane calcareous fens. Flora 196, 180-193.

Blüthgen, N., Dormann, C., Prati, D., Klaus, V., Kleinebecker, T., Hölzel, N., Alt, F., Boch, S., Gockel, S., Hemp, A., Müller, J., Nieschulze, J., Renner, S., Schöning, I., Schumacher, U., Socher, S., Wells, K., Birkhofer, K., Buscot, F., Oelmann, Y., Rothenwöhrer, C., Scherber, C., Tscharntke, T., Weiner, C., Fischer, M., Kalko, E., Linsenmair, K., Schulze, E., Weisser, W., 2012. A quantitative index of land-use intensity in grasslands: Integrating mowing, grazing and fertilization. Basic and Applied Ecology 13, 207-220.

Bühler, C., Schmid, B., 2001. The Influence of Management Regime and Altitude on the Population Structure of Succisa pratensis: Implications for Vegetation Monitoring. Journal of Applied Ecology 38, 689-698.

Dennis, P., Bogers, M.M.B., Bunce, R.G.H., Herzog, F., Jeanneret, P., Geijzendorffer, I.R., Jongman, R.H.G., 2012. Biodiversity in organic and low-input farming systems : handbook for recording key indicators. Alterra, Wageningen-UR, Wageningen.

FOAG, 2005. Cartes des aptitudes des sols de la Suisse.

Grandchamp, A.-C., Bergamini, A., Stofer, S., Niemelä, J., Duelli, P., Scheidegger, C., 2005. The influence of grassland management on ground beetles (Carabidae, Coleoptera) in Swiss montane meadows. Agriculture, Ecosystems \& Environment 110, 307-317.

Güsewell, S., Peter, M., Birrer, S., 2012. Altitude modifies species richness-nutrient indicator value relationships in a country-wide survey of grassland vegetation. Ecological Indicators 20, 134-142. Haider, C.M.R., Ali, M.E., 2018. Can We Predict the Scenic Beauty of Locations from Geo-tagged Flickr Images?, 23rd International Conference on Intelligent User Interfaces. ACM, Tokyo, Japan, pp. 653657.

Huguenin-Elie, O., Mosimann, E., Schlegel, P., Lüscher, A., Kessler, W., Jeangros, B., 2017. Fertilisation des herbages. Recherche agronomique Suisse 8, 143-165. 
Jacot, K.A., Lüscher, A., Nösberger, J., Hartwig, U.A., 2000. Symbiotic N2 fixation of various legume species along an altitudinal gradient in the Swiss Alps. Soil Biology and Biochemistry 32, 1043-1052. Lüscher, G., Ammari, Y., Andriets, A., Angelova, S., Arndorfer, M., Bailey, D., Balázs, K., Bogers, M., Bunce, R.G.H., Choisis, J.-P., Dennis, P., Díaz, M., Dyman, T., Eiter, S., Fjellstad, W., Fraser, M., Friedel, J.K., Garchi, S., Geijzendorffer, I.R., Gomiero, T., González-Bornay, G., Guteva, Y., Herzog, F., Jeanneret, P., Jongman, R.H.G., Kainz, M., Kwikiriza, N., López Díaz, M.L., Moreno, G., NicholasDavies, P., Nkwiine, C., Opio, J., Paoletti, M.G., Podmaniczky, L., Pointereau, P., Pulido, F., Sarthou, J.P., Schneider, M.K., Sghaier, T., Siebrecht, N., Stoyanova, S., Wolfrum, S., Yashchenko, S., Albrecht, H., Báldi, A., Belényesi, M., Benhadi-Marin, J., Blick, T., Buholzer, S., Centeri, C., Choisis, N., Cuendet, G., De Lange, H.J., Déjean, S., Deltshev, C., Díaz Cosín, D.J., Dramstad, W., Elek, Z., Engan, G., Evtushenko, K., Falusi, E., Finch, O.-D., Frank, T., Gavinelli, F., Genoud, D., Gillingham, P.K., Grónás, V., Gutiérrez, M., Häusler, W., Heer, X., Hübner, T., Isaia, M., Jerkovich, G., Jesus, J.B., Kakudidi, E., Kelemen, E., Koncz, N., Kovacs, E., Kovács-Hostyánszki, A., Last, L., Ljubomirov, T., Mandery, K., Mayr, J., Mjelde, A., Muster, C., Nascimbene, J., Neumayer, J., Ødegaard, F., Ortiz Sánchez, F.J., Oschatz, M.L., Papaja-Hülsbergen, S., Paschetta, M., Pavett, M., Pelosi, C., Penksza, K., Pommeresche, R., Popov, V., Radchenko, V., Richner, N., Riedel, S., Scullion, J., Sommaggio, D., Szalkovszki, O., Szerencsits, E., Trigo, D., Vale, J., van Kats, R., Vasilev, A., Whittington, A.E., Wilkes-Allemann, J., Zanetti, T., 2016. Farmland biodiversity and agricultural management on 237 farms in 13 European and two African regions. Ecology 97, 1625-1625.

Peeters, A., Beaufoy, G., Canals, R.M., De Vliegher, A., Huyghe, C., Isselstein, J., Jones, G., Kessler, W., Kirilov, A., Mosquera Losada, M.R., Nilsdotter-Linde, N., Parente, G., Peyraud, J.-L., Pickert, J., Plantureux, S., Porqueddu, C., Rataj, D., Stypinski, P., Tonn, B., van del Pol-van Dasselaar, A., Vintu, V., Wilkins, R.J., 2014. Grassland term definitions and classifications adapted to the diversity of European grassland-based systems, 25. General Meeting of the European Grassland Federation. Institute of Biological, Environmental and Rural Sciences (IBERS), Aberystwyth, United Kingdom, p. $897 \mathrm{p}$. 